\title{
The Fate of Agent Blue, the Arsenic Based Herbicide, Used in South Vietnam during the Vietnam War
}

\author{
Kenneth R. Olson1, Larry Cihacek ${ }^{2}$ \\ ${ }^{1}$ Department of Natural Resources and Environmental Sciences, College of Agriculture and Environmental Sciences, University of \\ Illinois, Urbana, Illinois, USA \\ ${ }^{2}$ School of Natural Resources, North Dakota State University, Fargo, North Dakota, USA \\ Email: krolson@illinois.edu
}

How to cite this paper: Olson, K.R. and Cihacek, L. (2020) The Fate of Agent Blue, the Arsenic Based Herbicide, Used in South Vietnam during the Vietnam War. Open Journal of Soil Science, 10, 518-577. https://doi.org/10.4236/ojss.2020.1011027

Received: November 2, 2020

Accepted: November 27, 2020

Published: November 30, 2020

Copyright $\odot 2020$ by author(s) and Scientific Research Publishing Inc. This work is licensed under the Creative Commons Attribution International License (CC BY 4.0).

http://creativecommons.org/licenses/by/4.0/ (c) (i) Open Access

\begin{abstract}
The destruction of the South Vietnamese rice (Oryza sativa $L$ ) crop using an arsenic-based herbicide known as Agent Blue during the American Vietnam War (1965-1972) was not a secret; however, it received little media attention in the United States. Republic of Vietnam and United States (U.S.) militaries began destroying food crops (rice) in November of 1962 primarily via aerial applications in the Mekong Delta and Central Highlands of South Vietnam. Spraying of Agent Blue on 100,000 ha of mangrove forests and about 300,000 ha of rice paddies just before rice harvest time resulted in the destruction of the standing crop and rendered the land contaminated with arsenic (As). Six Rainbow herbicides, commonly called Agent Orange, Agent Green, Agent Pink, Agent Purple, Agent White, and Agent Blue, were sprayed on wetlands, rice paddies, forests, mangroves, bamboo and military base perimeter fences to defoliate jungle vegetation, reveal guerilla hiding places and destroy the food supply of enemy troops. South Vietnamese farmers, U.S. and Republic of Vietnam military personnel, and communist insurgents were exposed to these herbicides with immediate and longer term impacts on personal health, civilian household food security and population-wide famine. Agent Blue (cacodylic acid, $\mathrm{C}_{2} \mathrm{H}_{2} \mathrm{AsO}_{2}$,) was the most effective of all the Rainbow herbicides in killing rice and grasses. Manufacturing of cacodylic acid began in the late 1950s in the U.S. at the Ansul Company chemical plant in Marinette, Wisconsin and Menominee, Michigan. During the Vietnam War, ocean going ships were loaded with 208-liter Agent Blue barrels and shipped via the St. Lawrence Seaway to the coast of South Vietnam. Arsenic (As) is a naturally occurring element that is found throughout SE Asia deltas including the Mekong Delta. Today arsenic contaminated rice and groundwater are grow-
\end{abstract}


ing concerns as neither naturally occurring arsenic nor anthropic arsenic have a half-life and cannot be destroyed. Anthropic arsenic has remained in the Mekong Delta environment for the last 60 years and added to persistent As contamination in water supplies, sediments and soils. Water soluble arsenic primarily leaches into the soil root zone and the groundwater or is carried by floodwater into adjacent waterways or volatilized under anaerobic rice paddy conditions as gaseous arsine. The health of 15 million Vietnamese people living in the Mekong Delta is at risk from the combination of manufactured and natural As in drinking water and food supply. The As in the contaminated rice paddy soil, sediment and water is up taken by fish, shrimp or by crop vegetation and trace amounts can end up in the food supply (rice grain) or be bioaccumulated by the fish, shrimp and birds which when eaten were bioaccumulated in the Vietnamese people. It is urgent that elevated As concentrations in water supplies and agricultural products be identified and mitigated through better run-off control and groundwater management; improved rice genetics and alternate crop selections; shifts in crop management associated with tillage, fertilization and phosphorus use; and systematic monitoring of food and drinking water.

\section{Keywords}

Ansul Chemical Company, Arthur W. Galston, Arsenic, As, Food Crops, Groundwater, Marinette, Wisconsin, Menominee, Michigan, Menominee

River, Rice, Rice Paddies, Rainbow Herbicides, Mekong Delta

\section{Introduction}

The U.S. Agency for Toxic Substances and Disease Registry suggests arsenic cannot be destroyed once added to the environment [1]. During the Vietnam War, Agent Blue $\left[\left(\mathrm{CH}_{3}\right)_{2} \mathrm{As} \mathrm{OOH}\right]$ the arsenic based herbicide, was used to desiccate rice plants before maturity. Spraying and dropping of Agent Blue into rice paddies added massive quantities of water-soluble arsenic to the soil root zone and the surface water of the Mekong Delta (Figure 1) rice paddies (Figure 2) and to mangrove forests. The United States and South Vietnamese militaries significantly added to the As load (1,132,400 kg As) in Mekong Delta and the Central Highlands environments as a result of the application of the Agent Blue herbicide. For the last 60 years, highly varying levels of trace amounts of arsenic have been ingested and bioaccumulated by Vietnamese living in the Mekong Delta or Central Highlands from contaminated food and drinking water (Figure $3)$. Two water soluble arsenical species, arsenite ( +3 oxidation state) and arsenate ( +5 oxidation state) are the most abundant in surface water, the soil, and groundwater. The fate of arsenic in the South Vietnam environment included: reacting with and being retained by the solid mineral phase of the soil, volatilized to the atmosphere as gaseous arsine from manufacturing or industrial trans 


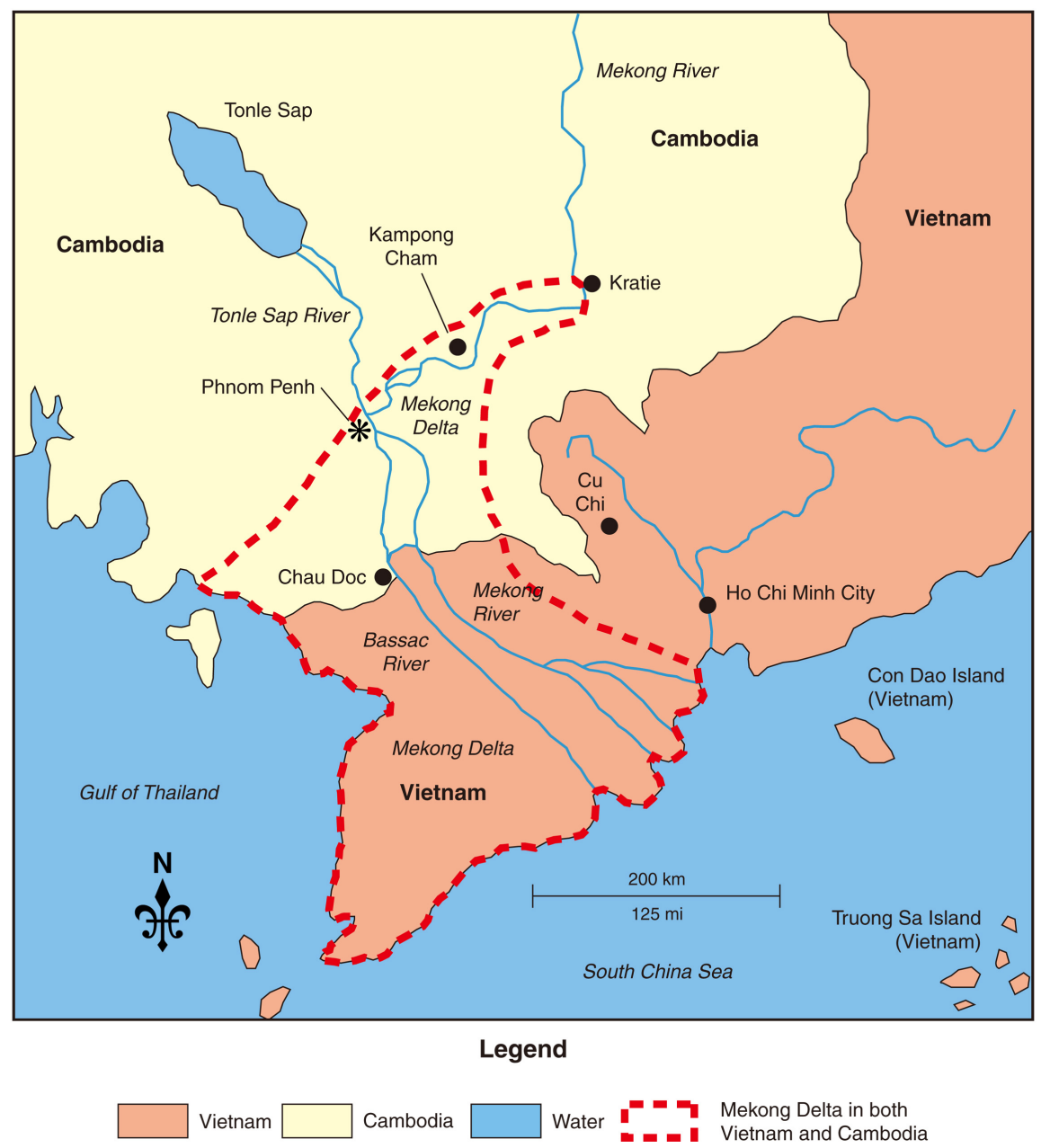

Figure 1. Borders of the Mekong Delta in Vietnam and Cambodia. Map created by Mic Greenberg.

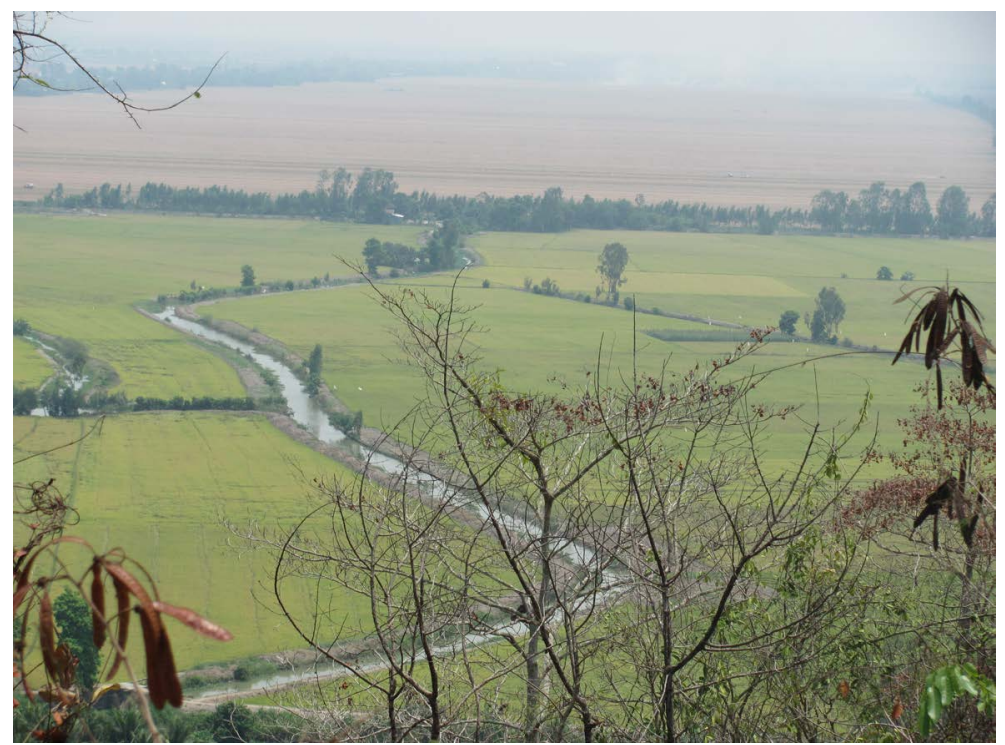

Figure 2. Rice paddies in the Mekong Delta. A view from Sam's mountain located near the Cambodia and Vietnam border. 


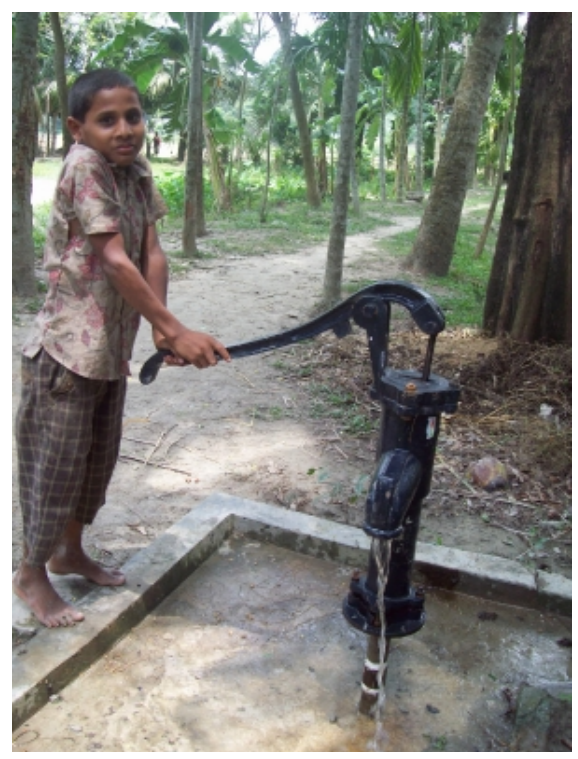

Figure 3. Tubes wells with hand pump used in Mekong Delta.

formations, as arsenic laden smoke and ash particulates from rice plant residue burning, leached from the root zone (soil) and into the groundwater and taken up by rice plant roots from surface water, accumulated in plant residues and returned to the soil, or stored in the grain.

The only major Rainbow herbicide used throughout all 10 years of the Vietnam War was Agent Blue. One-third of Agent Blue was transported from Marinette, Wisconsin and Menominee, Michigan (Figures 4-7) via Menominee River, Green Bay, Lake Michigan [2] and the St. Lawrence Seaway to the 551th Ordinance Storage Depot in Da Nang and the other two-thirds went to the $20^{\text {th }}$ Ordinance Storage Depot in Saigon. Agent Blue was used primarily on grain and cereal crops [3] [4]. Agent Blue was aerially sprayed (Figure 8) [5] on rice seedlings and plants to kill the crop and seed in preparation of areas for crop burning [6]. Burning of dried crop residues likely released volatilized toxic $\mathrm{As}_{4} \mathrm{O}_{6}$ or as fine particulate material $\left(<\mathrm{PM}_{2.5}\right)$ in smoke into the atmosphere [7]. Thus, the U.S. and Republic of Vietnam military personnel and Vietnamese civilians stationed or living in the Mekong Delta and Central Highlands were exposed to airborne As-containing materials.

Water soluble arsenic leached from the rice paddies into the soil root zone after frequent applications of Agent Blue by the U.S. and Republic of Vietnam militaries from 1961 to 1971. After the Vietnam War, vast amount of natural and manufactured arsenic rich groundwater was pumped from more than 100,000 private shallow tube wells onto the land surface to irrigate the rice paddies, fill shrimp ponds and to meet the drinking water needs of the 15 million people living in the Mekong Delta and along the Mekong River (Figure 1). Thus, during the last 60 years, the Vietnamese people living on the Mekong Delta have continued to ingest and bioaccumulated arsenic (from war contamination and natural sources) via their drinking water and food supply. The primary objective of 


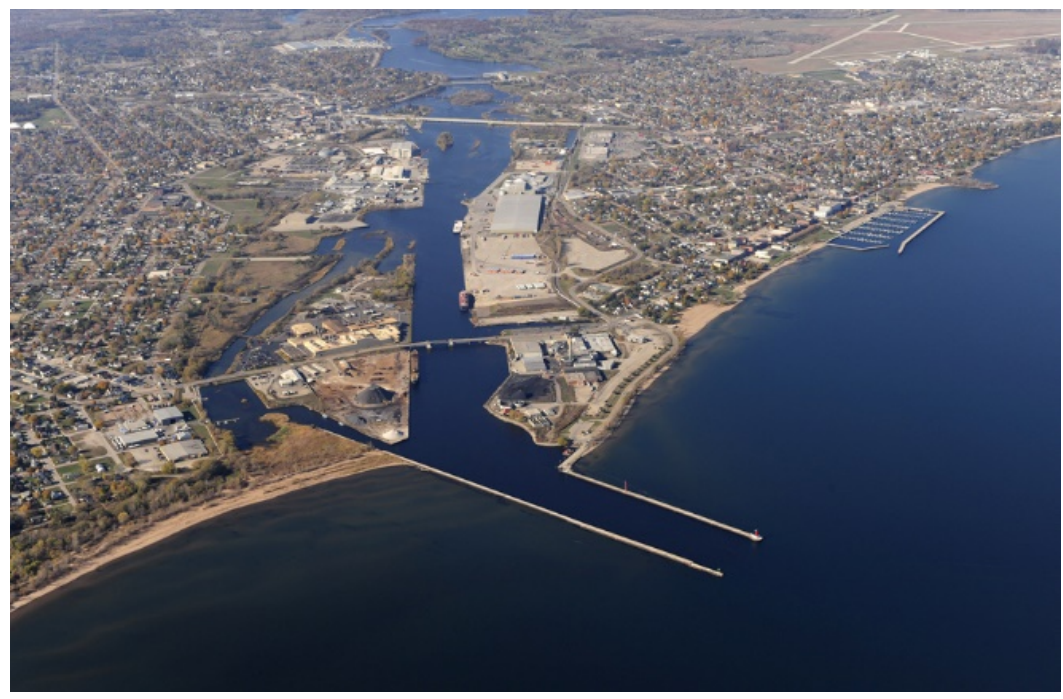

Figure 4. Aerial view of the former Ansul company chemical plant on Menominee River in Marinette, Wisconsin (L) and Menominee, Michigan (R).

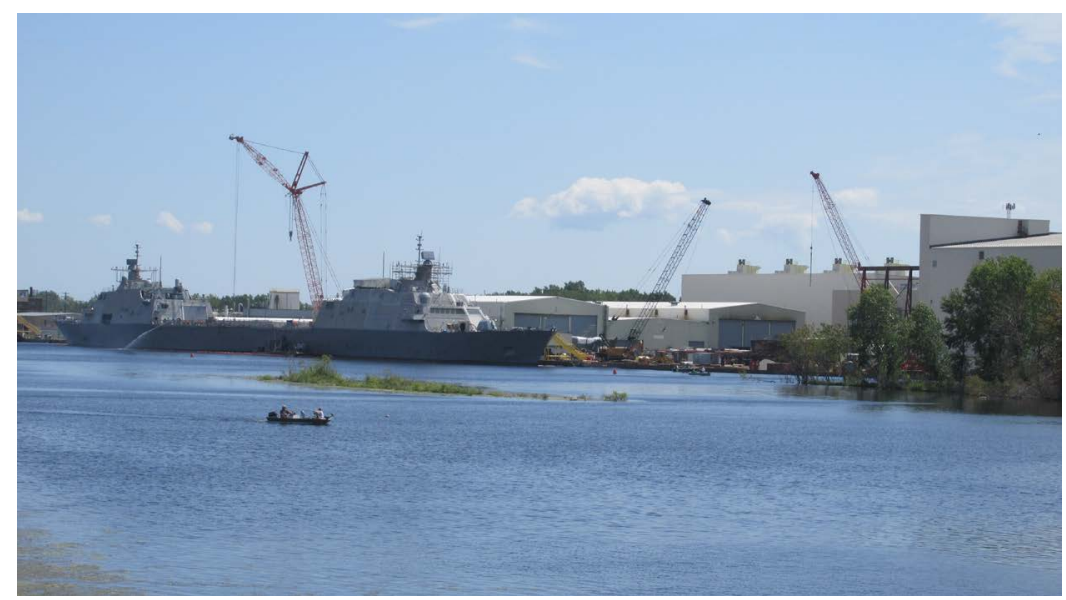

Figure 5. Sea going ship on the Menominee river being loaded with chemicals at the former Ansul company plant in Marinette, Wisconsin.

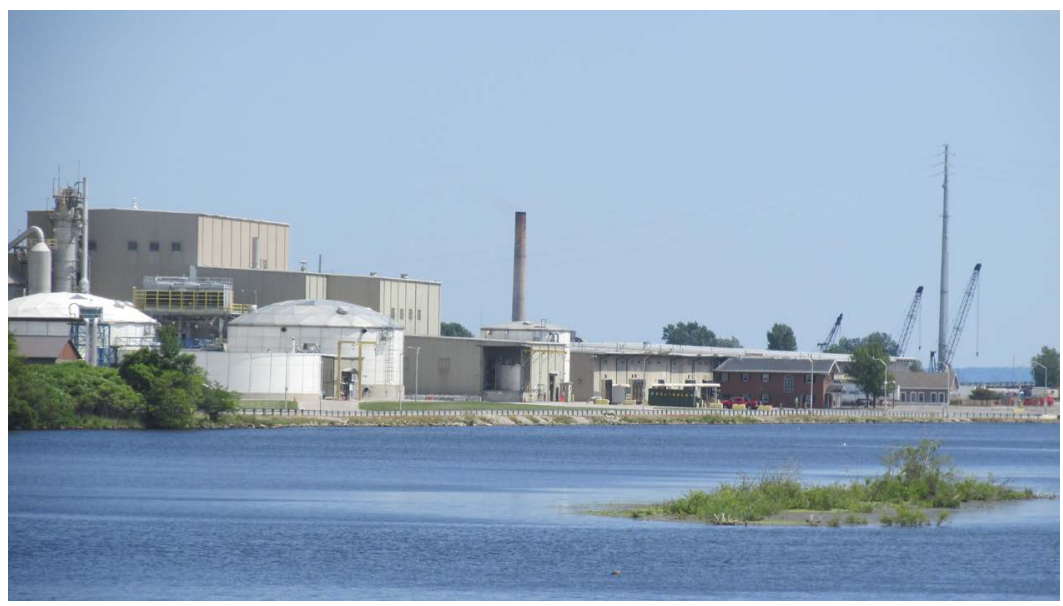

Figure 6. Former Ansul chemical plant site on the Menominee River in Menominee, Michigan. 


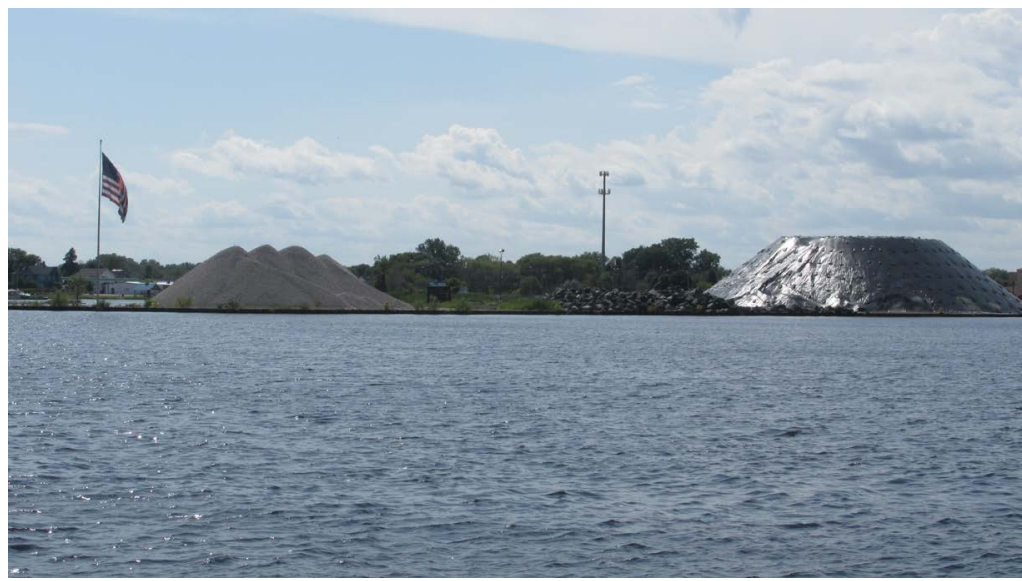

Figure 7. Bulk storage of raw materials where the arsenic ash for making Agent Blue was stored at Ansul Chemical plant on Menominee River in Marinette, Wisconsin during the 1960s and 1970s.

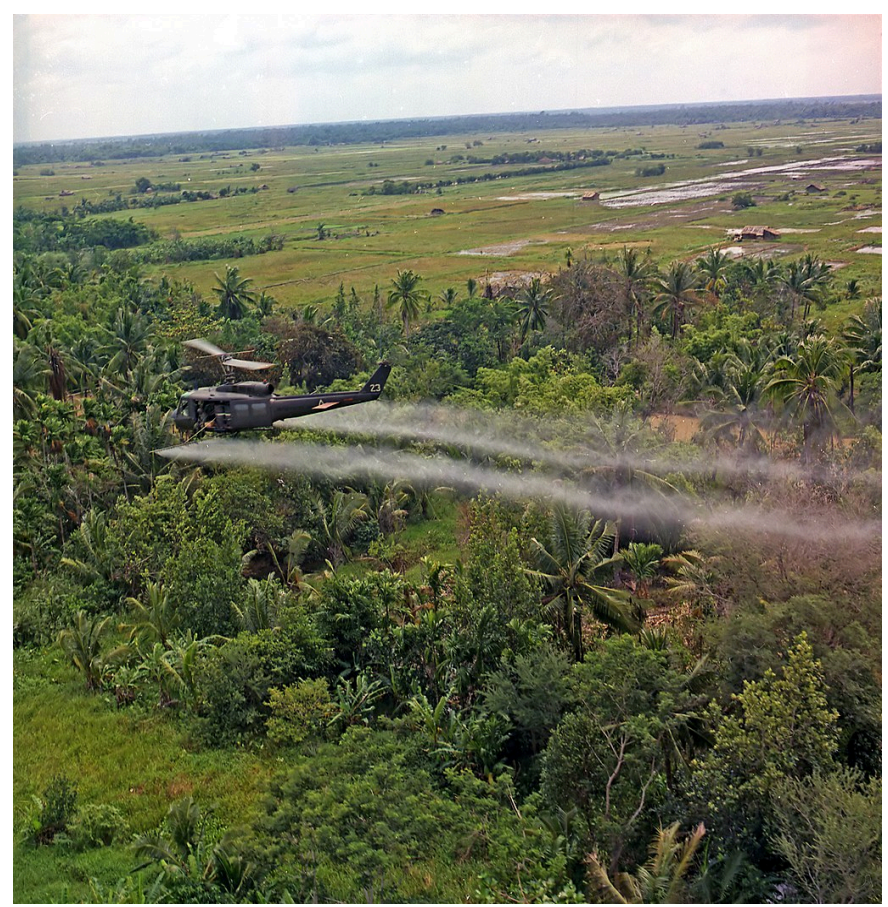

Figure 8. Agent Blue being sprayed by aerial sprayers in the Mekong Delta.

this paper is to determine and describe the environmental impact and fate of Agent Blue, containing 1,132,400 kg of As in the arsenic based herbicide, which was applied from 1961 to 1971 to 400,000 ha of land in South Vietnam by the United States and Republic of Vietnam militaries.

\section{Study Site}

\subsection{Mekong Delta Geography and Geology}

The Mekong Delta, begins near Kratie, Cambodia (Figure 1) and extends east to the South China Sea. The Mekong Delta is the world's largest delta with 65\% in 
Vietnam and 35\% in Cambodia. The $4350 \mathrm{~km}$ Mekong River flows south through multiple channels into the South China Sea. The Bassac River separates from the Mekong River near Phnom Penh; these rivers run parallel and east to the South China Sea. There are nine channels which carry Tibet Highland sediments from the headwaters of the Mekong River and deposit the sediment throughout the Mekong Delta during the monsoon season flood stages, creating natural levees that migrate and can be overtopped and create midstream silt and sand bars [8].

In 2000, almost 900 people were killed as a result of flooding of 2,500,000 ha of agricultural land in the delta. The Mekong Delta is a flat, broad floodplain with alluvial soils (Entisols) [9], but has a "flooded" mountain region west of the Bassac River (Figure 9) [10] and along the Cambodia-Vietnam border and southern coastal dunes along the South China Sea, are also high points above the marshlands and plains. The terrain is the result of folding by collision of Indian

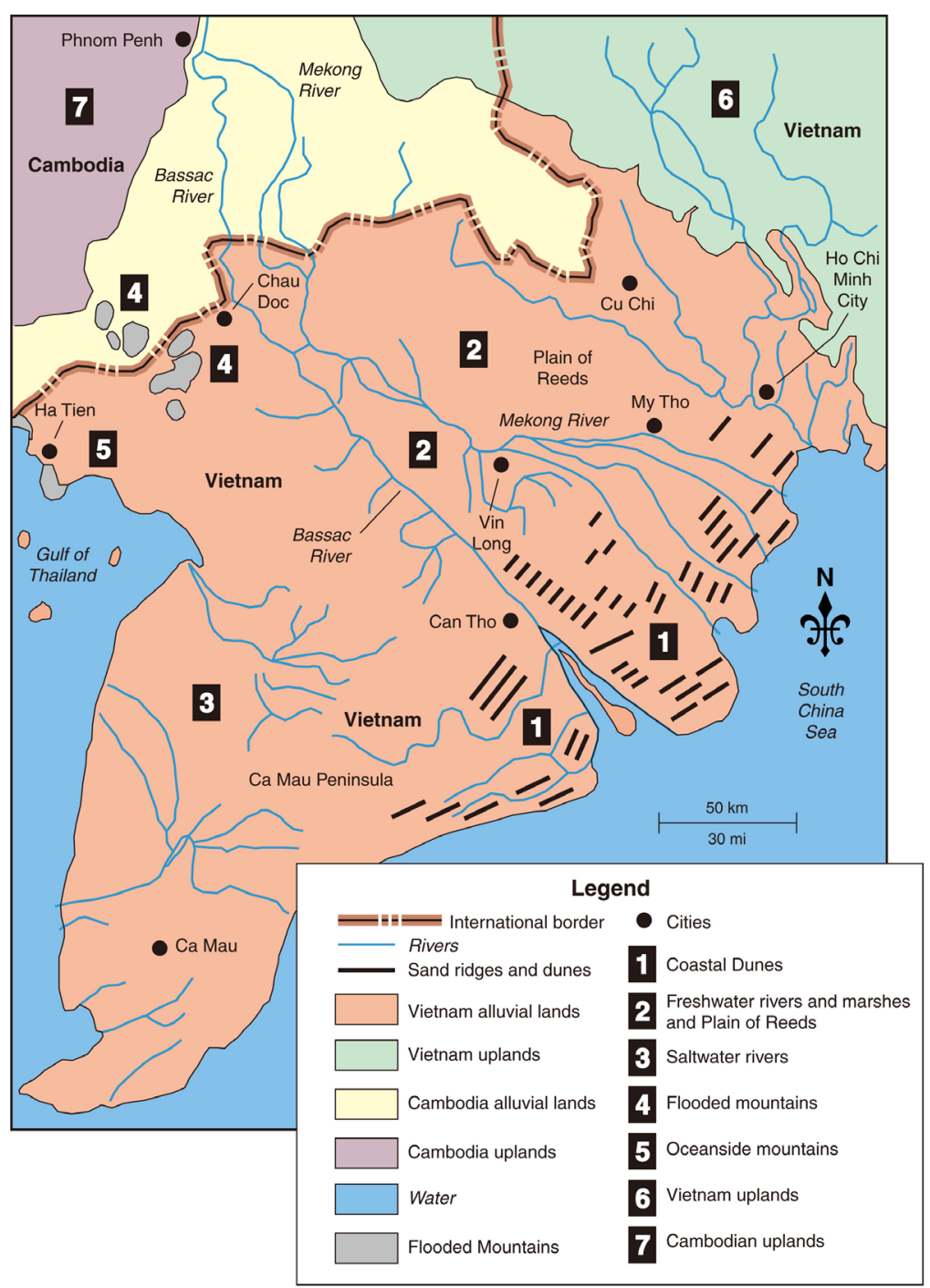

Figure 9. Mekong River landscape map. Re-published with copyright permission from managing editor of JEP [10]. Map created by Mic Greenberg. 
and Eurasian tectonic plates and tectonic uplift [8]. The Mekong River drainage system developed where the underlying geological structure is heterogeneous and active. Historically $76 \%$ of the delta sediments originated in the Tibetan Plateau about 8 million years ago. More recently, the Tibetan Plateau area contribution dropped to $40 \%$ with up to $51 \%$ of the sediment was transported from Thailand and Cambodia highlands [11]. The last glacial period ended abruptly 19,000 years ago when sea levels rose $4.5 \mathrm{~m}$ above present level and the shoreline of the South China Sea reached modern day Phnom Penh, Cambodia (Figure 9) [10].

The Mekong Delta morphology developed during the last 6000 to 10,000 years [12]. The delta covered more than $62,000 \mathrm{~km}^{2}$ of the South China Sea and developed $200 \mathrm{~km}$ to the east over the continental shelf. The Mekong Delta built up through tidal and fluvial tidal process and was sheltered from wave action [13]. About $3500 \mathrm{BC}$, the delta extended beyond the embayment and the delta advancement rate dropped to 17 to $18 \mathrm{~m}$ per year. The delta deposits were exposed to marine currents and wave action that re-distributed the sediment to the southeast creating the Ca Mau Peninsula, a more recent feature of the Mekong Delta. Due to the low flat topography and unconsolidated parent material of the delta the Mekong River has changed course many times. Riverbanks are composed of unconsolidated sediments that are unstable and highly erodible.

\subsection{Soils of Vietnam}

The soils of Vietnam [14] [15] [16] were formed by alternating monsoon [17] and dry seasons, sedimentation during river flooding, and intrusions of the South China Sea. Fertile river delta and alluvial soils (Figure 10) [14] have supported a diverse and concentrated population for centuries. The diverse population made extensive aquaculture and rice cultivation possible. The Mekong Delta soils include Entisols, Inceptisols and Histosols (Figure 11) [5] formed in the annual Mekong River and tributary fluvial deposits from the Tibet Highlands and carried by the river through the land masses of Laos, Myanmar, Thailand, Cambodia and Vietnam and into the South China Sea (Figure 12) [15]. When the South China Sea covered southeast Vietnam millions of years ago "Old Alluvium" soils (Ultisols and Oxisols) formed about $10 \mathrm{~m}$ above the recent floodplain deposits (Entisols) of the Mekong Delta.

The sedimentary sands of Old Alluvium terraces (Figure 9) [10] produced acisols and podzols though clay leaching [14]. Podzols (FAO/Unesco classification) are highly acidic ( 4.5) and have a subsurface horizon which includes iron oxides that are strongly bleached and light grey which grade into a dark brown-reddish illuvial horizon [9]. Acrisols are called "lateritic" podzolic soils because the clay has a low silica: alumina ratio. Acrisols have a base saturation level of under $50 \%$ and a low base exchange capacity of $16-24 \mathrm{meq} / 100 \mathrm{~g}$ clay [14]. Kaolinite is the primary clay with little or no illite or montmorillonite. These soils are termed grey podzolic when the sand fraction of the eluvial horizon 


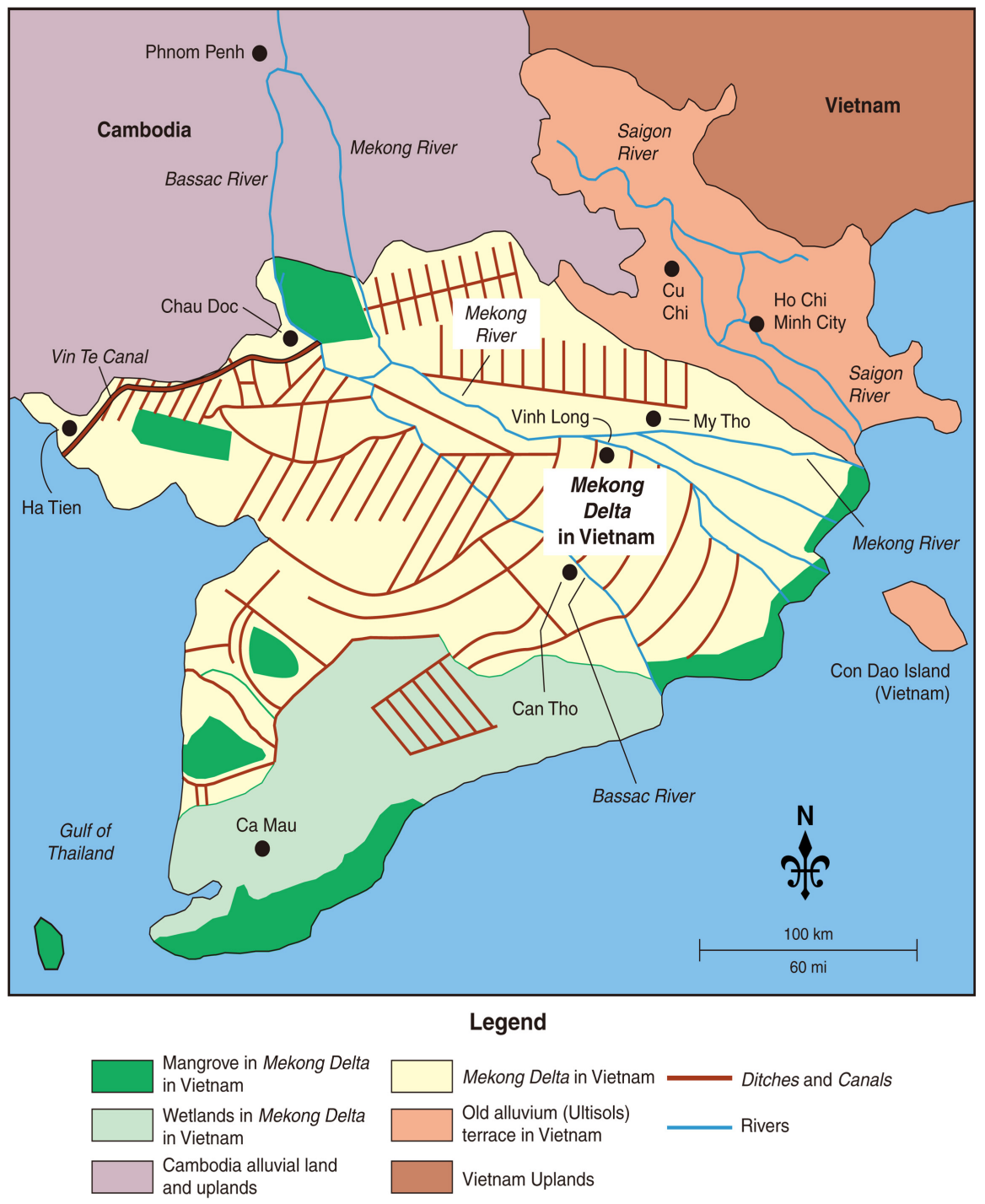

Figure 10. Mekong River and waterways and drainage ditches. Re-published with copyright permission from Managing Editor of OJSS [5]. Map created by Mic Greenberg.

is almost white. According to Dudal and Moormann [14], some grey podzolics are ferric luvisols (rather than ferric acrisols) because their base saturation level exceeds 50\%. Grey podzolic soils are dominant on the Mekong River basin Old Alluvium terraces (Figure 9) [10].

The processes in which the iron content leaches from upper podzolic soil layers and accumulates in lower layers is described by Dudal et al. [16], "the wet season and high temperatures bring about the eluviation of all basic components, potassium, calcium, sodium and magnesium oxides, and high acidity." Concurrently, advanced hydrolysis occurs which leads to degradation of clays and the release of silica, iron oxides and alumina (ferralsols). During the monsoon season the iron content in the reduced form migrates to other layers in the soil. The dry season temporarily fixes the iron oxides and stops the iron $\left(\mathrm{Fe}^{++}\right)$ migration [9]. 


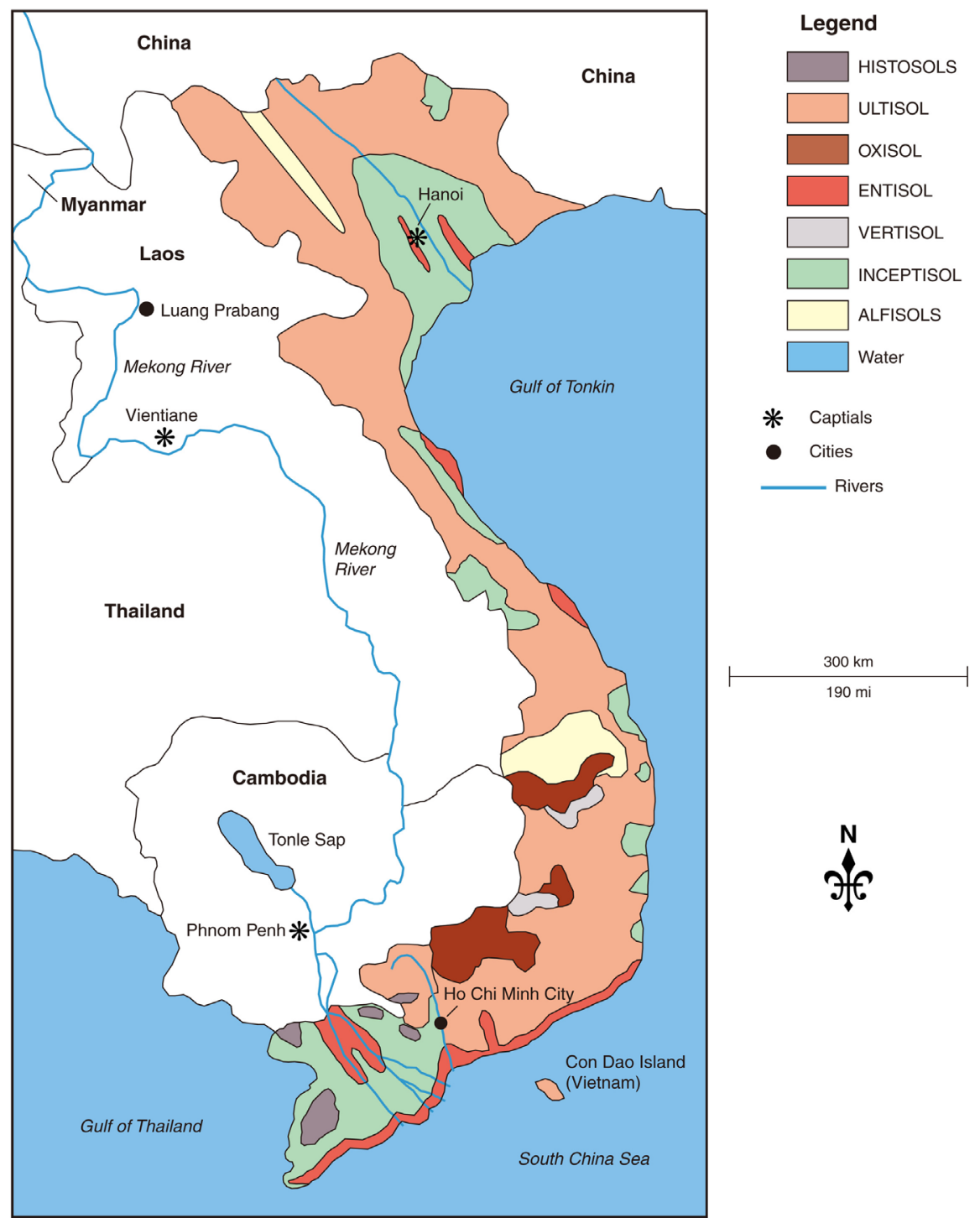

Figure 11. A soil map of Vietnam. adapted from FAO/UNESCO preliminary definitions, legend and correlation table for the soil map of the world. World Soil Resources Report No. 12; Rome: 1964. adapted from Moormann. F. R. the soils of the Republic of Vietnam. Saigon: Ministry of Agriculture, 1961 [15]. Re-published with copyright permission from managing editor of OJSS [18].

\subsection{Delta Wetlands and Mangrove Forests}

Wetlands are distinct ecosystems where soils are seasonally or permanently water-saturated over extended periods from seasonal flooding and/or a high water table [17]. The wetlands of the Mekong Delta range from shallow freshwater depressions and ponds, backwaters of streams and rivers to vast seasonally flooded plains with melaleuca forests, rice paddies, brackish salt marshes, mangrove swamps and tidal mudflats along the coasts, and many small offshore islands [17]. The wetland locations in the landscape include, edges of streams, rivers, and low depressions or coastal seas where precipitation and groundwater accumulated effects of animal and plants communities have adapted to permanent 


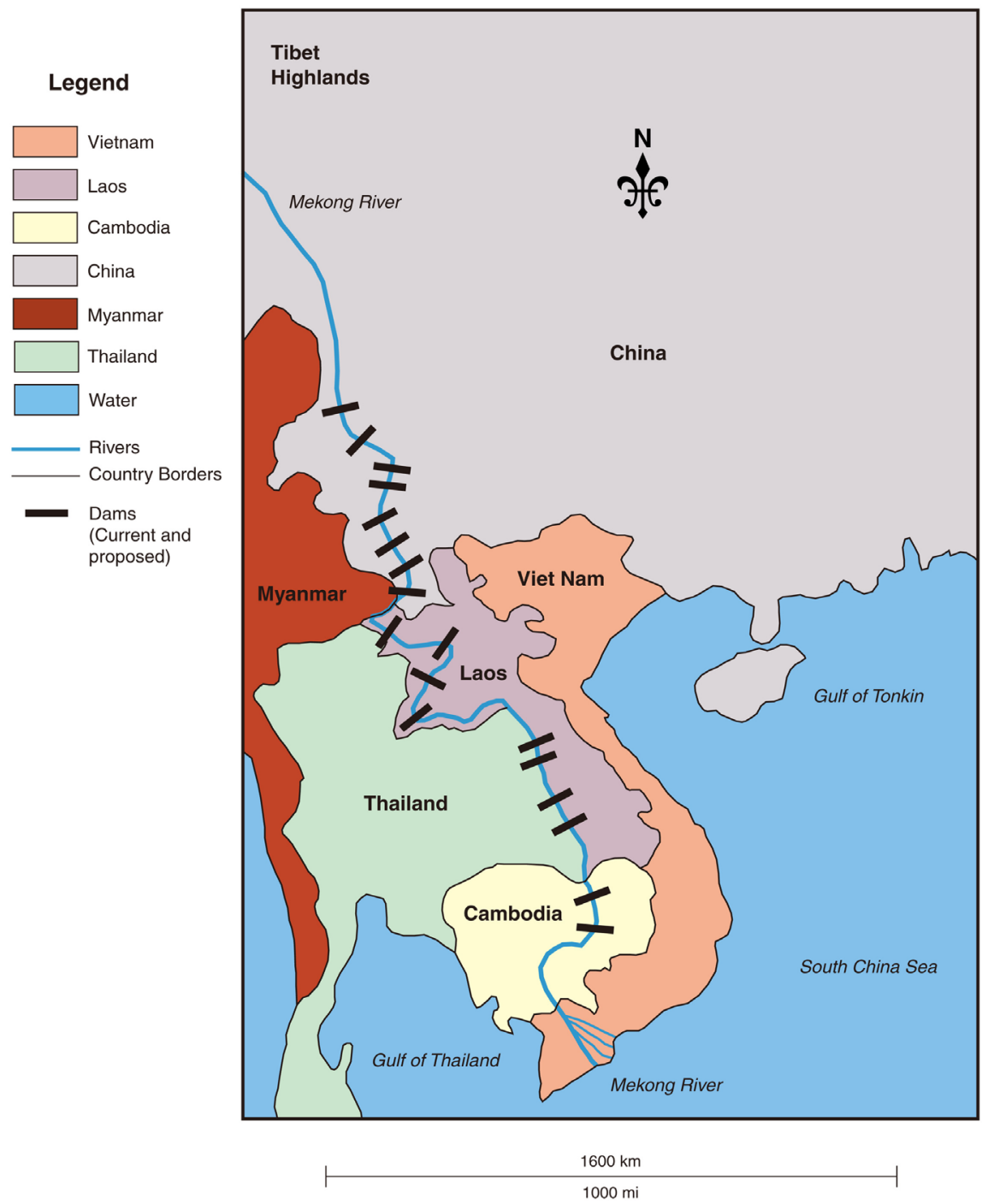

Figure 12. Mekong River from Tibet Highlands to South China Sea. Re-published with copyright permission from Managing Editor of JEP [10]. Map created by Mic Greenberg.

shallow water conditions or fluctuating wet and dry periods.

The hydrology, topography, and climate of the Mekong Delta determine whether the wetland is salt water or fresh water. Flooding and rain during the wet season flush saltwater rivers and canals and temporally replace salty waterways with fresh water. The Plain of Reeds located in Vietnam, freshwater wetlands located in Cambodia, and lands in the central delta both between and on both sides of the Mekong and Bassac rivers have the major wetland areas. Seasonally deposited sediments carried downstream by the Bassac and Mekong rivers are fertile, and when the flooding is moderate the soils [18] in this part of the delta are not acid or saline [19]. The central delta is densely populated with settlements primarily along the river levees where the land is higher and protected from most floods. The seasonally inundated wetlands on the backside of the natural levees and away from the rivers were drained in the late 1970s by canals 
(Figure 10) and the areas became the major rice growing areas.

The delta coastal dunes (Figure 9) [10] were formed by currents, tides and waves of the South China Sea from alluvial sediments and sand of the Mekong River with its nine channels. As the delta sediment deposits extended into the South China Sea, the dunes became inland ridges above the coastal wetlands. These ridges parallel to the $250 \mathrm{~km}$ coastline of the Ca Mau Peninsula, the southern most tip of Vietnam, and receive on average $2 \mathrm{~m}$ of rain during the monsoon season. Home to the $\mathrm{U}$ Minh Ha melaleuca forests and Nam Can mangrove forests, these wetlands create a $5200 \mathrm{~km}^{2}$ coastal ecosystem with diverse and abundant marine and protected the coast from erosion.

Dat Mui Nature Reserve is a delta ecosystem. Much of the original mangrove forests were destroyed during the Vietnam War and later converted into fish ponds and other agricultural uses. Recently the fish ponds have been phased out, and efforts are underway to revegetate coastal mudflats and inland mangrove forests. For example, the BaiBoi Protection Forest on the west coast is being restored to mangrove forest through use regulation and replanting to protect coastal areas from tropical storms [20]. Fisheries, agriculture, expanding settlements, roads, tourism and aquaculture throughout the peninsula have replaced many of the native coastal wetlands. This has increased the region's vulnerability to storm surges, typhoons, sea level rise from a changing climate, coastal erosion, environmental pollution including Rainbow herbicides applied during the Vietnam War and mangrove logging for conversion to rice paddies and shrimp farming [18].

\subsection{Rice as a Dietary Staple and Food Security}

The Mekong Delta and coastal regions of South Vietnam are wet landscapes with highly productive alluvial soils and extensive dike systems uniquely managed for rice production [18]. Flooded or wet rice production dominates the region with rice grown in the lowlands behind natural and human constructed levees which flood during the wet season [21] [22]. Rice is sown during the rainy season, grown in shallow waters, matures and is harvested as the water levels drop with the onset of the dry season.

Rice has been a staple food in South East Asia for centuries. It is a source of food security and livelihoods with most Mekong Delta farmers cultivating rice for family meals, straw and hulls for livestock, and family income. Rice is eaten at all three meals and provides about $75 \%$ of Vietnamese daily calories. South Vietnam rice production during Vietnam War dropped almost 50\% from $8 \mathrm{M}$ ton/ha to $4.5 \mathrm{M}$ ton/ha in 1966; and then in 1969 began an upward rise reaching $7.5 \mathrm{M}$ ton by 1974 [23]. Per capita rice consumption in the Vietnam War and post-war years ranged from $150 \mathrm{~kg}$ in 1962 to a low of $107 \mathrm{~kg}$ in 1978 [24]. This compares to $217 \mathrm{~kg}$ per capita rice consumption in 2015. A large portion of the population of Vietnam, one of the poorest countries in Asia, prior to the 1980s market reforms and introduction of Green Revolution technologies suffered high levels of food insecurity [25]. 
Food security involves adequate availability of food grains, stability of food supplies, and household access to food [26]. Sources of food insecurity range from inadequate financial resources for food production inputs and agricultural management practices to the extreme and uncertain weather and climate patterns. In the Mekong Delta, the frequency of inter and intra-seasonal extreme flooding and drought cycles often result in rice production shortfalls. When coupled with unstable political and social conditions, conflicts and wars, and degraded and contaminated soil and water resources, food insecurity has led to poor nutrition, famine, and premature deaths.

The casualties of war are primarily measured in soldiers killed and wounded. Often overlooked are the short and longer term impacts of war on civilian populations. One of those impacts is food insecurity and malnutrition which lead to early deaths and persistent poor health that saps the energy for everyday living and workforce well-being necessary for economic recovery. Vietnam is no stranger to famine. During World War II (1944-1945) famine killed a million Vietnamese due to population pressure, falling rice-paddy output, poor weather and cultivation methods which reduced the 1944 rice crop drastically [27]. Rice re-distribution from other areas was prevented when the north-south railway and bridges (Figure 13) in Vietnam were bombed and submarines along the coast controlled shipping and access to ports preventing food shipments.

The use of herbicides to defoliate the South Vietnamese landscape [28] not only killed trees, the undergrowth and tall grasses but also the gardens and rice crops that were the source of population food security. One of these herbicides, Agent Blue containing a synthetic arsenic, was a powerful contact desiccant that killed grasses and rice within hours [28]. This not only enabled landscape level follow-up burning and clearing of all vegetation for military purposes but also resulted in crop loss and food insecurity for the resident civilian Vietnamese population.

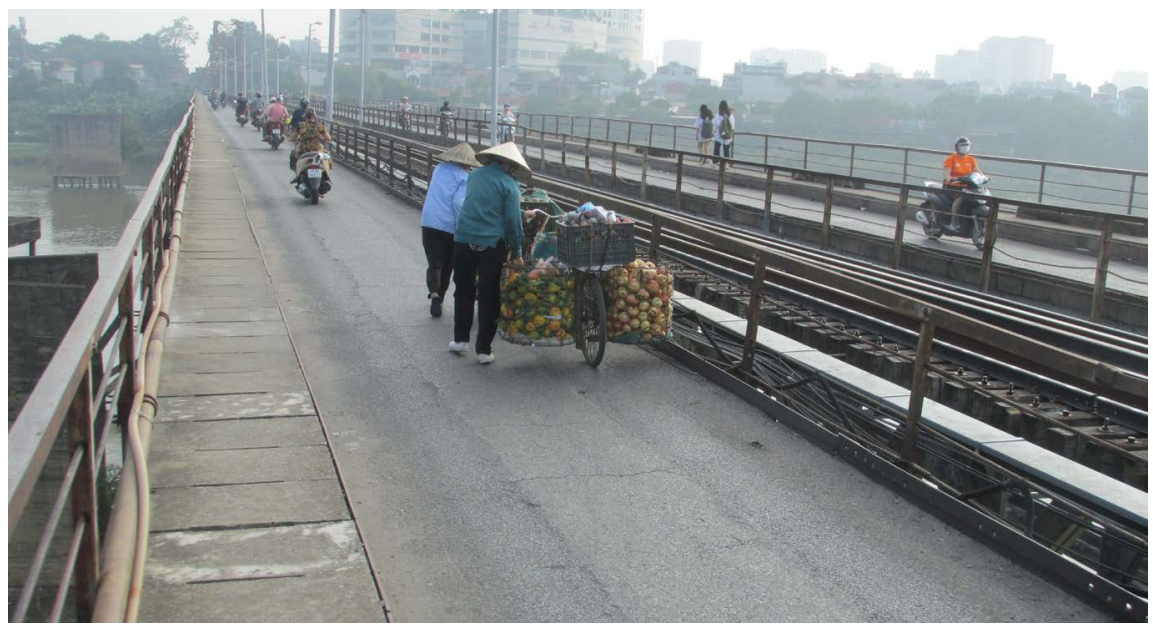

Figure 13. A Hanoi railroad bridge across the Red River currently used by a train, motorcycles, bicycles and pedestrian traffic. The bridge was repeatedly bombed by the U.S. Air Force during the Vietnam War. 
Arsenic availability to rice plants is primarily influenced by soil physical and chemical properties. Soils that have high As retention capacities (sands and loams) can lead to increased As concentration in the soil surface and decreased root and shoot lengths [29]. Arsenic interferes with plant metabolic processes, inhibiting plant growth and at high concentrations kills the plants [29] [30]. Arsenic toxicity affects the root anatomy, root oxidizability, electrolyte leakage, water content, lipid peroxidation and damages protein, amino acids and nuclei acids, and antioxidant activities in rice [30]. Rice plants are most sensitive to As toxicity during their early growth period. Their defense mechanisms are underdeveloped and seedling growth, roots and shoots are highly vulnerable [29]. Rice grown in flooded conditions is especially at risk from not only direct herbicide applications via aerial spray to their shoots but also from arsenic that accumulates in rice paddy sediments and paddy waters with toxic effects to current and future crops [31] [32]. Arsenic in rice paddy waters increases the concentrations of As in the rice grain, hulls and straw [31] and can bioaccumulate in animals and humans as it is transported by blood to different organs in the body [29].

Arsenic is a naturally occurring element in sediments of major river basins throughout SE Asia and the Mekong Delta region of Vietnam [33]. There is no known chemical difference between natural and synthetic As; both persist in the environment and do not degrade with exposure to sunlight or dissipate over time. Thus, unlike other Rainbow herbicides used in Vietnam [26], the active ingredient As in Agent Blue can persist in agricultural fields for centuries and can easily be transported throughout the landscape via soil erosion, sediment deposition and water flows. The repeated applications of the synthetic arsenic-based herbicide during the Vietnam War period not only killed the rice crop leading to immediate reduction in rice food supplies and food insecurity, but the concentration of As in the environment increased throughout the region. More recent research finds that repeated exposure to As in rice crops leads to soil sterility and unproductive crops with soil contaminated residues posing problems to sensitive crops used in rotations with rice [29]. Solid-phase arsenic is found buried in river and paddy sediments and released to groundwater during microbial mediated reductive dissolutions of ferric oxides [33] which are abundant in South Vietnam [9]. Repeated human consumption of groundwater containing natural and synthetic arsenic poses a significant health threat [30] [33].

\subsection{Arsenic}

Arsenic, a natural element with an atomic number of 33, is present in the biosphere, hydrosphere, pedosphere and atmosphere. Arsenic is the $12^{\text {th }}$ most common element in the earth's crust, $12^{\text {th }}$ most abundant element in the human body, and $14^{\text {th }}$ most abundant in seawater [34]. There are four oxidation states of arsenic: $-3,0,+3$ and +5 . Gaseous arsine, in the form of $\mathrm{AsH}_{3}$, is characteristic of the -3 oxidation state and elemental arsenic is characteristic of the 0 oxidation state. The most common As species are arsenite [As (III)] which is characteristic 
of the +3 oxidation state; and arsenate $[$ As $(\mathrm{V})]$ which is characteristic of the +5 oxidation state [33]. The most readily available oxidation states for bioaccumulation are the +3 and +5 oxidation states but can be ingested in the As $(-3)$ form by inhalation.

Arsenic, as the crystalline oxides $\mathrm{As}_{2} \mathrm{O}_{3}$ and $\mathrm{As}_{2} \mathrm{O}_{5}$, is hygroscopic and readily soluble in water to form acidic solutions. Arsenic salts are called arsenates which are weak acids and the most abundant arsenic contaminants in groundwater and contaminate the drinking water of the millions of Vietnamese living on the Mekong Delta [35]. These arsenic oxides can also be decomposed when As-containing biomass is burned forming As-containing aerosols at burning temperatures below $400^{\circ} \mathrm{C}$. This decomposition and formation of aerosol compounds are aided by the presence of carbon (charcoal) even at temperatures below $200^{\circ} \mathrm{C}$. Particulate As-containing aerosols (airborne ash) can also contain inhalable As during smoke exposure [7].

Arsenic is a natural constituent of water, soil, animals and plants. The average arsenic content in soil is $5 \mathrm{ppm}$ but can vary from 1 to $40 \mathrm{ppm}$ while fresh and sea water contain between 0.003 to $0.05 \mathrm{ppm}$. Crystalline rock has an average 2.0 ppm, table salt $2.71 \mathrm{ppm}$, and most edible parts of plants are between 0.1 and 1.0 ppm but sometimes as high as $3 \mathrm{ppm}$ and higher on a dry weight basis [36]. Arsenic is water soluble but rarely found in its elemental form, rather, it forms compounds called arsenicals. Arsenicals are detected in more than 200 different minerals [37]. Arsenicals are often associated with complex sulfurous minerals made up of sulfur, gold, iron, copper, silver, nickel, antimony and cobalt due to the anionic ion structure being similar to sulfate $\left(\mathrm{SO}_{4}^{2-}\right)$.

Arsenic is a chemical element which occurs in many minerals. Arsenic and its compounds including the trioxide are used in insecticides and pesticides. Arsenical herbicide use is declining due to the toxicity of arsenic and its compounds. Arsenic the $53^{\text {rd }}$ most common element in nature comprises about $0.00015 \%$ of the Earth's crust. Typical background concentrations of arsenic are about 100 $\mathrm{mg} / \mathrm{kg}$ in the soils, usually less than $10 \mathrm{ug} / \mathrm{L}$ in freshwater and $3 \mathrm{ng} / \mathrm{m}^{3}$ in the atmosphere.

\subsection{Natural and Geologic Sources of Arsenic}

There are two geological layers in Mekong Delta geological strata that produce the abundance of arsenic and they are the natural sources of arsenicals in both groundwater and soil [37]. The upper layer was deposited during the Holocene period and above alluvial sediment from the late Pleistocene period. These two geologic layers with arsenic were derived from the Tibet Highlands (Himalayas) sediment transported to the Mekong Delta by rainfall and runoff (Figure 12). The Holocene sediment layer usually occurs at a 20 and $120 \mathrm{~m}$ depth but can be as deep as $250 \mathrm{~m}$. It is an arsenic rich top layer that is more susceptible to weathering and groundwater flow. The underlying Pleistocene sediment layer has low $\mathrm{pH}$, is rich in organic matter, contains pyrite and sulfate and creating 
reducing condition that contributes to the release of arsenic from the overlying Holocene sediment [34].

\subsection{Origins of Agent Blue, an Arsenic Based Chemical Weapon}

Numerous arsenic based chemical agents were invented and used in past warfare. The Chinese invented the poisonous smoke ball, around $1000 \mathrm{BC}$, which contained arsenic oxide $\left(\mathrm{As}_{2} \mathrm{O}_{3}\right)$ [38]. It was the precursor to modern-day grenades. The first known arsenic based chemical weapon use was in 431-404 BC by the Spartans. Arsenic was used as a noxious smoke against Athenian-allied cities during the Peloponnesian War. During the WWI the first modern arsenic based chemical weapon appeared and contained arsenic and organic compounds.

Lewisite, one of the deadliest poisonous gases, was developed after WWI [39]. Large-scale production of Lewisite began during WWII in the United States, Germany, Great Britain, Japan and the former Soviet Union. Later, North Korea, Iraq and Libya manufactured and used Lewisite. The era of Rainbow herbicides (specific herbicides were coded by color) started during the Vietnam War. From 1961 to 1971 Agent Blue was used by the South Vietnamese and American military to kill rice, bamboo and banana vegetation in South Vietnam [35].

Arsenic undergoes a cycle in an agricultural ecosystem involving arsenic herbicides and fertilizers, uptakes by the plants and consumption by the animals, release by plants and animals, binding with soil and transferred between soil and water. Arsenate is the most stable and generally tends to accumulate in oxidizing (oxygen rich) environments. The arsenite occurs near the root under reducing anaerobic soil conditions. Most bacteria are unable to use arsenic compounds as respiratory metabolites.

Arsenic poisoning of organisms occurs when exposed to quantities much larger than needed. Arsenic contamination of groundwater is a problem that affects millions of people living on Southeast Asia deltas including the Mekong Delta. The United States Environmental Protection Agency (EPA) considers all forms of arsenic a significant risk to human health [1].

Arsenic is classified as a Group-A carcinogen. The U.S. Agency for Toxic Substances and Disease Registry (ATSDR) ranks arsenic No. 1 on its Hazardous Substances at Superfund sites [40]. Synthetic arsenates include calcium arsenate, cupric hydrogen arsenate, and lead hydrogen arsenate. These 3 synthetic compounds, used prior to and during the Vietnam War, have also been used in agricultural herbicides, insecticides, and poisons. The list is based on overall toxicity and potential for human exposure and frequency of occurrence at $\mathrm{Na}$ tional Priority List Superfund sites. This list ranks chemicals using an algorithm or formula that translates potential public health hazards on a points-scaled system

[40]. No human body system is immune to harm caused by arsenic.

\subsection{Cacodylic Acid}

Cacodylic acid, $\mathrm{C}_{2} \mathrm{H}_{2} \mathrm{AsO}_{2}$, is created by reducing disodium methylarsenate with 
sulfur dioxide and converting the sodium salt to the resultant arsenomethane. The solubility in water of both sodium salt and acid are extremely high (over 83 $\mathrm{kg} / \mathrm{liter}$ ). The active component of Agent Blue, cacodylic acid, is water soluble and non-volatile but, being an organic (C or carbon-containing) compound, it decomposes rapidly to non-soluble, relatively non-toxic, inorganic arsenical compounds in water and soil. The chemical is stable in sunlight. Chemical and physical properties of cacodylic acid effect the fate in the soil and plants.

Cacodylic acid is a contact herbicide and only kills tissues with chemical symptoms appearing within two days since it lacks mobility. It is not effective if rain falls within a few hours of the treatment. Sub-lethal doses induce malformed inflorescence, defoliation and fewer seeds. Cacodylic acid appears to undergo limited breakdown in plant tissues.

Since it contains $\mathrm{C}$ in its chemical structure, microflora in the soil degrades cacodylic acid. Under aerobic conditions the breakdown is slow but is much more rapid under flooded and anaerobic conditions. The ultimate environmental fate is a change from organic to inorganic arsenate which occurs primarily in soil. Soils naturally contain $5 \mathrm{ppm}$ of arsenic in the inorganic form [41]. In Southeast, Asia rubber plantations sodium arsenite was been applied for over 20 years at high rates without causing any crop damage due to As fixation by soil minerals and compounds under aerobic conditions.

Plants absorb cacodylic acid from the soil more readily than inorganic arsenic. Evidence suggests that crops do not suffer injury on the land which was previously treated. However, excessive rates on soil unusually rich in phosphates can cause injury to sensitive plants such as peanuts and rice. In humans toxicity rating of cacodylic acid is 3, or medium toxicity. Toxicological data for Ansar 160 (16.8\% arsenic) and Ansar 560 (15\% arsenic) are similar to Agent Blue.

\subsection{Sodium Cacodylate}

Sodium cacodylate trihydrate $\left(\mathrm{C}_{2} \mathrm{H}_{6} \mathrm{AsNaO}_{2}\right)$ is metabolized to produce inorganic, trivalent arsenic, a buffering vehicle used with cacodylic acid and is also an organic arsenic compound. Sodium cacodylate, a salt, neutralizes the acid part of cacodylate acid. Sodium cacodylate is used currently as a source of arsenic in toxicological research. Sodium cacodylate is often used as a buffering agent in preparation and fixation of biological samples for electron microscopy. During the Vietnam War Agent Blue was sold as Phytar G. Sodium cacodylate functions as a buffering agent in Agent Blue to prevent a rapid change in $\mathrm{pH}$ when acids or bases are added to the solution. When heated for decomposition or in contact with acids or acid fumes the poisoning potential is high because it emits highly toxic fumes containing arsenic which then can be inhaled.

The main active component in Agent Blue is cacodylic acid. The non-selective herbicide kills a wide variety of herbaceous plants. It is a non-volatile, highly soluble organic arsenic compound which is broken down in soil. Acute and chronic toxicity in a variety of animals indicate a low to medium toxicity rat- 
ing since inorganic arsenate is bound as insoluble compounds that exist naturally in soils.

China was the top producer (70\%) of white arsenic followed by Morocco, Russia and Belgium. Most arsenic refinement operations in both Europe and U.S. have been closed as a result of environmental concerns. Arsenic is also found in smelter dust from gold, copper and lead refinement [41].

Environmental Protection Agency (EPA), World Health Organization (WHO), and European Union (EU) all recognize arsenic contamination as a significant threat to human health [41]. The WHO guideline for untreated water is 100 $\mathrm{ug} / \mathrm{L}$ prior to being processed for consumption and is $10 \mathrm{ug} / \mathrm{L}$ for processed drinking water. Ingestion includes eating meat and products from animals that were fed with arsenic feed additives, food crops that grew from arsenic-laced irrigation water [42] as well as arsenic rich drinking water from groundwater wells.

Food and agricultural researchers initially thought that organic arsenic [42] would never become inorganic arsenic. However, now there is considerable doubt about this concept [43]. Chickens in the U.S. were given compounds with organic arsenic in them to make the meat more plump, redder and prevent certain chicken diseases. The chicken and chemical industries had insisted the arsenic in the compounds was organic. However, the livers of chickens fed with organic arsenic compounds were found to contain more arsenic than the control group. Researchers concluded that organic arsenic had been converted (transformed) into the lethal inorganic arsenic. After a release of a 2011 peer-evaluated FDA study 89 forms of 102 arsenic compounds which could potentially be converted from organic to inorganic arsenic were removed from the market. Arsenic is a heavy metal and thought to be a carcinogen and dangerous.

WHO suggests $10 \mathrm{ug} / \mathrm{L}$ is the safe drinking water standard. Many countries ignore this standard since it takes decades for people to begin to show symptoms of As poisoning. In Vietnam, the legal arsenic concentration standards are 50 ug/L or 5 times greater than the WHO standard. Groundwater in Red River Valley and Delta (Figure 14) and Mekong Delta in Vietnam is naturally high in arsenic from arsenic-rich clayey alluvial materials origination in Tibet Highlands. The alluvial soil parent materials consolidate when groundwater is extracted and water soluble arsenic (forms arsenate and arsenite) is released into the groundwater.

\subsection{What Is the Difference between Organic and Inorganic Arsenic?}

Arsenic atoms can combine with other elements atoms to form two types of compounds, "inorganic" and "organic" [43]. When arsenic atoms are attached to a carbon atom it forms a highly complex, non-toxic organic arsenic molecule. The inorganic arsenic compounds do not contain carbon, are simple molecules, but are highly toxic [43]. The reason organic arsenicals are non-toxic is because arsenic atoms are tightly bound with bio-molecules including proteins. 


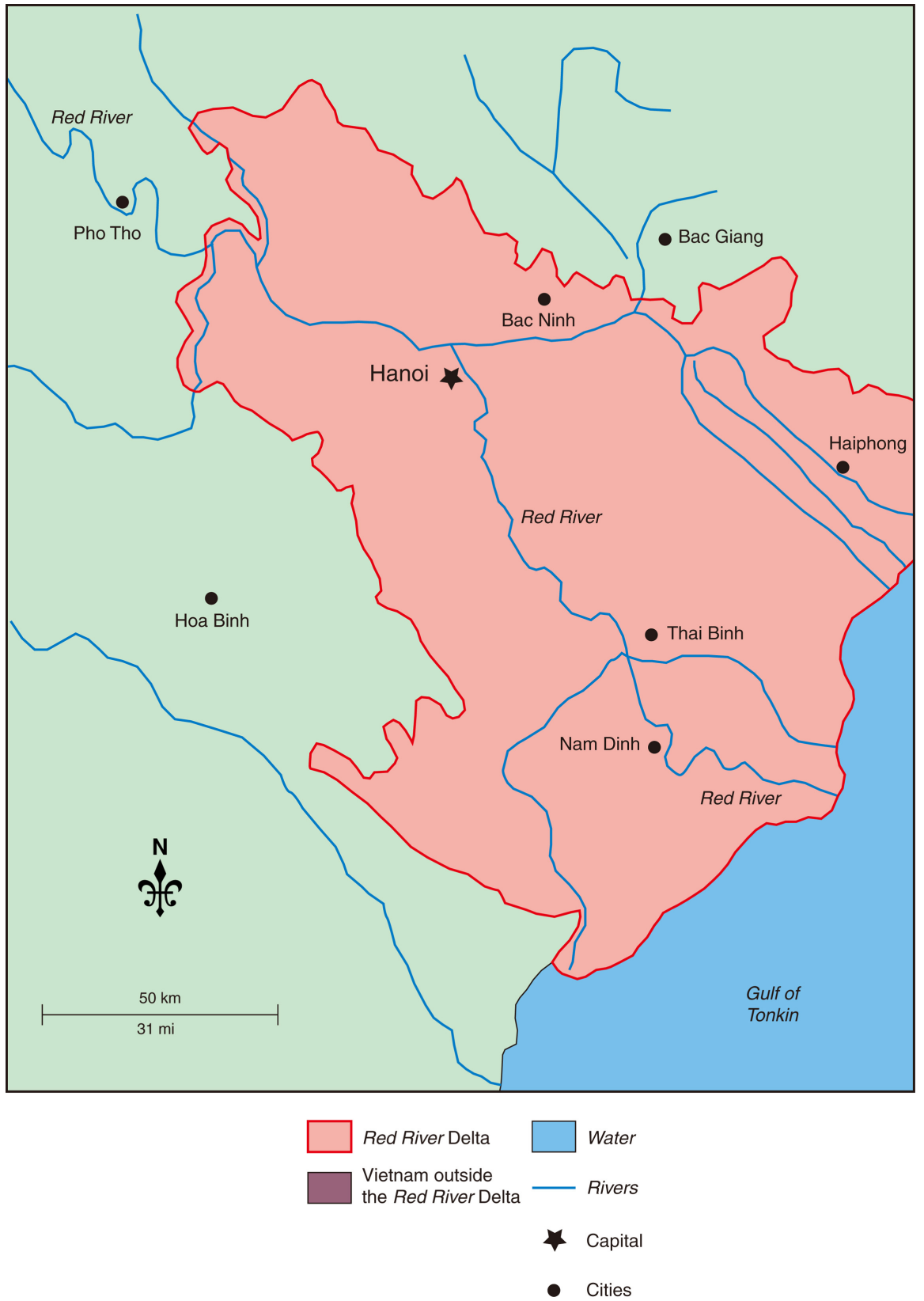

Figure 14. Red River valley and delta. Map created by Mic Greenberg.

Groundwater can contain inorganic arsenic in the form of arsenite or arsenate in which arsenic is bound to oxygen atoms.

\subsection{Effect on Animals and Humans}

The Vietnam War's "KhaiQuang" a South Vietnamese program (1961 to 1965) and the U.S. Military's 1965 to 1971 "Operation Ranch Hand" [3] spraying of Agent Blue (Figure 8) contributed to the arsenic contamination crisis in the rice paddies of South Vietnam and may have contributed to elevated levels in the Mekong Delta groundwater. Agent Blue is also known to deteriorate the barrels which held the herbicide and break down within three months releasing bio- 
available forms. Leaked water soluble arsenic compounds then infiltrated the groundwater and entered the food chain [44].

The main Agent Blue herbicide tests were conducted in 1964 in Thailand to determine the minimum rates. Agent Blue was also tested in 1963-1967 at sites in Puerto Rico, on Kauai Island, Hawaii in 1967-1968, in Korea in 1968 and in Mississippi in 1969 [45] [46].

\subsection{Toxicity of Arsenic and Effects on Human Health}

The organic and inorganic forms of arsenic can be found in soil, water and food around the world. Inorganic arsenic is not usually in water and food that we ingest but is found in the soil. Organic arsenic is not thought to be harmful except in high doses. However, inorganic arsenic is highly poisonous and is a known carcinogen.

Approximately $29 \%$ of As exposure by humans comes from water and $70 \%$ from ingested food [47]. Once ingested arsenic can be bioaccumulated in the body. Arsenic in groundwater [48] is a significant source of arsenic in humans and the two arsenicals most abundant in water are arsenite $(+3)$ and arsenate $(+5)$. In order of toxicity from the most toxic to least toxic are arsines, arsenites, arsenoxides, pentavalent arsenicals, arsenium compounds, arsenates, and metallic arsenic [34]. It accumulates in the body when ingested in small doses due to low excretion rates. It often takes decades before physical symptoms of arsenic poisoning show.

While arsenic is highly toxic in excess amounts, it is a common element in the human body because it commonly exists in the environments that humans inhabit. The lethal dose for rates is $48 \mathrm{ug} / \mathrm{L}$ which translates to $125 \mathrm{mg}$ for a middle-aged male [48]. The maximum safe limit for arsenic ingestion of an average middle-aged male is $220 \mathrm{ug}$ per day. This lethal dosage puts arsenic in a high toxic category within food toxicology. Environmental toxicity of As is affected by organic matter content, redox potential $(\mathrm{Eh})$, hydrogen potential $(\mathrm{pH})$, adsorption to solid mineral particles, and the presence of iron and magnesium and other substances in soil. Arsenic cannot be produced by the human body. Immune system effects of arsenic exposure include cytokine production in lymphocytes and immune-related gene expression. Arsenic is associated with increases in infant morbidity from infectious disease and related to reduced T-cell numbers alongside altered cytokine profiles in core blood, and increased inflammation [40].

\subsection{Development of Arsenic Based Warfare Agents}

The precursor reagent, cacodylic acid, was invented at Fort Detrick in 1957. In soil, cacodylic acid is degraded by the microflora. Breakdown is slow under aerobic conditions, but much more rapid in rice paddies with flooded anaerobic soils. The ultimate environmental fate is a change from organic arsenate to inorganic arsenate which is bound as insoluble compounds in soil. Soils naturally 
contain arsenic in this form, the average content being 5 ppm [40]. Excessive sodium arseniterates of application on soils unusually rich in phosphates can cause injury to sensitive plants such as peanuts and rice because of its similarity in ionic structure to $\mathrm{PO}_{4}^{3-}$ and $\mathrm{SO}_{4}^{2-}$ ions occurring in soils. High phosphate in the soil competes with the inorganic As species for adsorption sites on soil particles and force the As species to remain free in the soil solution. Agent Blue made up $9 \%$ of all Rainbow herbicides sprayed was used for food crop destruction ( $97 \%$ of applied material), and vegetation control along base perimeter fences ( $3 \%$ of material used).

\subsection{Ansul Company Chemical Manufacturing Plant}

The Ansul Company (Figure 15 and Figure 16) produced Agent Blue, labeled as Phytar $560 \mathrm{G}$, at chemical plant in Marinette, Wisconsin [2]. The product consists of $59.5 \%$ water, $26.4 \%$ sodium cacodylate (sodium dimethylarsenic acid),

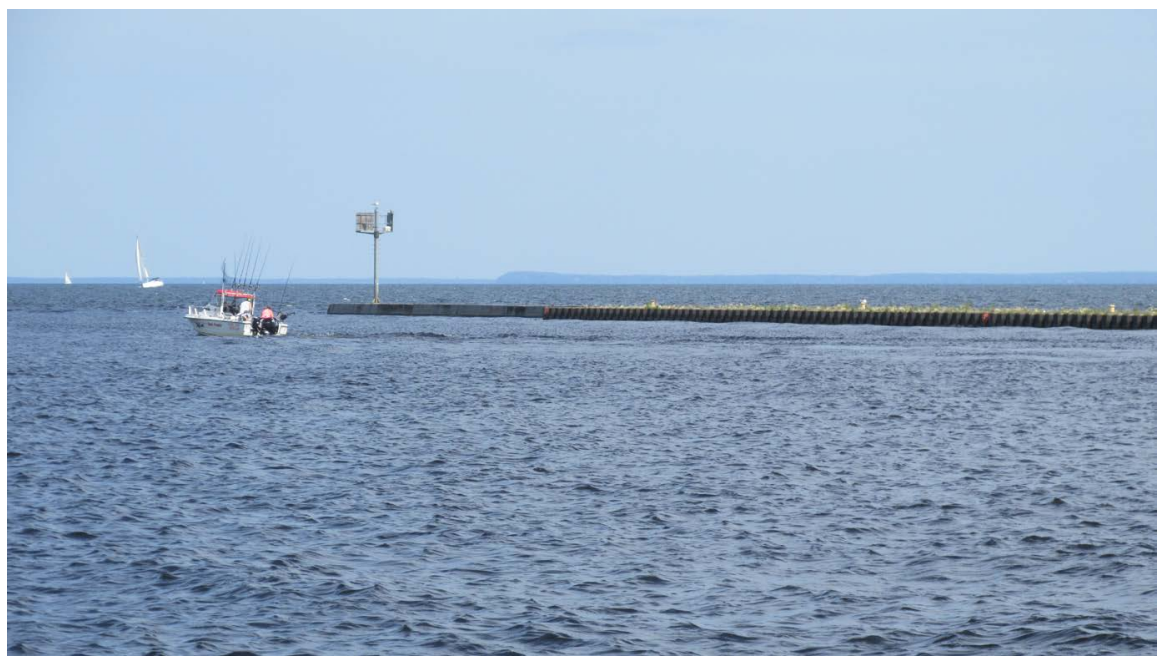

Figure 15. Menominee River break wall extending into Green Bay.

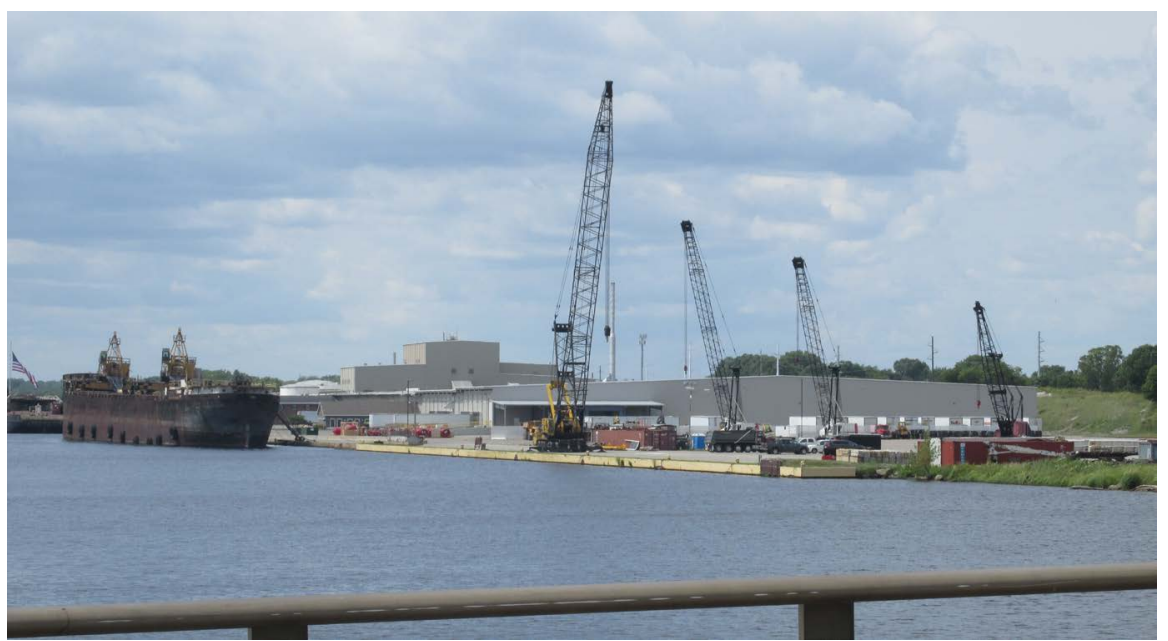

Figure 16. Sea going ship being loaded on the Menominee River at the former Ansul Chemical plant in Menominee, Michigan. 
5.5\% sodium chloride, $4.7 \%$ cacodylic acid (hydroxydimethyarsine oxide), 3.4\% surfactant, $0.5 \%$ antifoam agent, [49]. Arsenicals compose 31.1\% of Agent Blue, $15.4 \%$ is elemental arsenic, in the form of +5 oxidation state arsenical. This means that $4.8 \%$ of Agent Blue has similar properties to arsenate.

In 2009, the Ansul Company operated under two consent orders for environmental mitigation; one from the Wisconsin Department of Natural Resources and another from the U.S. Environmental Protection Agency [2]. In September of 2009, Ansul Company agreed to spend an estimated \$28 million on:

1) Removal $56,600 \mathrm{~m}^{3}$ of arsenic-contaminated sediments from the Menominee River;

2) Construction of an impermeable barrier to bedrock for about $160,000 \mathrm{~m}^{2}$ of sediment;

3) Cap or remove $17,000 \mathrm{~m}^{2}$ of surface soils contaminated with arsenic levels above 16 - 32 ppm;

4) To pump and treat contaminated groundwater;

5) The total remediation costs were: (1) 1976-1984, $\$ 11$ million to pump and treat contaminated groundwater at the southern property border and to install a groundwater interceptor trench [2] in 1998-1999, \$12.4 million to remove arsenic-contaminated sediment from the $8^{\text {th }}$ Street section of the Menominee River (Figure 7 and Figures 15-17); and

6) In addition, an impermeable barrier system was installed to bedrock near the $8^{\text {th }}$ Street slip and adjacent salt vault. In 2012-2013, approximately $\$ 25$ million was spent to dredge and then cap contaminated river sediments due to an EPA order of the removal of 190,000 $\mathrm{m}^{3}$ of sediment from the main channel. The project cleanup began in July of 2012 after Ansul (Tyco) Company hired Stevenson Environmental Services of New York as the general contractor.

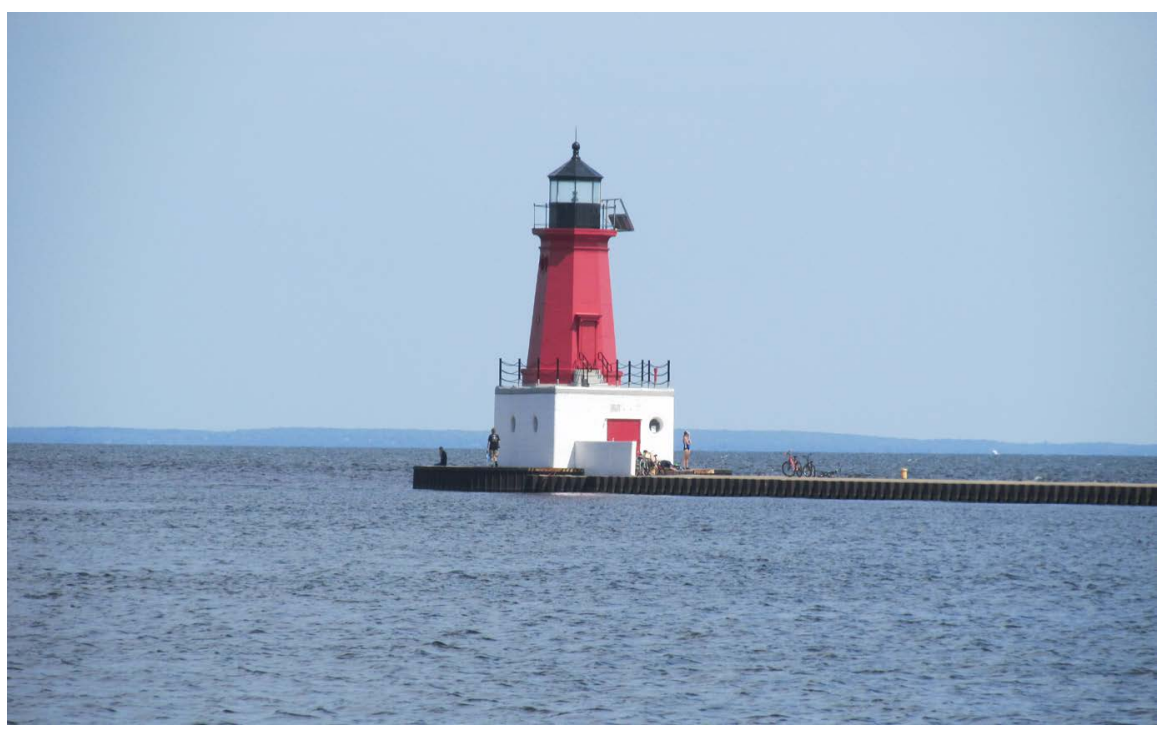

Figure 17. The light house in Green Bay at the end of the break wall in Menominee, Michigan. 


\subsection{Agent Blue as a Defoliant}

The effects of defoliation were studied by comparing soil properties in defoliated and non-defoliated mangrove areas northeast of Nam-Can (Ca-Mau Peninsula) (Figure 10) [18]. The only positive effect was that mangrove area spraying made the areas safer from the NLF by denying cover from within which the NLF could operate and easier to clear land for irrigated fields. However, wood cutters recognized that their primary wood resource was being eliminated.

Within the 10 years, the land impacted or damaged by Agent Blue, primarily rice paddies, totaled nearly 400,000 ha in South Vietnam, mostly near Da Nang and Saigon with over 51,000 ha of forest defoliated at least 4 times and 27,000 ha of mangroves mostly along the South China Sea (Figure 18) were completely destroyed as were 300,000 ha of rice paddies in the Mekong Delta and Central Highlands [50].

\subsection{Military Use of Agent Blue}

The U.S. Department of Army's Chemical Corps Biological Laboratories initiated a major program in 1952 at Camp Detrick, Maryland [51] to develop both the herbicide formulations and aerial spray equipment for potential deployment in Korean Conflict (Figure 19). In 1961, the Kennedy administration approved the Trail Dust (1961-1971) program, which led to formal use of Rainbow herbicides including Agent Blue during the Vietnam War. Herbicides had two primary military objectives: 1 ) to destroy the food crops available to the enemy, and 2) defoliate trees and plants to improve military observation of enemy activity. The program was initially used against both the civilians in the Republic of

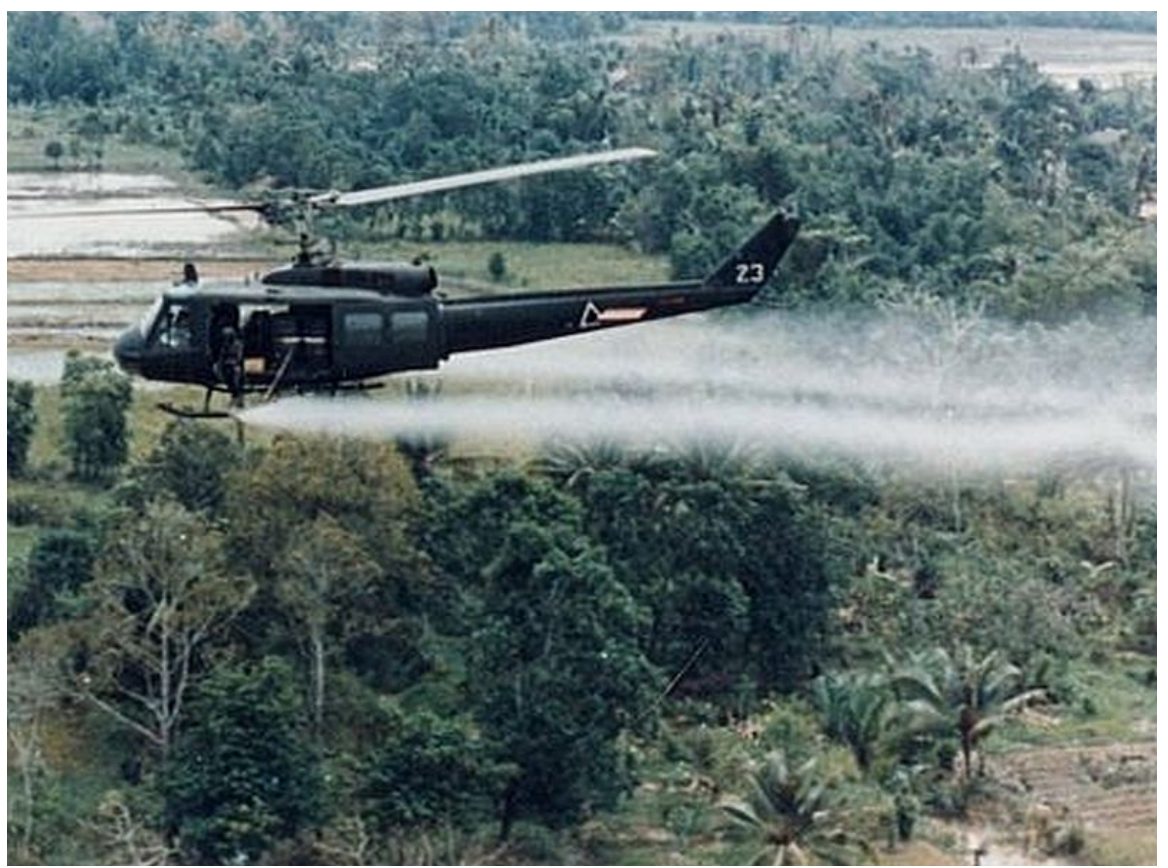

Figure 18. Helicopter spraying Agent Blue on rice paddies and the mangrove forest of the Mekong Delta. 


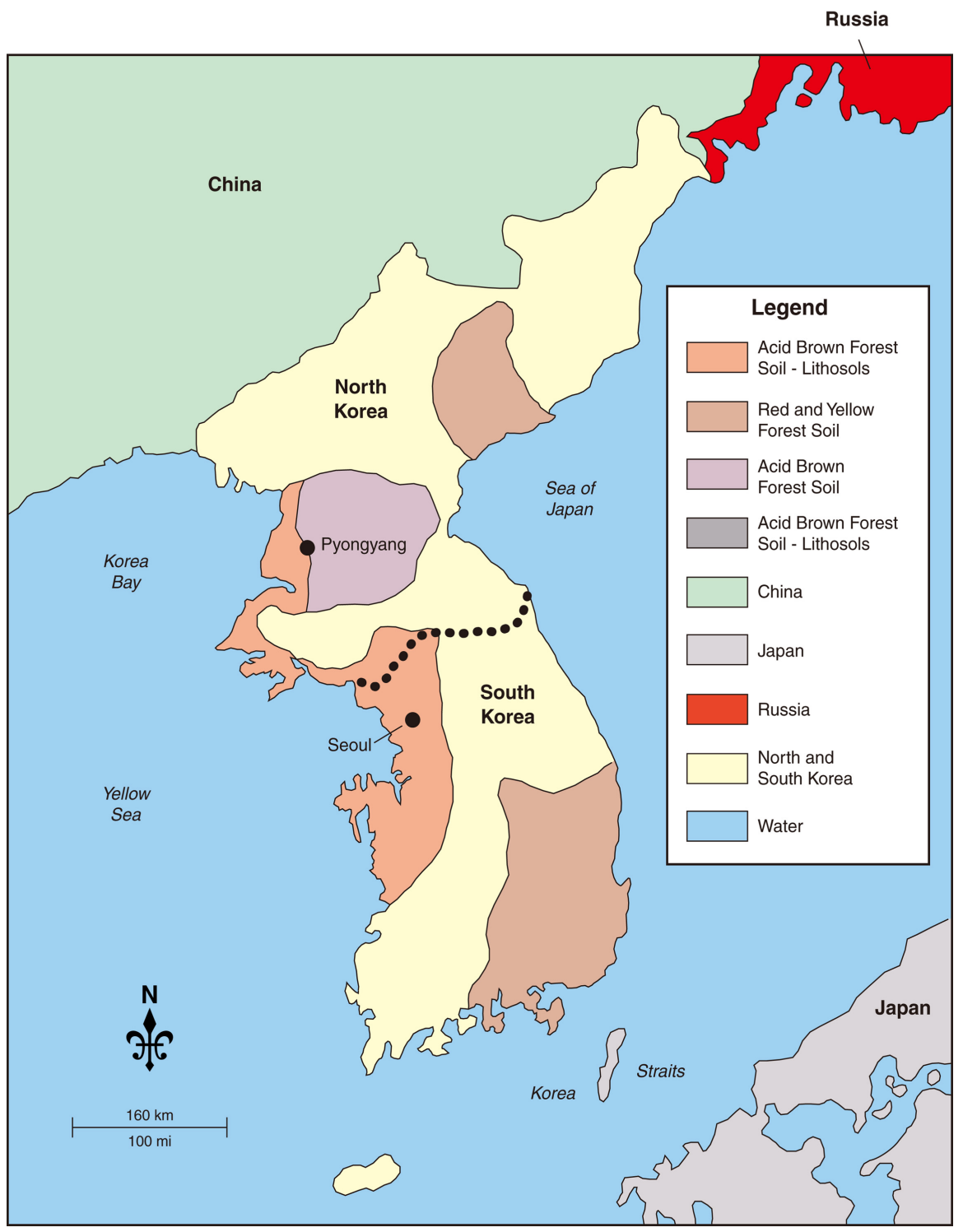

Figure 19. Map of North and South Korea. Map by Mic Greenberg.

Vietnam (RVN) as part of the Diem government's "strategic hamlet" program and against military activities of the National Front for the Liberation of South Vietnam (NLF).

Scientists at Fort Detrick started to test the activity of cacodylic acid used in Agent Blue on rice in 1957. Cacodylic acid in mixtures with 2,4-D and 2,4,5-T was tested in Maryland (1956) Dugway, Utah (1959) and Fort Drum, New York (1960) [52]. Agent Blue $\left(\mathrm{C}_{2} \mathrm{H}_{7} \mathrm{AsO}_{2}\right)$ was first used on the north side of Route 15, northwest of Saigon on 12 January 1962. In addition to Ranch Hand aircraft, the Vietnam Air Force (VNAF) used several H-34 helicopters (Figure 18), and one C-47 aircraft to evaluate applications of the herbicides [52]. Some tests were conducted on the Ca Mau Peninsula (Figure 9) [10]. Rubber vats or fuel bladders filled with Agent Blue were dropped from helicopters on the rice paddies to increase the rice killing efficacy. 
The first Rainbow herbicide barrels started arriving in Vietnam in 1961. Herbicide Blue liquid (later called Agent Blue) was a yellowish-tan liquid that was insoluble in diesel fuel but soluble in water. One gallon (3.9 liters) of Agent Blue contained $1.4 \mathrm{~kg}$ of the active ingredient cacodylic acid. Agent Blue contained both cacodylic acid as a free acid and sodium salt cacodylate. The active ingredients were: $65 \%$ cacodylic acid and $70 \%$ of salt sodium cacodylate [53]. Agent Blue destroyed food crops (rice) by desiccation of the green vegetation making the crop unable to maintain normal photosynthetic activity thereby dessicating the crop and making it susceptible to destruction by burning. These stronger methods were required to overcome the incredible resistance of rice to conventional methods of burning. Herbicides destroyed the food crop fields in $2-4$ days and left the soil unsuitable for further planting within a month. In this way, the Republic of Vietnam and United States militaries ultimately destroyed at least 300,000 ha of food crops (rice) [53].

Agent Blue, a "rainbow herbicide" used by the United States military during the Vietnam War, was inspired by the British use of herbicides and defoliants applied during the Malayan Emergency (1950s) to provide a legal cover for its use. Destroying rice to prevent its consumption by the enemy was a U.S. and Republic of Vietnam military strategy at the very start of U.S. military involvement in Vietnam War.

Initially, Republic of Vietnam and United States soldiers attempted to blow up dikes and raised borders around rice paddies to dry them up by using mortars and grenades. However, mature rice grains are very durable and not easily destroyed even if the rice crop is dried up by paddy drainage. Every grain of rice that survived became a seed to be collected and re-planted. The U.S. military discovered that rice grain is one of the most difficult plant substances to destroy. Even thermite metal grenades could not make it burn and when the rice is scattered it can be collected or harvested and replanted by the Vietnamese. If an herbicide like Agent Blue is applied by spraying before the rice plants are mature it can mean a $60 \%$ to $90 \%$ rice crop loss. If subsequently burned the immature rice seeds could be destroyed. However, the burning of As treated vegetation resulted in the release of volatile As-containing aerosols and ash into the atmosphere. Surviving rice was contaminated, as well, with trace amounts of arsenic. Rice grown in the Vietnam is to this day still tainted by trace amounts of arsenic probably from both anthropic and natural sources.

At the end of 1967 an International War Crimes Tribunal stated that: "The soldiers discovered that rice is one of the most maddeningly difficult substances to destroy, using thermite metal grenades it is almost impossible to make it burn and, even if one succeeds in scattering the rice, this does not stop it being harvested by patient men". The U.S. and South Vietnamese military went to "bigger and better" options that would actually destroy the entire rice paddies. The purpose of Agent Blue was to desiccate and kill narrow-leaf plants and trees (bamboo (Figure 20), grass, rice (Figure 21), and bananas). "Operation 


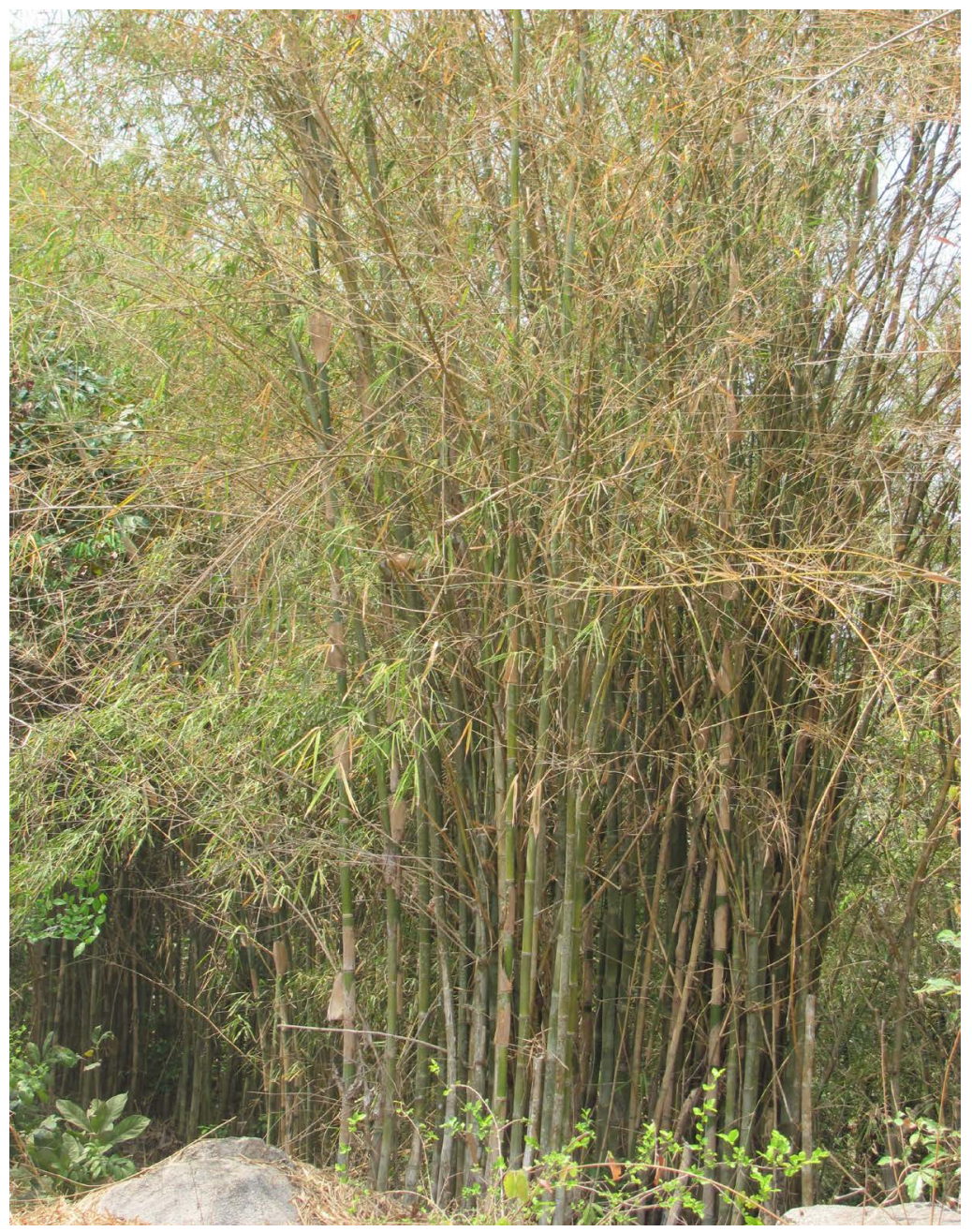

Figure 20. Bamboo growing in Mekong Delta.

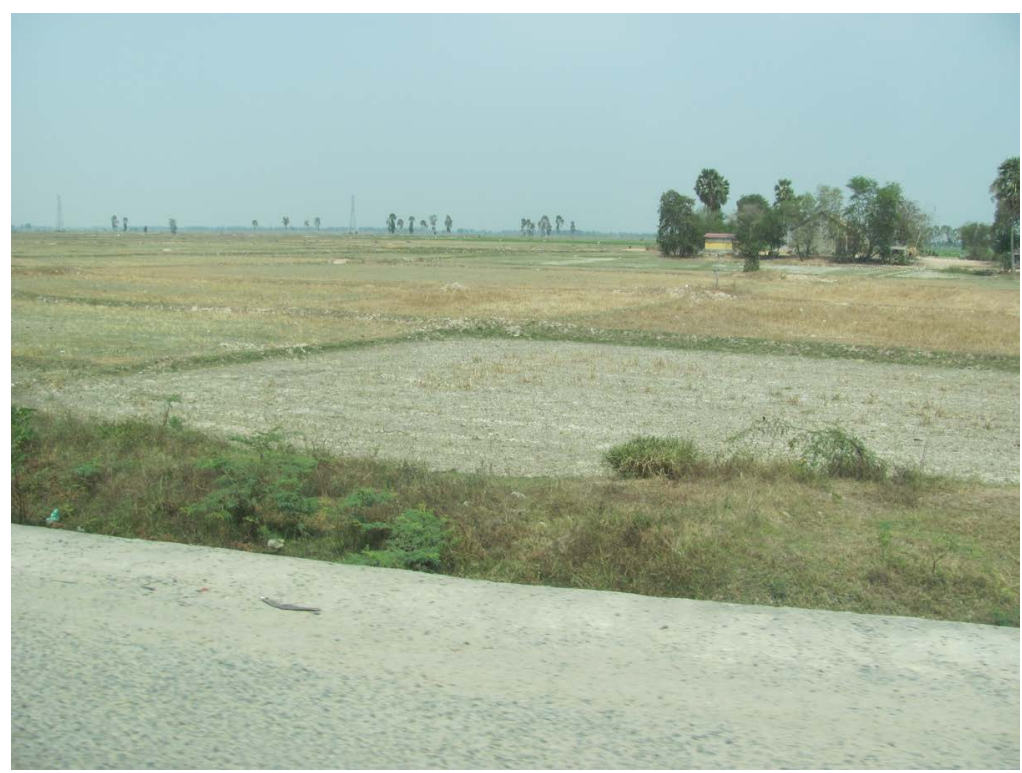

Figure 21. Rice residue in dried out fields similar to the rice paddies sprayed with Agent Blue in the 1960s and 1970s. 
Ranch Hand", was militarycode name for spraying of herbicides by U.S. military aircraft in Vietnam and Laos from 1962 through 1971 [53]. In this case the widespread use of Agent Blue by the Republic of Vietnam and United States militaries was an attempt to take away the enemy's food supply by depriving them of food resources.

Fewer 208-liter Agent Blue barrels with a blue stripe were sent to South Vietnam than Agent Orange with an orange stripe. Between 1961 and 1971, the U.S. used an estimated 7.8 million liters of Agent Blue herbicide (1,132,400 $\mathrm{kg}$ of As) was applied as a chemical weapon for "crop destruction and defoliation" which fell primarily on the mangroves, rice paddies, and the surrounding forest of South Vietnam, but was eventually also used in Laos along the Ho Chi Minh trail to kill crops and upland rice in the Central Highlands in order to deprive the North Vietnamese communist insurgents troops of a food source. Agent Blue was sprayed on South Vietnam upland and lowland rice paddies to deprive the insurgents of the valuable staple food crops the plants provided. The Agent Blue was applied at the average rate of $2.831 \mathrm{~kg}$ As/ha for the total rice paddy and forest area. Many areas were sprayed only once while other areas received four or more applications. The forest and mangrove areas were usually sprayed at a different rate than the rice paddies. Unable to control the insurgent's access to their food supplies or eliminate their grassroots village support, the U.S. military response was simple: "If you cannot control it, kill it" [54] [55].

Agent Blue was primarily used to defoliate narrow grass vegetation or to kill food crops by desiccation. The rice plant is highly dependent on water to survive. Spraying Agent Blue on paddies can destroy approximately $60 \%$ of an entire rice paddy and leave it unsuitable for intermediate re-planting. The dried rice paddy vegetation and seeds were then cleared by burning. Rice-killing military operations also included use of specially designed rubber or plastic fuel bladders that were probably dropped from helicopters (Figure 18) into rice paddies which burst on impact to release the toxic Agent Blue herbicide [55]. This usually resulted in (100\%) of rice crop being destroyed [55]. Bladders of Agent Blue were also dropped into the water irrigation canals which ruptured on contact and contaminated the water in the rivers, canals and rice paddies. After the war, the Vietnamese people would then harvest and eat the tainted rice, fish and shrimp for the next 55 years. One can only imagine what happened to the Vietnamese working in the rice paddies when bladders full of Agent Blue exploded on impact.

\subsection{Agent Blue Use in South Vietnam}

The use of herbicides in South Vietnam was begun as an initiative of South Vietnam President Ngo Dinh Diem. Part of the Vietnam government's policy was to move the rural population into "strategic hamlets" that could be more easily secured and defended than the existing villages. This also allowed the destruction of the rice crops and deny the NLF and insurgents food sources in the 
rural areas to discourage their military activities. He insisted that Agent Blue be used and President Kennedy finally gave the okay for testing Agent Blue on crops in South Vietnam [56]. According to Lindsey Arison III in his report "The Herbicidal Warfare Program in Vietnam, 1961-1971". The RAND Corporation in 1967 opposed the use of herbicides, especially Agent Blue. Eventually spraying the rice paddies to starve the enemy was determined to be a mistake since there was a sufficient rice supply in South Vietnam to feed everyone [56].

On 9 January 1962 the first shipment of sodium salt of cacodylic acid and code-named "Blue" were received at Tan Son Nhut Air Base, Republic of Vietnam. The blue colored bands, which were painted around the centers of the 208-liter drums, served as an identification aid for support personnel. Agent Blue was the first rainbow herbicide used in Operation RANCH HAND, the tactical military project in South Vietnam for the aerial spraying of herbicides [57] [58].

The early 1960s South Vietnam's Agent Blue program, known as KhaiQuang Program, was designed to make battlefield more visible as well by clearing foliage leaves and eliminate the food crops. Agent Blue missions required handlers dressed in civilian clothing, aircraft without U.S. Air Force markings and if U.S. military personnel were captured the U.S. Government would not acknowledge the crew as members of the U.S. military [54] [55]. There were no warnings or safety equipment provide to the U.S. military handlers of Agent Blue; however, most of these were Vietnamese military personnel. Nor were the Vietnamese warned against drinking the water from rivers where Agent Blue as well as Agent Orange were sprayed [4] [59]. No Vietnamese civilians or military personnel knew about the contamination or the inherent health hazards of the chemical herbicide, Agent Blue that they were handling.

President Kennedy's Joint Chiefs of Staff stated in the early 1960s that "care must be taken to assure that the U.S. government does not become an international target for charges of employing biological or chemical weapons". International repercussions against the U.S. could become significant [60]. After considerable internal debate, President Kennedy gave the approval needed to use Agent Blue on food crops including rice. The HERBS collection [4] [59] suggests 4,712,000 liters (664,392 kg As) of Agent Blue were sprayed in South Vietnam (another source, Institute of Medicine, suggests 7.8 million liters $(1,132,400 \mathrm{~kg}$ As) were used from 1961 to 1971) [60]. However, the South Vietnam military, even with U.S. assistance, was unable to control their grass root village support nor the Viet Minh's access to food supplies.

The first recorded use of Agent Blue by the U.S. military was in November of 1962 with 4.6 million liters sprayed or dumped (664,392 kg As) during the next nine years. This was in addition to the 3.2 million liters (468,008 kg As) was sprayed by the Republic of Vietnam military (secret mission and an estimate since official records are not available or probably not kept or if kept not retained). New studies of U.S. military flight logs suggest an even greater use of 
Rainbow herbicides including Agent Blue. Killing of rice was a military strategy from the very start of the U.S. participation in American Vietnam War.

\subsection{Anthropogenic Sources: The Vietnam War}

The Vietnam War's “Operation Ranch Hand” may have contributed to the crisis of arsenic contamination in Southern Vietnam upland and lowland rice paddies. However, the NAS [44] findings suggest arsenic levels were still below WHO standards. Fortunately, South Vietnam had not started pumping the groundwater for rice paddies or shrimp ponds. The goal was to clear out crops and foliage to improve military intelligence, achieve enhanced security, increase availability of troops used for combat, reduce cover for enemy resistance, and reduce United States personnel casualties [3]. Between the first test in Kontum base in southern Vietnam on August 10, 1961 and October 1971, rainbow herbicides including Agent Blue were shipped to and sprayed all over South Vietnam [4] [58].

\subsection{Agent Blue Field Studies and Application in South Vietnam}

A study done by Watson et al. [59] found that life expectancies of animals exposed to Agent Blue were reduced to less than ten percent of the unexposed animal population. The lethal concentration for rats of Agent Blue is $3.5 \mu \mathrm{g} / \mathrm{L}$. Soldiers with prolonged exposure to Agent Blue had a garlic odor in their breath which is one of the common noticeable symptom of arsenic poisoning. Research shows the human liver absorbs $40 \%$ of the cacodylic acid [60]. The extreme levels of arsenicals and high bioaccumulation of arsenicals in the body are detrimental to crops and human health.

Military personnel applied Agent Blue by using hand sprayers on back packs, trucks (Figure 22), helicopters (Figure 8) and river boats or dropped in fuel bladders on rice paddies and adjacent canals. In some cases, Agent Blue was also used to kill bamboo. The military personnel was told that the herbicides including Agent Blue were harmless and the herbicide handlers including Vietnamese soldiers and civilians did not need to wear protective gear such as facemasks, googles, gloves and suits. The Agent Blue often came in contact with the skin of the military personnel who were spraying Agent Blue. The military personnel involved in Operation Ranch Hand were in 3 risk categories separated by the level of potential danger to herbicides including Agent Blue. Navigators, co-pilots and pilots were thought to be at low risk for exposure and contamination. At moderate risk group included the military personnel who loaded the herbicides or re-drummed the herbicides (Figure 23), the crew chiefs, the mechanics and personnel who repaired the tanks and spray equipment. The high-risk group included the flight engineers who operated the spray equipment. However, often unrecognized herbicide contact victims were the aircraft and crews of fire support and escort aircraft which often had to maneuver around the spray aircraft to suppress ground fire and ended up flying through the spray stream or spray drift without protective gear. The empty Agent Blue barrels were 


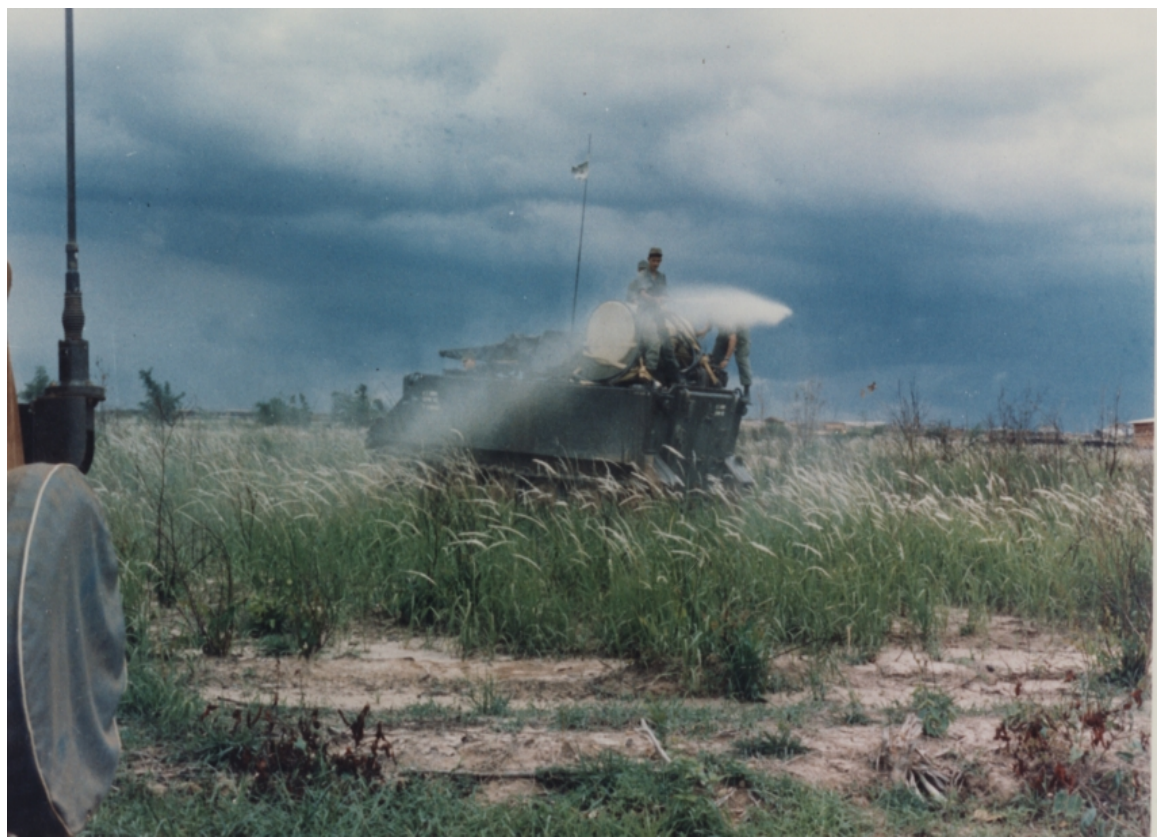

Figure 22. Rainbow herbicides sprayed from a M113 Armored Tracked Personnel Carrier.

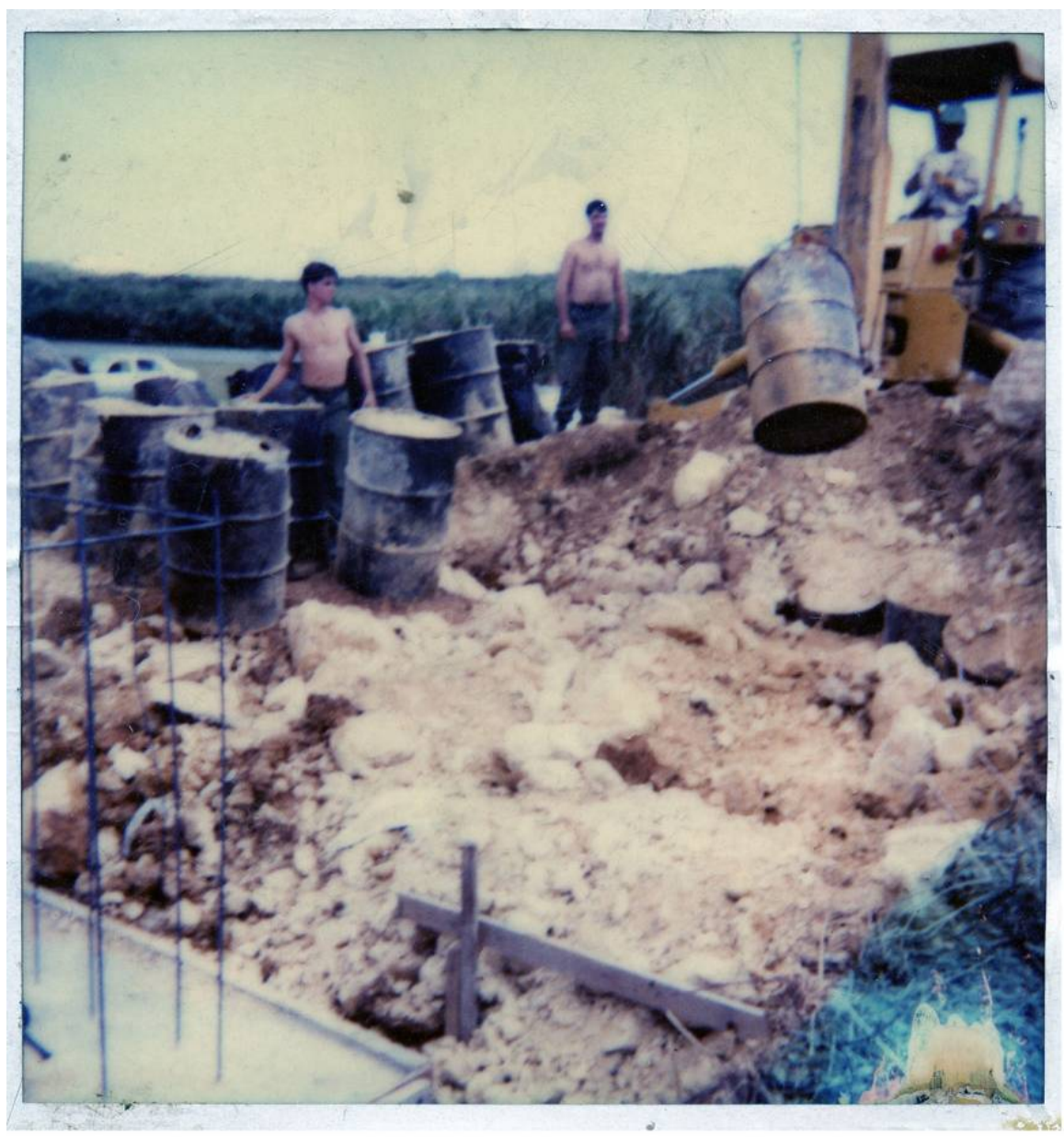

Figure 23. Repacking herbicide barrels and recovering buried barrels leaking into the ground. 
washed and poured out on the ground (Figure 23) by hand often without protective gear and then re-purposed for improvised showers, to store drinking water or even as barbeque pits or even sold to locals. The rinse water from cleaning the barrels was poured on the soil surface and either leached into the soil and groundwater or was transported off-site during monsoon rains into the waterways.

Agent Blue harmed village food supplies and forced many rural villagers into the "strategic hamlets" or urban slums after destroying hundreds of paddies with arsenic laced Agent Blue. Alain C. Enthoven, assistant secretary of the defense (DOD) for systems analysis, reviewed the RAND report concluded that "the existing wholesale food crop destruction program was counterproductive because it alienated the affected South Vietnamese population without denying food to the communist insurgents". But others responsible for U.S. military strategists did not agree.

\subsection{Use Patterns of Agent Blue Herbicides}

Approximately 50\% of all Agent Blue was used in rice-destruction missions in Mekong Delta and Central Highlands with the remainder being used in enemy or remoted controlled areas and as a contact herbicide for control of grasses around base perimeters [57]. The total quantity of herbicides disseminated in South Vietnam is uncertain. Procurement records account for 4.7 million liters (664,392 kg As) of Agent Blue and 981 missions. The Institute of Medicine [61] suggests the amount of Agent Blue sprayed or dropped was actually closer to 7.8 million liters $(1,132,400 \mathrm{~kg}$ of As) on 400,000 ha. The remaining missions and liters of Agent Blue herbicide were either used early in South Vietnam military operation prior to the start of the Vietnam War (1962 to 1965) or were incompletely documented [4] resulting in discrepancies in reported quantities of material used [61].

Prior to 1962, a large and useful amount of published information about woody species vegetation control existed in publications oriented to provide information and a knowledge base for herbicide use in American agriculture. The availability of the information encouraged the use of herbicides in South Vietnam to remove foliage along thoroughfares, defoliate areas surrounding bases (Figure 24) and communication routes, improve visibility in heavily canopied jungle, and destroy enemy subsistence crops. The recommendations in the available publications resulted in the chemicals of choice to be the phenoxy and arsenical herbicides.

\subsection{Effect of Spraying of Rainbow Herbicides on South Vietnam Environment and Food Supply}

Herbicide damage effects include: 1) loss of potential production at a plant stage before the growth becomes economically valuable, and, 2) loss of commercial products such as grain, timber and fruit and lack of young plants including 


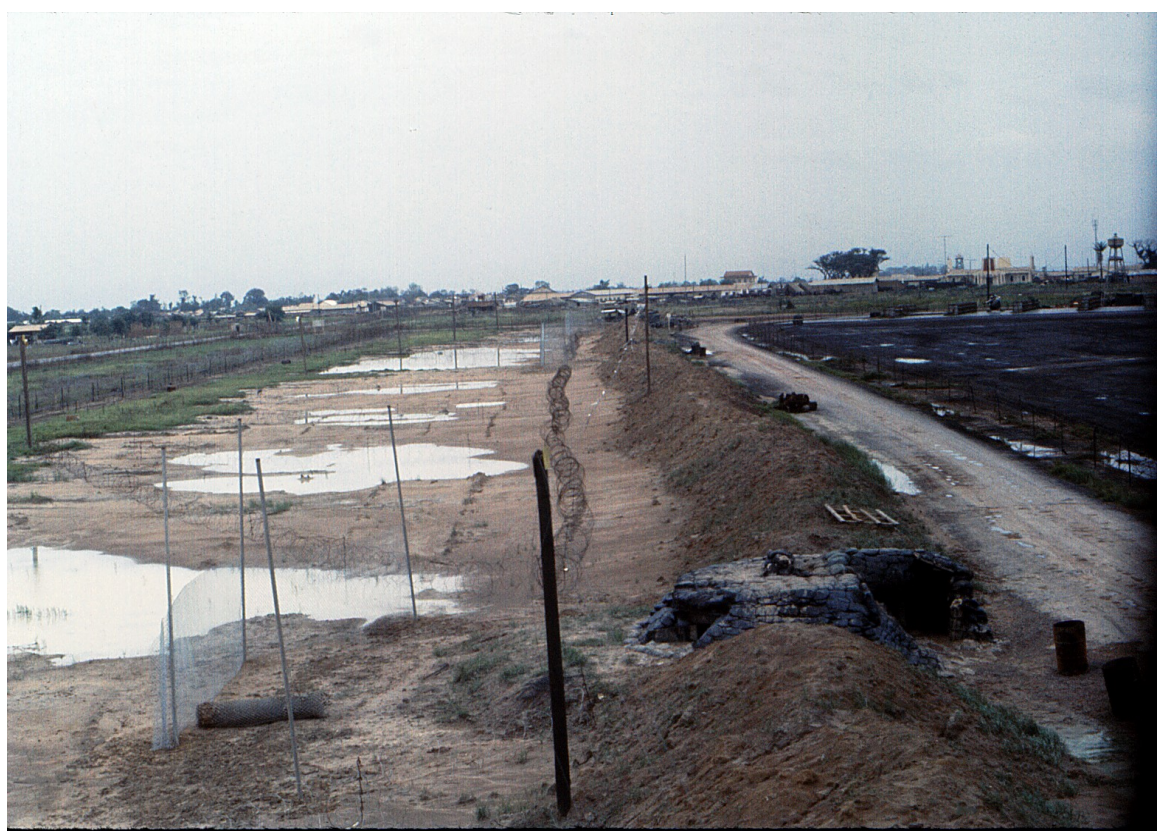

Figure 24. Defoliated perimeter fence at a military base in Vietnam that were sprayed with Agent Orange and Agent Blue to kill the jungle vegetation. Picture was taken by U.S. Army Flight Operations Specialist 4 John Crivello in 1969.

seedlings and seeds required to maintain food production. The effects of crop damage were obtained mainly by studies of rural settlements and from interviews with villagers. The results were reported under the "Effects of Herbicides and Humans". Human reactions to military spraying of Rainbow herbicides were included in studies on mangrove forests (Figure 18) and Vietnamese and Montagnard rice paddies (Figure 25), coconut plantations (Figure 26), gardening and upland crop areas) [44].

After spraying, individuals in every community interviewed reported of domestic animals (Figure 27) and humans who became ill or died after Rainbow herbicides were sprayed or the eating of herbicide-treated plants or drinking contaminated water. Thus, Rainbow herbicides were destructive to livelihoods of the people whose land was sprayed.

\subsection{United States Scientists Protested the Use of Rainbow Herbicides in Vietnam War}

In 1965, at the start of the American Vietnam War, Dr. Arthur W. Galston (1943 $\mathrm{PhD}$ in Botany from University of Illinois) who made the key scientific discovery [62] that made Agent Orange possible, joined a group of scientists who were protesting the use of chemical weapons in Vietnam War including the Rainbow herbicides [62] [63] [64] [65] [66]. Many of the herbicides were untested and being applied in massive quantities. At the August 1966 annual meeting of the American Association of Plant Physiologists, Dr. Galston (then a Department Head at Yale) prepared a resolution [62] that was subsequently passed and sent as a petition to President Lyndon Johnson. The letter warned of the defoliants 


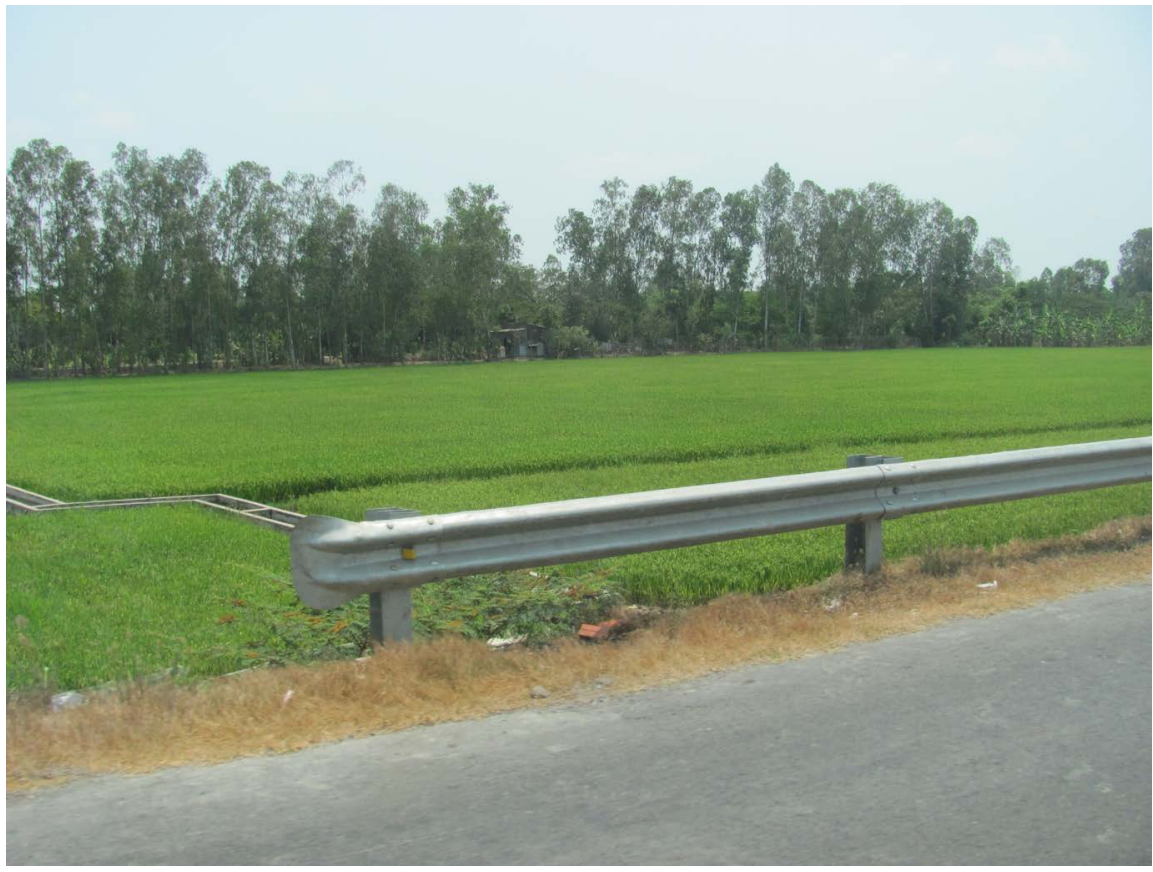

Figure 25. Vietnamese and Montagnard rice growing in the Mekong Delta of Vietnam.

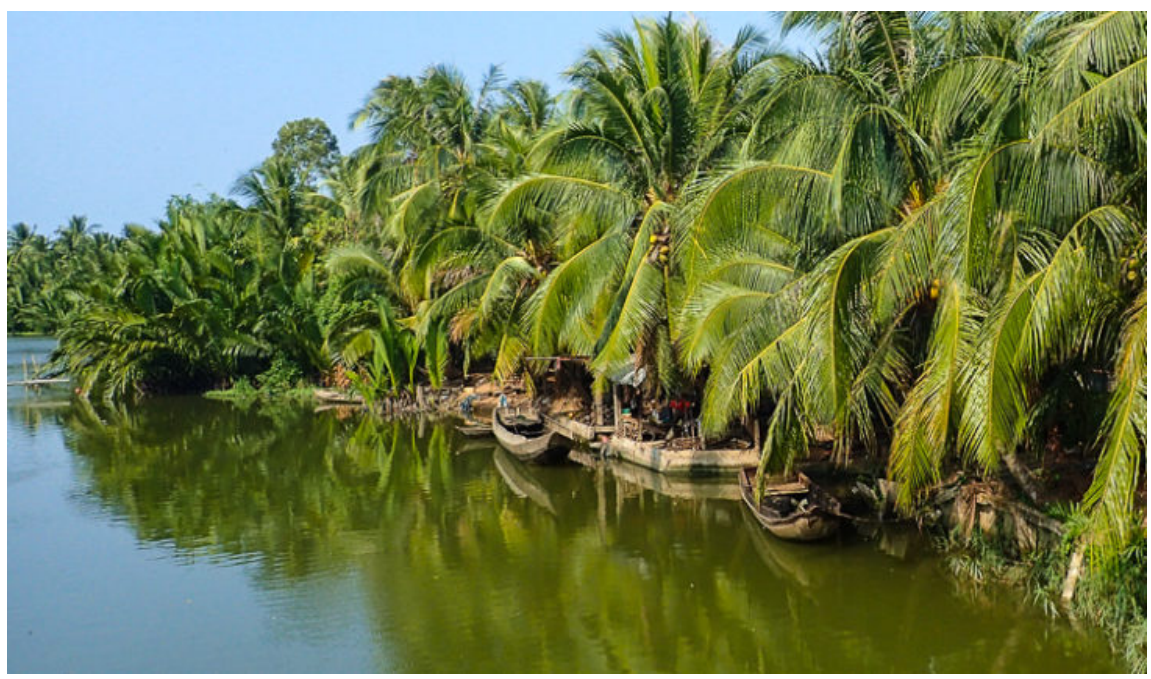

Figure 26. Coconut plantations in Mekong Delta along a branch of the Mekong River.

potential to cause immediate and long-term ecological, animal and human harm. The letter stated that the destruction of food crops would eventually affect the Vietnamese civilian population including women and children not actively involved in the war. The petition failed. However, Dr. Galston and other scientists, continued to lobby the Department of Defense (DOD) and the U.S. government to stop the use defoliants in South Vietnam. They also recommended toxicological studies of the Rainbow herbicides.

At the start of the American Vietnam War (1965) the United States public began to immediately question the progress in the Vietnam War and the U.S. military strategy and tactics. The DOD ordered an investigation [44] of the 


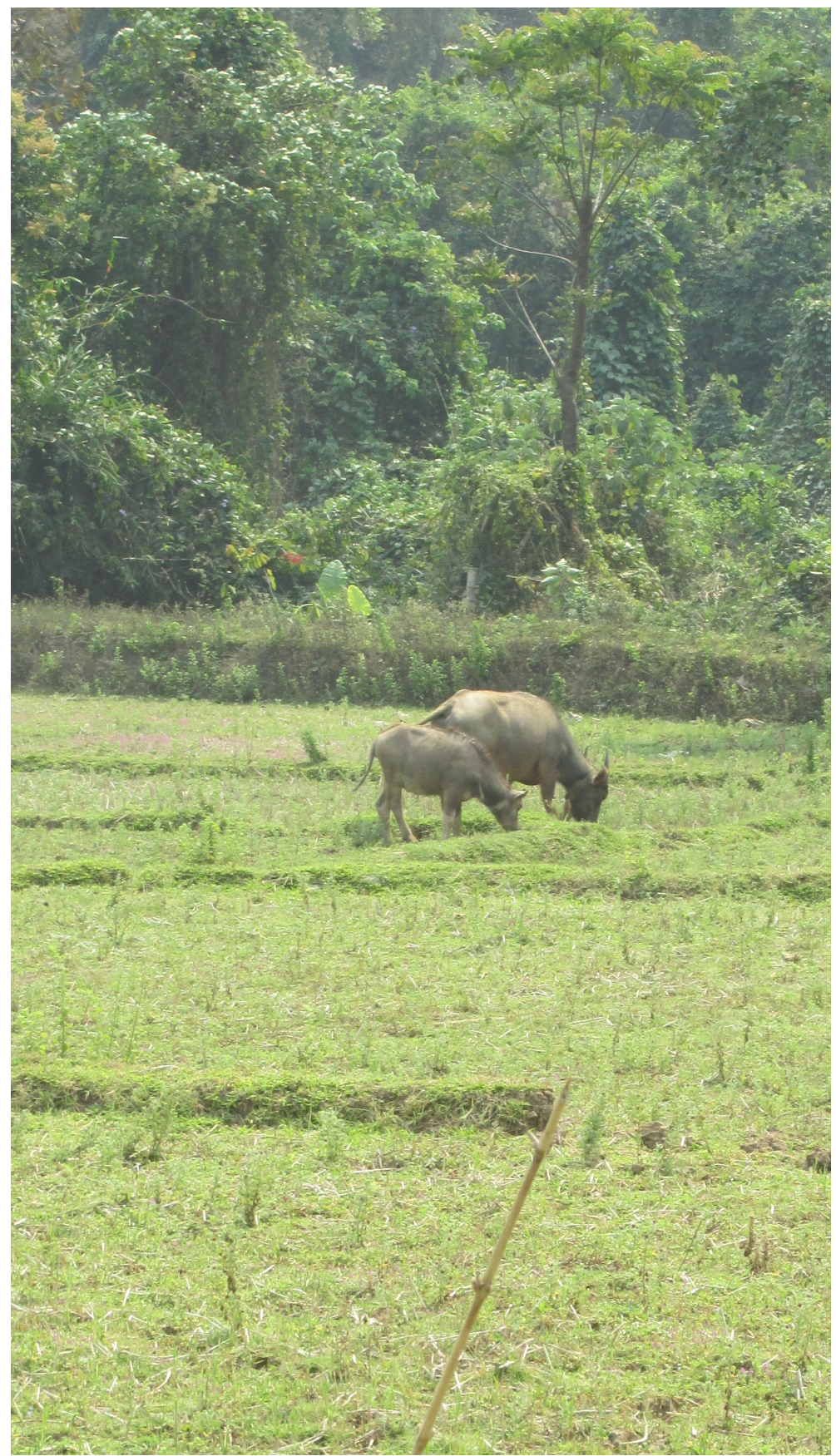

Figure 27. Water buffalo in rice paddy in Mekong Delta of Vietnam.

sprayed defoliants (from 1962 to 1965) and their possible links to mutations, cancer and birth defects. In 1966, Bionetics Laboratories headquartered in Los Angles, California, reported to the U.S. Surgeon General's office that one active component in Agent Orange, 2,4,5-T contained a contaminate (or by-product) called 2,3,7,8-tetrachloro-dibenzo-para-dioxin or dioxin TCDD. In studies, small doses of TCDD caused birth defects in pregnant rodents. Large doses resulted in still born or mutation in offspring. Later research showed dioxin TCDD to be extremely toxic organic compound, and linked to serve cancers, skin diseases 
and birth defects.

Dr. Galston and Matthew Meselson (Harvard), with former connections to Cal Tech [66], presented the information to Dr. Lee A. Dubridge, a former colleague from Caltech, and science advisor to U.S. President Richard Nixon. President Nixon subsequently terminated the U.S. military policy of developing and spraying Agent Orange, called Operation Ranch Hand, in 1970 and the other 5 Rainbow herbicides in 1971.

Approximately five thousand scientists including members of the American Association of Plant Physiologists, the American Association for the Advancement of Science, and the Federation of American Scientists, which included seventeen Nobel Prize winners, re-petitioned the U.S. government and military to stop the use of biological and chemical weapons including the Rainbow Herbicides [62] [63] [64] [65] [66]. In 1971, President Nixon, acting in his role as Commander in Chief, ordered the U.S. military to stop spraying all Rainbow herbicide (the spraying of Agent Orange had been stopped in 1970) [44].

\subsection{NAS [44] Damage Assessment Study and Findings}

National Academy of Sciences (NAS) PL 91-441. A NAS study was authorized by an Act of Congress, Public Law 91-441, Fiscal Year 1971 Military Procurement Authorization Acct Section 506-9c. Secretary of Defense was required to make arrangements with the NAS to do a comprehensive study and investigate: (1) physiological and ecological dangers in inherent use of defoliation program by Department of Defense in South Vietnam, the NAS [44] study started in Sep. 1971 to Sep. 1973. NAS scientists spent 1500 scientist days working in Vietnam during the Vietnam War and found it an impossible to determine whether arsenic found in the rice paddy soils was from the herbicide spraying of Agent Blue, from other sources, or was present naturally in the soil prior to the spraying.

The NAS over flight on January 27, 1972 of the Song-Re Valley, Quang-Nyai Province of an area sprayed with Agent Blue on August 9, 1970 found that rice fields and vegetable plots appeared normal from the low flying aircraft. NAS [44] analyses of small number of samples of fish, rice, shellfish (Figure 28), worms, soils and water collected near a community in Rung Sat which had Agent Blue missions between 1964 and 1969 found the arsenic levels within the normal ranges.

NAS scientists studied the efforts of Agent Blue on settlements by interviewing the villagers and reported their findings in a report entitled "Effects of Herbicides on Humans" NAS [44]. Human reactions to military spraying of Rainbow herbicides was documented. Herbicide spraying including Agent Blue resulted in the displacement of people from their rural homes into government sponsored villages as part of the Diem government's "strategic hamlet' policy or urbanization due to movement into the slums of Saigon and other larger cities. Only 1 of 18 rural areas increased in population and settlement during the 


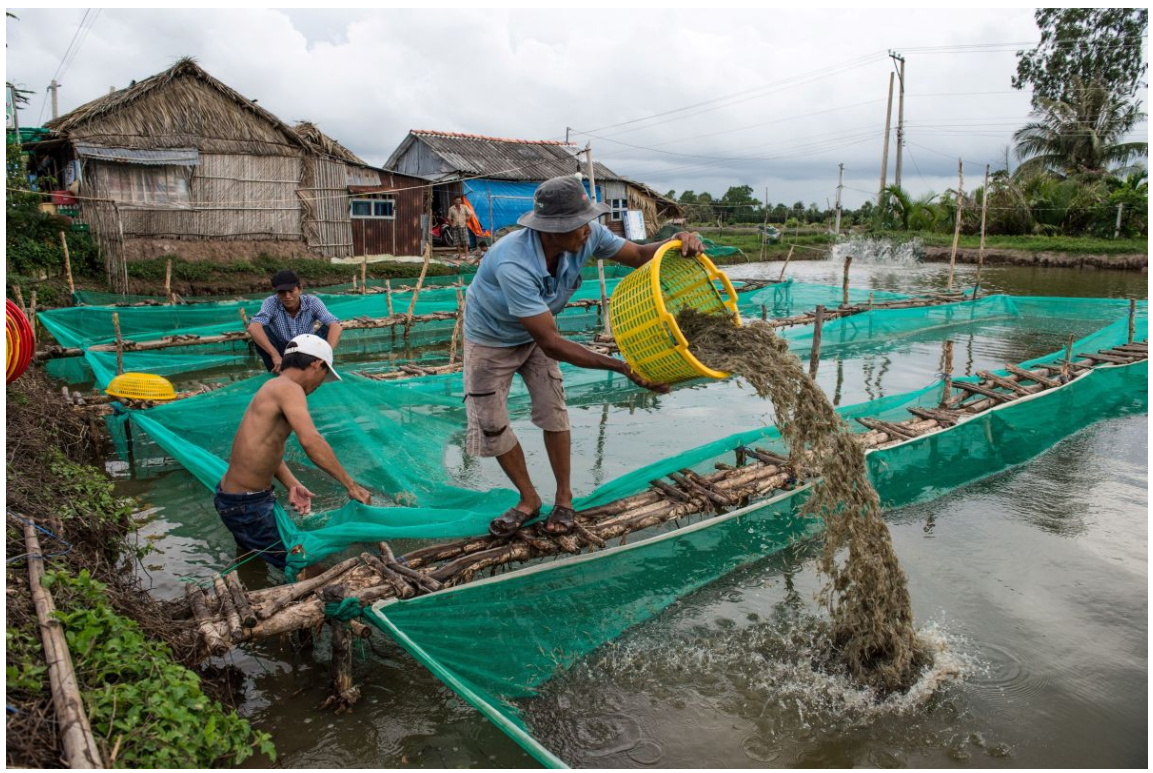

Figure 28. Shrimp farm in Mekong Delta of Vietnam that was developed after 1975.

1960s. After spraying of Rainbow herbicides and subsequent burning of crops, individuals in every community interviewed reported on who became ill or died after the spraying, or as a result of eating of herbicide-treated plants or drinking contaminated water. The NAS [44] report was translated into Vietnamese for the locals to read. Vietnamese had to live with the consequences and had to undertake remedial action. Financial and technical support from the U.S. (funds, and training for Vietnamese workers) and lent professional technical personnel and supplied equipment.

U.S. and Vietnam public concerns:

1) Did the extensive use of Rainbow herbicides including Agent Blue modify the environment of Vietnam beyond the point of recovery? Agent Blue did not raise the arsenic levels in the groundwater above the 1970s drinking water standards [44]. However, during the next 50 years the dioxin TCDD hotspots (all of the Rainbow herbicides except Agent Blue contained dioxin TCDD) did not recover naturally and DOD cleanup was required at Da Nang, Bien Hoa Air Force Bases and other dioxin TCDD hotspots in South Vietnam.

2) Damage to crops and forest caused a major economic loss. Was there evidence of a correlation between exposure to herbicides and congenital malformations, human reproductive failures, and genetic damage? There were many spikes in the arsenic levels (above WHO standard) in the Mekong Delta groundwater. Arsenic was bioaccumulated in the Vietnamese as a result of elevated arsenic levels in the drinking water and food supply. Medical evidence collected from U.S. veterans and Vietnamese and their offspring during the next 50 years suggests there was significant genetic damage.

Meanwhile, the effects of herbicide damage were: 1) the loss of potential food crop production at a stage before maturity and becomes economically valuable, and 2) the loss of commercial products such as grain, timber, fruit, seedlings and 
seeds required to maintain food production.

\subsection{Impacts on Mangrove Forests}

NAS [44] studied the effects of defoliation by comparing soil properties in defoliated and non-defoliated mangrove areas northeast of Nam-Can (Ca-Mau Peninsula) (Figure 10). The only positive impacts recognized came from the spraying of the mangrove area, which increased security from the NLF and it became easier to clear land for irrigated fields. However, wood cutters recognized that their primary resource was being eliminated.

\subsection{Impact of Agent Blue on Human Health}

Drinking water and rice are considered the two major pathways to potentially high daily levels of As intake [22]. Vietnamese military, farmers and civilians were at risk of As exposure from As contaminated groundwater supplies, long-term diets of daily rice with high levels of As, and rice and vegetable crops produced in soil with high As concentrations. Water and food supplies were critical to U.S. and South Vietnamese military and Vietnamese civilians during the Vietnam War.

Arsenic toxicity and health effects are complex and the impact of Agent Blue on human health was not well known for many years. Post-Vietnam War, arsenic-based industrial wood preservatives and herbicides with cacodylic acid were used throughout the U.S. in wood products, golf course management, cotton fields and drying out agricultural plants prior to harvesting [67]. Today, none of these are commercially available with the exception of the weed killer monosodium methanearsonate (MSMA) for use on U.S. cotton [67]. The frequent use of manufactured arsenic products in industry and agriculture has resulted in human exposure by way of inhalation, contaminated drinking water, and food. Epidemiological evidence and animal studies show excessive risks of lung and skin cancers as well as delayed health effects at relatively high exposure rates [68].

The spraying of arsenic-based Agent Blue was field tested in United States, Puerto Rico, Canada and Thailand. Often, Agent Blue was used at full strength during the Vietnam War. The Cancer Assessment Group of EPA currently puts arsenic in the top category of cancer-causing chemicals. Arsenic, even at low doses has been found to be responsible for lung, bladder, and liver cancer and the arsenic is able to cross the placenta to create cancers in the fetus as well as both birth defects and childhood cancers have been linked to arsenic. The effects of arsenic are delayed and can take decades to appear in humans. Arsenic can cause damage to human DNA which can adversely impact future off-spring. Arsenical herbicides containing cacodylic acid as active ingredients and are still used today as weed killers and crop desiccants. Less toxic formations of arsenical herbicides sold over the counter today can cause headaches, vomiting, dizziness, profuse and watery diarrhea, followed by dehydration, electrolyte imbalance, 
and gradual fall in blood pressure, convulsions, stupor, general paralysis and possible death in 3 to 14 days [60].

Sodium cacodylate is regarded as a Special Health Hazard by the New Jersey Department of Health and EPA. The Agency for Toxic Substances and Disease Registry suggests "Arsenic cannot be destroyed once added to the environment", so the arsenic amounts $(1,232,400 \mathrm{~kg}$ of As) U.S. and Republic of Vietnam militaries added when spraying or dumping Agent Blue during the Vietnam War, to the arsenic load in Mekong Delta and South Vietnam environment. The arsenic caused additional health effects in humans and animals. Water soluble arsenic can get into the surface water, soil and groundwater from applications of Agent Blue on the rice paddies. After the Vietnam War vast amounts of arsenic laced groundwater was pumped to the surface for rice paddies, shrimp ponds and for the water needs of the 15 million people living on the Mekong Delta.

\subsection{National Academy of Sciences Report: 1974 Summary and Conclusions}

For the last 46 years the NAS [44] Part A: Summary and Conclusion report appears to have been the "final word" on the fate of Agent Blue and its active component cacodylic acid. Cacodylic acid breaks down in the soil and thought to bind tightly as arsenate $(+5)$ to soil compounds. In our paper we explain that the arsenic exists in four forms including two water soluble forms arsenite $(+3)$ and arsenate (+5), which is a water soluble arsenic salt, and much of the water soluble arsenic was not tightly bound and leached from the rice paddy and root zone into the Mekong Delta or Central Highland groundwater potentially contaminating the groundwater. The arsenic rich groundwater (from natural and anthropic sources) was then pumped back (after 1975) to the surface by hundreds of thousands of tube wells and the water was then used for rice paddies, shrimp ponds and to meet the drinking water and household water needs of 15 million Vietnamese living on the Mekong Delta and in the Central Highlands.

The National Academy of Sciences Part A: Summary and Conclusions report [44] states: "Cacodylic acid, the active component in Agent Blue, is a non-selective herbicide killing a wide variety of herbaceous plants. It is a non-volatile, highly soluble organic compound which is broken down in soil, mostly to inorganic arsenate bound as insoluble compounds which also exist naturally in the soil."

"Acute and chronic toxicity studies in a variety of animals indicates a low to medium toxicity rating. No teratological studies, nor toxicity studies in man seem to have been reported".

While co-authors and our committee have great respect for the National Academy of Sciences and their field work and research in South Vietnam its scope was limited. The NAS study (1971-1972) was conducted after President Nixon ordered the stop of herbicide spraying and completed just before he ordered in January, 1973 the withdraw of soldiers from the American Vietnam War. Furthermore, the study was conducted mostly from the air due to the un- 
stable political environment on the ground. This gave little chance for scientist boots on the ground. It is now time for a fresh look. Our findings and a re-assessment of the fate of Agent Blue, cacodylic acid, and arsenic including both water soluble and inorganic arsenate and arsenite makes this clear. In addition, there has been recent research [67] studying the effects of feeding chickens organic arsenic (non-toxic) supplements and their ability to convert it into inorganic arsenic (toxic Group-A carcinogen). As a result of these findings the use of organic rich chicken feed was banned in the United States. The feed had been used to make chickens more marketable (more plump, redder and prevent certain chicken diseases). Arsenic is a heavy metal and thought to be a carcinogen and dangerous.

\subsection{Disposal of Chemical Weapons Including Agent Blue (Davis-Monthan Air Base)}

Historically, most of the world's chemical weapons were disposed of at sea. This included the arsenic based chemical weapons [38]. The chemical weapon disposal sites were not well documented (Figure 29). Once dumped into the sea, the chemicals were leaked as a result of the corrosive action of seawater on steel barrels and containers. Davis-Monthan Air Force Base, near Tucson, Arizona is the home of the U.S. aircraft boneyard (Figure 30 and Figure 31) where retired military aircraft are stored. After President Nixon stopped the spraying the Rainbow herbicides including Agent Blue the excess stocks were removed from Vietnam by 1972. Most of the Rainbow herbicides containing dioxin (TCDD) herbicides were transported to Johnston Island in the Pacific Ocean for eventual incineration at sea [51]. Agent Blue, arsenic based, could not be burned due to its high concentrations of arsenic and was not a good candidate for disposal by

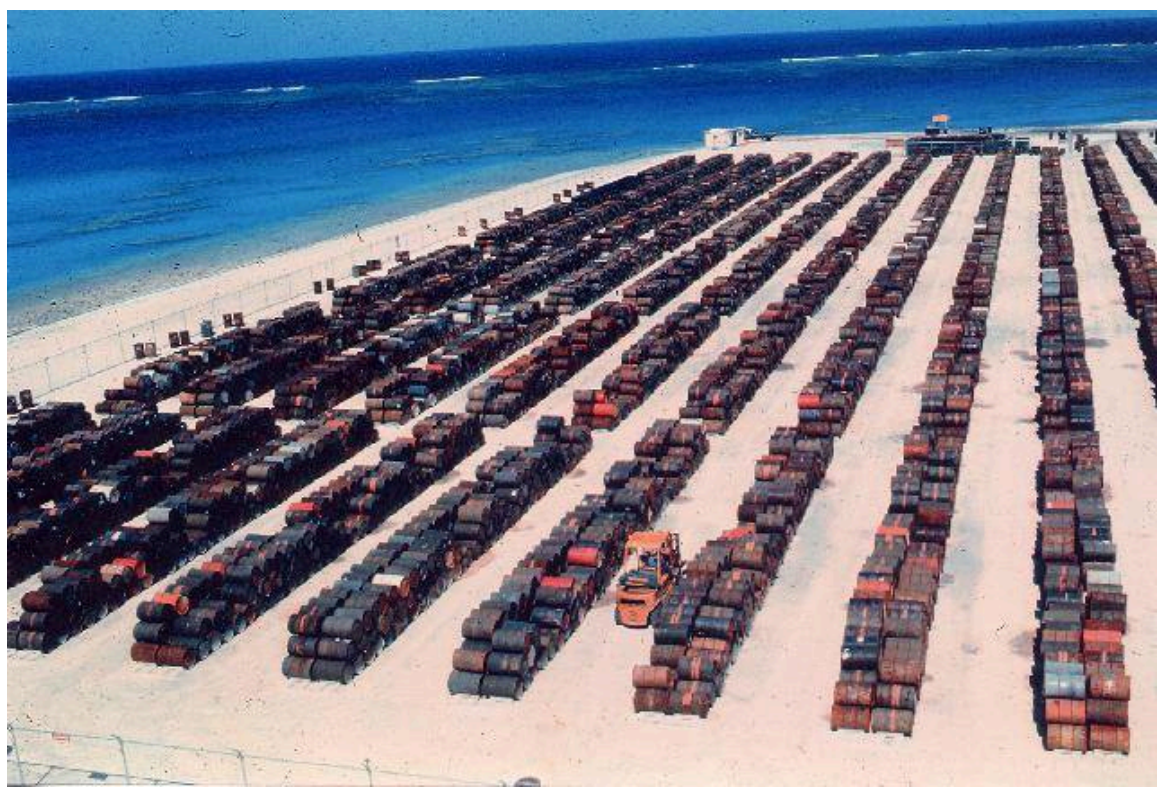

Figure 29. Rainbow herbicides being stored on Johnston Island in Pacific Ocean to be incinerated in 1977. 


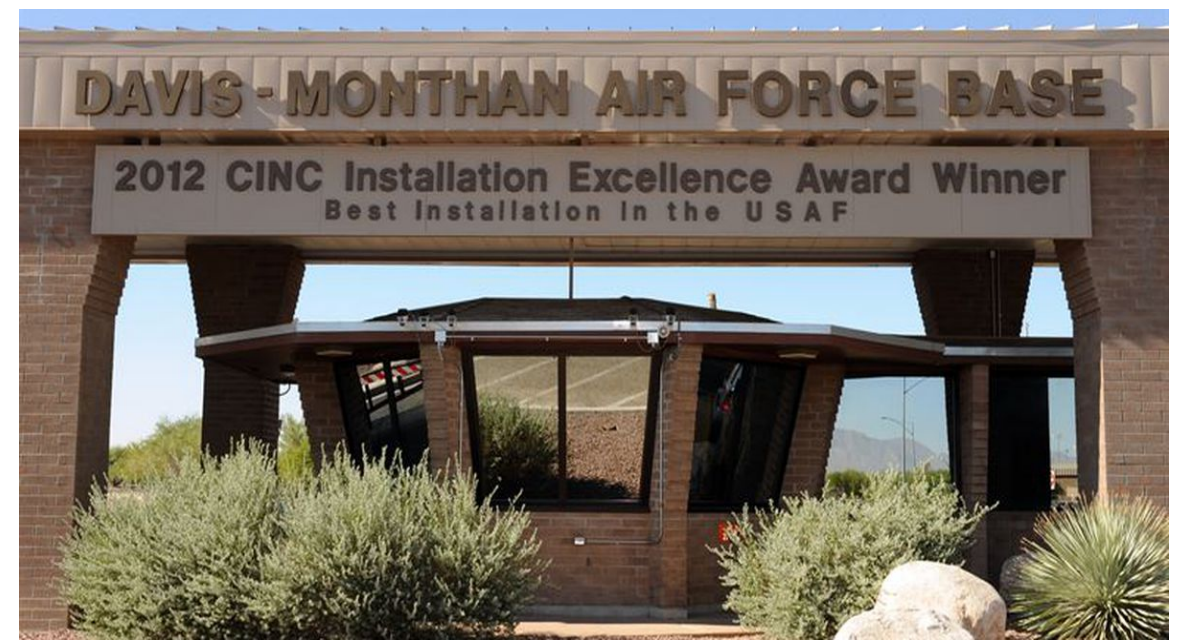

Figure 30. Davis-Monthan Air force Base Headquarters in Arizona. The final resting place for U.S. military planes.

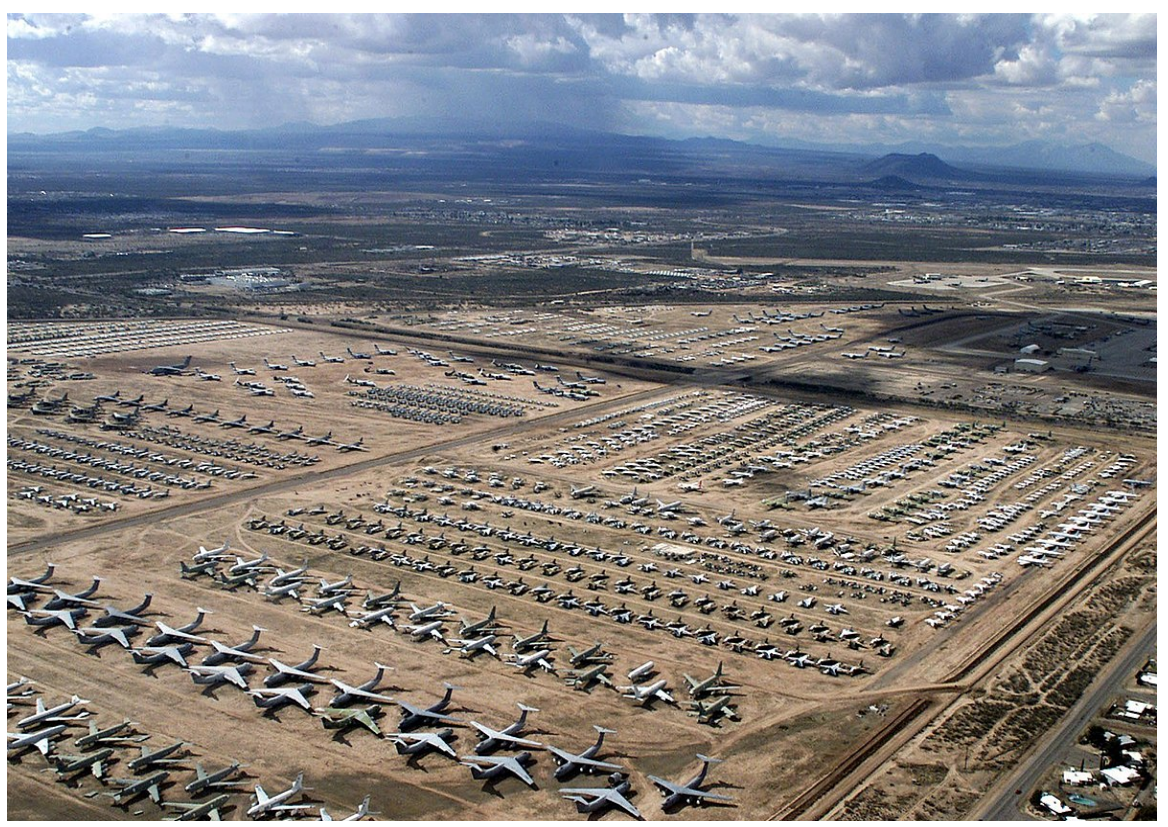

Figure 31. Perimeter fence at Davis-Monthan Air Force base in Arizona where the U.S. military planes go to die.

incineration at sea since arsenic can become arsine a toxic gas under reducing conditions. The Agent Blue stored in Vietnam and at Johnston Island was shipped to Davis-Monthan Air Force Base between 1972 and 1977. The grounds crew routinely sprayed Agent Blue along the perimeter fence and around the decommissioned airplanes (Figure 31) to keep the weeds down and to dispose of the remaining Agent Blue stockpiles.

\subsection{Source of Natural Arsenic in the Mekong Delta Surface Water, Parent Material and the Groundwater}

Both organic and inorganic arsenicals are naturally occurring minerals including 
arenopyrite (FeAsS), realgar $\left(\mathrm{As}_{4} \mathrm{~S}_{4}\right)$ and orpiment $\left(\mathrm{As}_{2} \mathrm{~S}_{3}\right)$ which were common in the Tibet Highlands. As these arsenic rich soils were eroded by runoff water and transported in the Mekong River they reacted with moisture and oxygen to form water soluble arsenites and arsenates. These arsenic compounds were transported by floodwaters onto the surface of the alluvial soils of the Mekong Delta and subsequently contaminated the surface and groundwater.

In surface waters the arsenites and arsenates can be absorbed by algae and converted to arsenites and arsenates and the algae converts these water soluble and inorganic arsenite and arsenate to arsenosugars, arsinolipids and arsenobetanine. Fish feed on the algae and concentrate the arsenic compounds. Due to relatively low toxicity of organic arsenicals there is little risk or concern about seafood [43]. However, rice grows in flooded paddies where surface water has four inorganic arsenicals that are absorbed by the growing rice plants which are translocated to the grain. The amount of arsenic that ends up in rice grain depends on how rich in arsenic the alluvium parent material and groundwater are. The Mekong Delta like most SE Asia Deltas has an abundance of natural arsenic in both the parent material and the groundwater.

Groundwater in Vietnam has naturally high arsenic due to arsenic-rich soils and geologic parent materials weathering and releasing arsenic into groundwater. Since the 1960s application of arsenic-laden herbicide (Agent Blue) during the Vietnam War, discharges from waste-water treatment plants and subsequent industrial developments as well as traditional Vietnamese burials, have all contributed dramatically to the levels of bio-available arsenicals in the soil and groundwater. During the last 20 years (2000 to 2019), the Vietnam government subsidized the proliferation of shallow tube-wells (Figure 3) and this ground water has become the primary source of drinking and irrigation water in the Mekong Delta [22]. This groundwater can have arsenic concentrations of up to $3050 \mathrm{ug} / \mathrm{L}$. Most of the arsenic is in the +3 and +5 oxidation states which is water soluble and the most readily available form for bio-accumulation.

\subsection{Effects of Arsenic in Rice Paddy Soil Systems}

Various researchers have studied the uptake of As and its fate in rice plants (Oryza sativa L.) grown on soils know to contain As [31] [32] [68] [69]. Juen et al. [70] observed that As uptake by rice plants may be variable with the highest accumulation of As found in the rice plant roots $\left(23.1 \pm 12.7 \mathrm{mg} \cdot \mathrm{kg}^{-1}\right)$ while grain concentration was much lower $\left(0.29 \pm 0.58 \mathrm{mg} \cdot \mathrm{kg}^{-1}\right)$ or about $1.2 \%$ of the root concentration. The ranking of As distribution in rice plants was root $>>$ stems $>>$ husk $>>$ grain. They suggest that rice roots along with an oxidized iron $(\mathrm{Fe})$ root plaque (often observed in wetland plants) provide an effective barrier to As translocation in the rice plant [70] [71]. This was supported by Lei et al. [72] who also reported that the Fe-containing root plaque and roots formed a barrier of As transport to rice grain. However, in their study on As contaminated soils, the levels of As in the grain were $245 \%$ higher than the limits suggested by 
local hygienic standards for grain.

\subsection{Lawsuits Involving Ansul Chemical Company and 10 Other Chemical Companies and Consent Orders: The 1979-1984 Vietnam Veterans versus Eleven Chemical Companies}

On January 8, 1979 Victor J. Yannacone, filed a class action suit, in re Agent Orange Product Liability Litigation (1979-1984) on behalf of all the Vietnam veterans that were exposed to Agent Orange containing dioxin and other Rainbow herbicides. By the end of the year, Yannaconee and associates represented 8300 Vietnam veteran clients in a law suit against 11 chemical companies including: Dow Chemical, Thompson-Hayward, Diamond Shamrock, Hercules Inc., Monsanto, Ansul Company (the manufacturer of Agent Blue), Riverdale Chemical Company, Uniroyal, Occidental Petroleum, Hooker Chemical Company and N.A. Phillips [28].

The chemical companies argued in federal court that the U.S. government was responsible for the injuries claimed by the veterans and their families. In addition, the companies argued that the government controlled the manufacturing, distribution and application of Agent Orange (and other Rainbow Herbicides including Agent Blue), some of which included dioxin (TCDD) although military contracts were thought to protect the Chemical companies. The U.S. Government having sovereign immunity, was eventually dismissed from the case. In May 1984, the Vietnam War Veterans and chemical manufactures settled out-of-court for $\$ 180$ million. These chemical companies could then renounce liability even though they knew about the toxic effects of by-product dioxin (or TCDD). However, the effects of arsenic were not addressed or were combined with dioxin TCDD. The fact that raising the heating temperature during the manufacture of Agent Orange to accelerate chemical reactions during the manufacturing process increased the dioxin levels up to 3000 times to magnify the toxicity of Agent Orange [28]. Although the manufacturing process for Agent Blue was different, this did not affect the inherent toxicity of As by itself. Many of the 52,000 Vietnam Veterans were dissatisfied with the amount of the settlement ( $\$ 3800 /$ veteran or the family). The judge ruled the out-of-court settlement was fair. The funds were dispensed by 1997. After the settlement the U.S. Government established an Endocrine Disruptor Screening Program to test industrial and agricultural chemicals for endocrine effects prior to marketing and use. The goal was to prevent future unanticipated consequences of the use of a new chemical or herbicide.

The Agent Orange Product Liability Litigation (1979-1984) records retained by the New Jersey State Council, Vietnam Veterans of America, Inc. were transferred in 1000 legal boxes to the Vietnam Center and Archive (VNCA) at Texas Tech University (personal communication from Executive Director Stephen Maxner) and are of immense importance to furthering our understanding of how Rainbow Herbicides with dioxin (TCDD) and Agent Blue with arsenic were manufactured and deployed during the Vietnam War. This specific collection is 
unique as it represents the years of document and material collection in preparation for the landmark "Agent Orange" legal action with regard to its contamination with dioxin and could include information and records about other Rainbow herbicides including Agent Blue. The resulting out-of-court settlement was of crucial importance in providing countless Vietnam veterans exposed to dioxin and perhaps arsenic and their families with much needed financial support and restitution. The settlement also resulted in the temporary storage of nearly 1,000 boxes of materials that provide detailed information regarding the eleven chemical manufacturers involved in Rainbow herbicide production and included Ansul Chemical Company which manufactured Agent Blue. These documents are the most comprehensive collection of military and government historical documents detailing the use and storage of Agent Orange and other potentially dioxin contaminated Rainbow herbicide defoliants and/or arsenic based herbicide (Agent Blue) throughout the entire Vietnam War. The Vietnam Center and Sam Johnson Archive submitted proposals in 2019 and 2020 (to National Academy of Humanities) to electronically scan the hundreds of thousands of documents. The collection will undoubtedly provide additional details pertinent to ongoing environmental and human health studies of Rainbow herbicide remediation programs in Vietnam, Thailand, Korea and the United States including various storage facilities on wartime military bases as well as U.S. chemical manufacturing sites, such as Newark, New Jersey; Marinette, Wisconsin; and Menominee, Michigan.

Ansul and other chemical companies were named as defendants in a 2005 lawsuit alleging that the use of the Rainbow herbicides by the U.S. military lead to serious birth defects for Vietnamese children and perhaps the U.S. military Vietnam veterans' children. The United States District Court for the Eastern District of New York ruled that the eleven defending companies were manufacturing Rainbow herbicides under the direct order of the Presidents of the United States and could not be sued for the consequences of the use of their herbicide products. The court also ruled that the British had previously used Agent Orange (with the by-product dioxin TCDD) during the 1950s Malayan Emergency and that they set the precedent for America's use in the Vietnam War.

\subsection{Impact of Agent Blue on Rice}

A poem written by Teresa Mei Chuc [73] immortalized the impact of Agent Blue.

Blue on rice paddies in the 1960s.

To kill correctly takes calculation.

Down to a science arsenic cacodylic acid.

Knows water and rice on a cellular level.

Make sure no surviving seed can be collected and planted.

Because even a small seed assures survival.

Because mortars, grenades and bombs cannot destroy a grain. 
Because our heart is made of seeds.

Know what it takes to kill the seeds.

Know what it takes to deprive the plant of water, to dehydrate it.

To be surrounded by love but unable to absorb it.

\section{Findings}

The arsenic-laden Agent Blue herbicide was used to kill rice food crops and bamboo during the Vietnam War. Spraying Agent Blue added a significant amount of water soluble arsenic to the rice roots, rice grains, water and soil. The United States and Republic of Vietnam militaries sprayed and dumped Agent Blue on the rice paddies to desiccate rice plants and then burn the rice residue and seeds. As a result, toxic As-containing aerosols and smoke were released to the atmosphere.

The subsequent industrial development and waste water treatment plants have resulted in dangerously spiked bio-available arsenicals in the surface and groundwater of the Mekong Delta. During the last two decades, thousands of government-subsidized shallow tube wells have been built. Shallow groundwater has become the major source for irrigation and drinking water rich in arsenic in Vietnam. Groundwater in concentrations has been measured as high as 3050 $\mathrm{ug} / \mathrm{L}$. The potential sources of arsenic in the hotspots were examined.

\subsection{Potential Impact of the Burial of Millions of Vietnamese in the Mekong Delta from the Vietnam War in 1960s to Present on the Arsenic Levels in the Groundwater}

Since the 1940's millions of Republic of Vietnam military soldiers and Vietnamese civilians have died and been interned in South Vietnam including the Mekong Delta and Central Highlands [74]. Before and during the American Vietnam War (1962-1971) the Republic of Vietnam military and Vietnamese civilians were exposed to Agent Blue which was applied (7.8 million liters with $1,232,400 \mathrm{~kg}$ of As) to approximately 300,000 ha of rice paddies and to the 100,000 ha Mangrove forests and all the military base perimeter fences in South Vietnam. During the American Vietnam War (1965-1972) thousands of Republic of Vietnam military and Vietnamese were killed and buried in the Mekong Delta or other parts of South Vietnam (Figure 31).

The rice paddy farmers and adjacent villages came in contact with Agent Blue primarily through skin contact, breathing the arsenic and ash after the burning of the rice fields, and from living in the adjacent local villages in both the Mekong Delta and the Central Highlands [54] [55]. In addition, at this time, the waterways, gardens, animals and nut crops were contaminated with As from Agent Blue spraying. The rice, shrimp, animals and fish exposed to Agent Blue resulted in arsenic being bioaccumulated in humans after being eaten by the local Vietnamese. The U.S. military personnel which had their own water and food supplies did not routinely ingest the As contaminated food but the treated drinking water only had the sediment filtered out and chlorine added to kill the 
organisms. A water soluble arsenite or arsenate would remain in the water. The dioxin TCDD would probably be attached to the sediment and removed during filtration. However, the U.S. military with boots on the ground may have been exposed to As-containing aerosols, smoke and ash from the burning rice plants. In addition, the water soluble arsenite $(+3)$ and arsenate $(+5)$ leached into the groundwater and contaminated the drinking water for the millions of Vietnamese living on the Mekong Delta from the 1960s to present.

Agent Blue deposited in the rice paddy water moved into the plant root zone, and could be taken up by rice plants in subsequent years or leached through the saturated soil into the groundwater and re-pumped to the surface. In later years (after 1975), the rice plants continued to take up the arsenic from As rich paddy water and stored it in the plant tissue and trace amounts in the grain. The rice grain, tainted with trace amounts of inorganic arsenic, was either eaten by the Vietnamese or sold on the national and international markets.

The manufactured arsenic in Agent Blue became mixed in the rice paddy root zone and shallow groundwater with the naturally occurring arsenic in the underlying sediments and groundwater which were transported thousands of kilometers in solution via the Mekong River from the Tibet Highlands. The sediment was deposited on the alluvial soils and the water soluble arsenite and arsenate in the floodwaters covered the alluvial soils and eventually was ponded and leached into the groundwater of the Mekong River and into the South China Sea.

Can anthropic arsenic be separated from natural arsenic? At this time there does not appear to be a method, including isotope identification methods, to separate manufactured arsenic from natural arsenic in solution [44]. The only way to potentially accomplish this is to locate a natural area that has not been subjected to impacts by human activity prior to the Vietnam War to determine natural soil As levels. This is highly unlikely because nearly every place on earth, including deltas, has been directly or indirectly impacted by human activity. What we do know is that arsenic will continue to exist in the Mekong Delta. However, trace amounts can volatilize, small amounts retained by the soil, or be removed from the rice paddy by flooding, surface drainage or leaching into the groundwater. Decomposing rice plant residues can also recycle arsenic within the root zone.

The Vietnamese who were exposed by skin contact with Agent Blue from 1961 to 1971 most likely had elevated levels of arsenic which would have bioaccumulated in their bodies. The next generations of Vietnamese, from 1972 to present, could have ingested low levels arsenic from the food supply, mostly fish and rice, and drinking water. The buried Vietnamese bodies would also have elevated arsenic levels, as a result of bioaccumulation, if they died between the end of the Vietnam War (1975) and the 2020s. Most deceased Vietnamese would have been interned in coffins below ground in Mekong Delta (Figures 32-34). Researchers could calculate the amount of arsenic contributed to the soil and ground water during the last 55 years by the burial of millions of Vietnamese in 


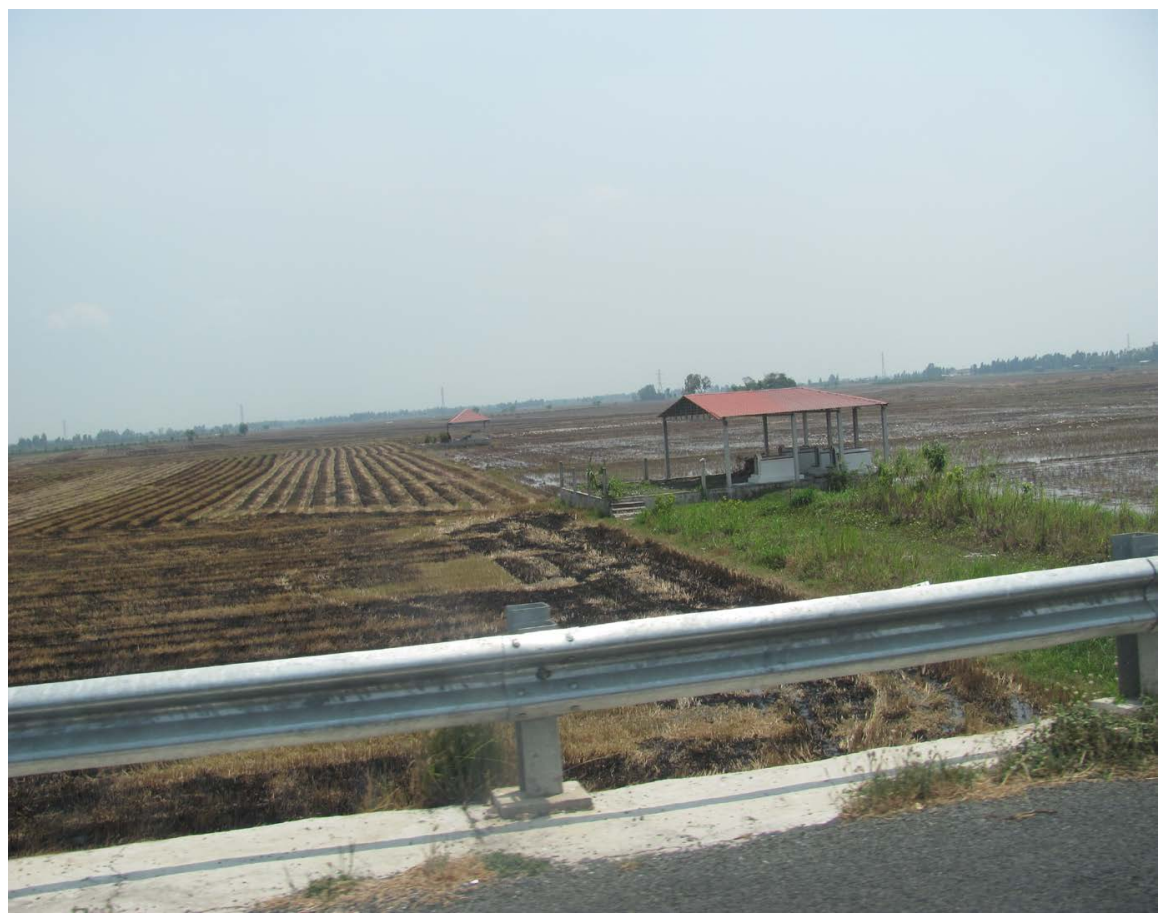

Figure 32. Cemeteries in rural rice fields of the Mekong Delta in Vietnam.

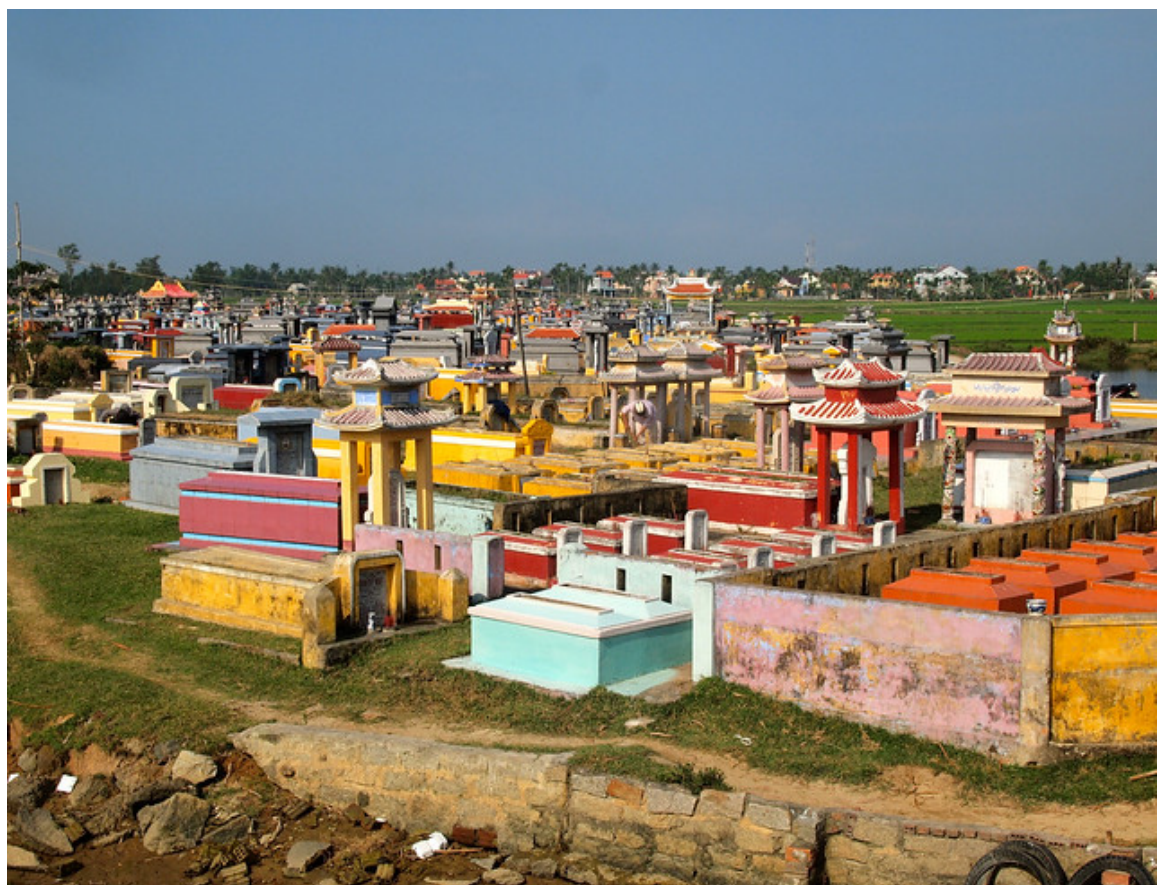

Figure 33. Urban cemetery in the Mekong Delta of Vietnam.

the Mekong Delta to assess the magnitude of the problem and determine whether or not it is the cause of the some arsenic spikes and which could potentially contribute to the water soluble arsenic entering groundwater and the food supply (rice) of the people still living on the Mekong Delta.

There are proven methods to mitigate high levels of arsenic in groundwater 


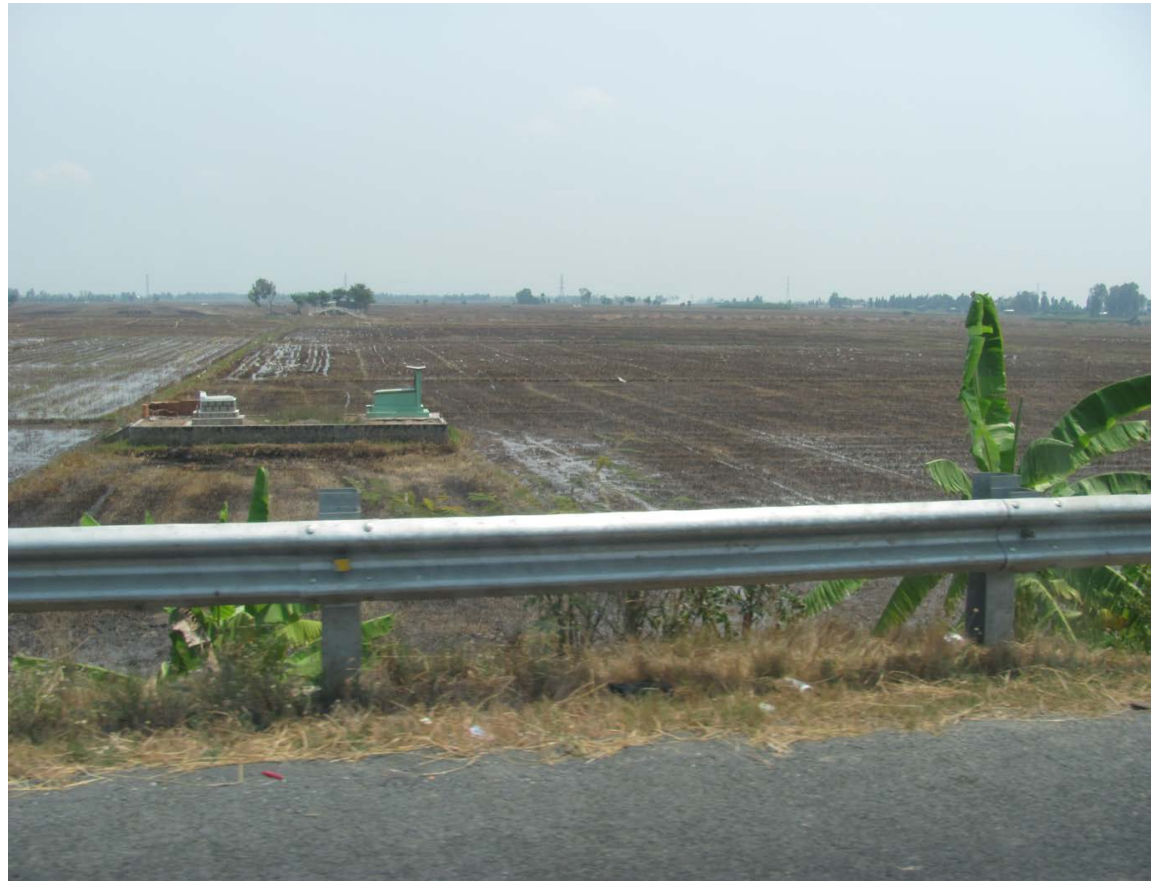

Figure 34. Rural cemeteries in rice fields of Mekong Delta in Vietnam.

regardless of the historic or natural sources. This drinking water treatment needs to happen. These methods are noted in the mitigation section (Section 3.4 of this paper). The long-established traditional Vietnamese ethnic group burial practices [75] can continue if steps are taken to reduce As levels in the Mekong Delta drinking and irrigation water. However, this burial topic could become a cultural taboo in Vietnam. Vietnam policy-makers need to consider the ethnic group cultural and burial practices as they try to deal with As contamination in the groundwater using mitigation and technical measures to reduce the arsenic levels in the Mekong Delta.

\subsection{Agent Blue Impact on Human Health}

Over the years the Veterans Administration (VA) has received Vietnam veteran benefit claims as a result of exposure to dioxin TCDD [76] which is in all the Rainbow herbicides except Agent Blue. In some cases, Vietnam veterans also claimed benefit as a result of exposure to Agent Blue the arsenic based rice killer. Both Agent Blue and Agent Orange were sprayed on the Vietnam and Thailand military base perimeter fences as part of an attempt to kill the jungle vegetation to enhance base security. It was not always possible to determine which Rainbow herbicide (Figure 35) caused a specific disease in U.S. and Republic of Vietnam veterans who were exposed to both dioxin TCDD and arsenic. Most U.S. Vietnam veterans were not even aware of the presence of Agent Blue even though 7.8 million liters $(1,232,400 \mathrm{~kg}$ of As) were applied to 300,000 ha of rice paddies, 100,000 ha of forest and some U.S. military base perimeter bases in South Vietnam and Thailand. 


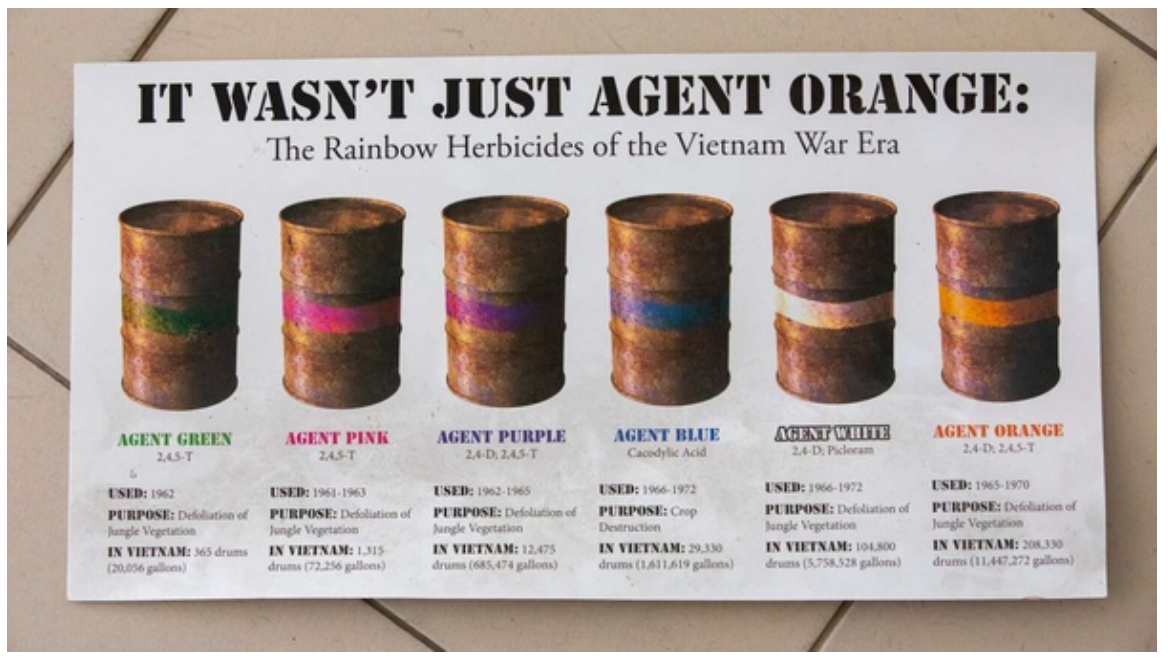

Figure 35. Rainbow herbicides identified in a chart with appropriate color striped barrels.

\subsection{Vietnamese Exposure to Arsenic from Agent Blue Applications during Vietnam War}

There were millions of Vietnamese living in the Mekong Delta during the Vietnam War and who were directly affected by exposure to Agent Blue spray and then had to breathe smoke which included inhalable volatile As aerosols and ash from the burning of dried out rice plants. Arsenic has no half-life and continues to exist in the rice paddy environment to which it was originally applied. Arsenic can volatize, be taken up by the rice plant and trace amounts of arsenic are removed in the rice grain. As-containing rich rice plant residues (which is higher in As than the grain) were returned to the soil. Some water soluble arsenite and arsenate leached into the groundwater.

\subsection{Mitigation of Agent Blue and Naturally Occurring Arsenic Which Continues to Persist in Vietnam Food Supply and Water}

The legacy effects of natural and anthropic As in South Vietnam soils, rivers and canal systems pose urgent food security and health risks from persistent contamination in agricultural soils and water used for crop irrigation and human consumption. The residue of widespread and repeated use of arsenic-based herbicides can result in phyotoxicity in crops depending on the plant species, soil type, and prolonged exposure to As contaminated water [29] [31]. Mitigation strategies involve addressing water management, fertilization decisions, and crop selection and specific cultivars.

Management of As contaminated water can reduce concentration of As in food supplies. Recent experiments show rice grain crops grown in soil with high As concentrations had elevated levels of As in the rice roots, leaves, grain, cooked rice, hulls, and straw [32] [77] [78]. The flooded or wet rice production system traditionally transplants seedlings into puddled paddy fields. In this planting system, anaerobic As contaminated soil promotes increased As availability and 
uptake by the plant resulting in high As concentration in rice straw and grain [31] [32]. Many of Vietnam's Delta soils are high in iron oxides. Under anaerobic conditions such as flooded rice paddies, iron oxides are reduced and release inorganic As from sediments and soils making the As more available for plant use. Water management experiments show that growing rice in irrigated furrows and raised beds rather than flooding the entire field reduces As concentrations in rice primarily because under aerobic conditions As is bound to iron oxides and not available for plant uptake [32]. This alternating wet and dry irrigation reduces the amount of As deposited in the soil from soluble As in the irrigation waters and lowers the As bioaccumulation in plants [31].

Other mitigation strategies to reduce the arsenic loads in the food supply are selection of the rice cultivar and rotations with other non-rice crops with low As uptake [31] [78]. Screening of rice cultivars that do not easily uptake As and translocate into the grain reveals that root traits with higher porosity and capacity to form iron plaques that bind more As result in lower As concentration levels of translocation throughout the plant [77]. Other species that generate reactive oxygen and produce antioxidant enzymes have been found to reduce As toxicity and enhance plant resistance to bioaccumulation [78]. Much more research in this area is needed to identify and test crops and specific cultivars with high As resistance.

In some instances, certain plant species have the ability to be utilized to phytoremediate As contaminated soils and water. Examples of such plant species are ribworth plantain (Plantagolancelota L., Holcuslanatus), mosses, lichens, tamarisk (Tamarixparviflora), Eucalyptus (Eucalyptus camaldulensis), Chinese Brake fern (Pterisvittata L.) and species within the genus Arundo [80]. However, accumulator plants must then be harvested and removed; then reduced by composting, digestion, or ashed. The resulting ash or residue must then be disposed of in a manner that does not create further environmental problems.

Fertilizer choices and soil amendments to rice and vegetable crops can affect As levels above health and safety standards. Arsenic uptake and translocation throughout a plant varies with the crop: some Brassicaceae have high As uptake potential while others have lower As uptake such as carrots, lettuce, bean, and tomatoes respectively [78]. Adequate levels of silicon and sulfur can increase the resistance to uptake mechanisms in rice and some types of vegetables [77] [78] while phosphate-based (P) fertilizers increase plant As extraction from the soil and plant availability. P levels in soils have significant effects on rice yields, thus complicating the farmer's decision to use the recommended $\mathrm{P}$ applications to obtain higher yields while risking an increase in As uptake. Rice production experiments using boro rice cultivar grown in aerobic conditions (raised bed with irrigated furrow) and $100 \%$ of the recommended $\mathrm{P}$ found yields were $12 \%$ higher than in flooded rice management; and had lower total As concentration compared to the flooded rice management system [33]. Phosphate and arsenate are chemical equivalents, both competing at sorption sites [78]. Further they note 
that phosphate can desorb arsenate from $\mathrm{Fe}, \mathrm{Al}$ and $\mathrm{Mn}$ oxide surfaces increasing As mobility and availability for crop uptake. Iron (Fe) with elemental sulfur (S) has substantial charge and surface area to bind As (III) and As (V) and reduce soil bioavailability.

U.S. agricultural lands, where arsenic-based pesticides were routinely used for decades, continue to have levels of As in the soil that exceeds safety standards [78]. Experiments growing vegetable crops on these contaminated soils find that the soil threshold of As concentration varies greatly by crop. Tomatoes have a high resistance to As uptake and are thought to be safely grown at As $>300$ $\mathrm{mg} \cdot \mathrm{kg}^{-1}$; in contrast carrots $\left(<100 \mathrm{mg} \cdot \mathrm{kg}^{-1}\right)$ and lettuce $\left(50 \mathrm{mg} \cdot \mathrm{kg}^{-1}\right.$ have a much higher propensity to uptake As and far lower safety levels [79]. Researcher's cautioned that soils with As above $300 \mathrm{ppm}$ can be harmful to humans from direct skin contact and hand-to-mouth exposure to soil particles that are attached to harvested root and leafy greens crop. While soils and climate conditions differ, these experiments suggest Agent Blue uses in the 1960s and persistence in the environment are likely to have differing long term impacts on Vietnam cropping systems.

The magnitude of naturally occurring As and the historical legacy of arsenic contamination of soil and water in Vietnam deltas places today's population at huge risk of chronic arsenic poisoning. It is urgent that investment in As mitigation research on food production systems, irrigation water and drinking water contamination be accelerated; and policies put in place to provide technical and financial support to farmers and community leaders seeking to address this complex and pervasive health concern.

\section{Discussion}

The quotes in Section 2.22 of the National Academy of Sciences: Part A Summary and Conclusions report [44] suggests that the fate of Agent Blue, the cacodylic acid the active component in Agent Blue, and the water soluble arsenite and arsenate $(+3$ and +5$)$ was assumed to be tightly bound to the soil compounds in the root zone. However this was not always the case. In this paper we explain that the arsenic exists in 4 forms including two water soluble forms arsenite $(+3)$ and arsenate $(+5)$, which is a water soluble arsenic salt, and much of the water soluble arsenic is actually leached from the rice paddy and root zone into the Mekong Delta or Central Highland groundwater potentially contaminating shallow groundwater.

More recent toxicology studies have shown that the arsenic in drinking water and the food supply can and does bioaccumulate in humans. Other studies have shown that the organic arsenic can be ingested by chickens and become inorganic arsenic a hazardous carcinogen. The supplying of organic arsenic rich feed to chickens is now banned in the United States.

It is now well known that arsenic does not have a half-life and once introduced into the South Vietnam environment it continued to exist. The Mekong 
Delta and Central Highlands drinking water and the food supply, including rice, shrimp and fish, contain trace amounts of arsenic which can be bioaccumulated over decades. The 1974 NAS report [44] was only a 2-year study with most of the focus on Agent Orange dioxin TCDD and the Mangrove forest damage. An environmental study of the impact of Agent Blue, the arsenic based rice killing herbicide, on the environment, animals and humans are now long overdue.

It does appear that the U.S. military veterans were less exposed to arsenic than the Vietnamese civilians since they did not normally drink the contaminated local water without an attempt to filter to remove the contaminated soil particulate matter, and then chlorinated the water to kill the pathogens. However, there was apparently no attempt to remove the pesticide contaminants such as arsenite, arsenate, and dioxin TCDD. If present the dioxin TCDD would probably have been removed with the filtered sediment or particulate matter. The Republic of Vietnam military and Vietnamese civilians did drink the untreated local surface and groundwater and the civilians have continued to drink the treated and untreated water and food with trace amounts of arsenic for the last 50 years.

The U.S. military veterans had limited exposure, usually one year, to Agent Blue, cacodylic acid, arsenic, and dioxin TCDD and had a much lower risk of bioaccumulating arsenic. However, some U.S. Vietnam veterans were exposed directly to Agent Blue, cacodylic acid and arsenic during the handling of the Agent Blue barrels and the transport and distribution process as well as from the spraying on the rice paddies, mangrove forests and the perimeter military base fences. It is not clear to this day if the VA medical doctors treating the Vietnam veterans for the last 50 years knew much about Agent Blue, the arsenic based herbicide. Evidence suggests they probably did not and they apparently made no attempt to measure the arsenic levels in the Vietnam veterans since dioxin TCDD was their focus. Rather than determining whether any of the health issues were linked to Agent Blue and arsenic the medical doctors apparently lumped Agent Blue exposed veterans in with the other veterans exposed to Agent Orange, Agent Pink, Agent Purple and Agent White which contained dioxin TCDD but not arsenic. Agent Orange plus Agent Purple, Agent Green, Agent Pink and Agent White were applied more widely and frequently than Agent Blue by a factor of 10 or 20 based on all Rainbow herbicide shipment records. Therefore, Agent Blue, the arsenic based herbicide, was less of a medical concern and not everyone was aware that Agent Blue did not contain dioxin TCDD. If the Agent Blue military handlers, spraying Agent Blue on rice paddies, Mangrove forests and military base perimeter fences, were exposed to arsenic they might have been grouped with the Agent Orange dioxin TCDD exposed U.S. military veterans working in Operation Ranch Hand. There is little information available to assess the exposure of the military veterans to Agent Blue, cacodylic acid and arsenic.

Even when DOD funded the clean-up in 2018 of the dioxin TCDD hotspots in Vietnam, such as Bien Hoa airbase where three thousand soil samples were collected, these samples were not checked for arsenic. Arsenic levels in the soil was 
not the focus of the clean-up effort due to cost of analysis and the focus on Agent Orange dioxin TCDD. Therefore no arsenic data was provided in the 870 page USAID report [80] which summarized the Hatfield field sampling and their research report. There is still a need to determine if arsenic levels in Central Highlands and the Mekong Delta are still adversely affecting Vietnamese civilian health after more than 50 years. There is a growing set of water quality data that shows significant spikes in arsenic levels at specific locations in the Mekong Delta and in the Red River Valley (Hanoi) which was not sprayed with Agent Blue during the Vietnam War so the cause or causes remain unknown in most cases.

\section{Summary and Conclusions}

The U.S. military use of the arsenic-based herbicide, Agent Blue and the subsequent food destruction program in South Vietnam was not a secret but only received scant publicity [80] during the Vietnam War. The same is true to this day. Post-war, the authoritative study by the National Academy of Science (44) on the Rainbow herbicides and their use in South Vietnam had little scientific information about Agent Blue and the soil-chemical processes of natural and anthropic arsenic, and seriously underestimated short- and long-term persistence of As in soil, sediments, and water. They assumed, without teratological studies or toxicity studies in humans, that because As was naturally occurring in the soil, it was not harmful to animals or humans.

We know otherwise today. "Arsenic in groundwater poses a massive and growing human health threat" throughout Southeast Asia, especially the Mekong and Red River Deltas of Vietnam [30]. Human exposure by way of inhalation (airborne arsenic) contaminated drinking water, and food supplies grown in As contaminated soil and water can result in acute arsenical poisoning with carcinogenic and genotoxic potential [67].

The use of Agent Blue, the arsenic based herbicide manufactured by Ansul Company and its use during the Vietnam War years requires a careful historical analysis to understand the impacts of arsenic on soil, sediment and water resources and the potential legacy effects today. The Republic of Vietnam and U.S. militaries began destroying food crops in South Vietnam in November of 1962 as part of their "resource denial" program. This was primarily an aerial application of Agent Blue applied at a rate of $10.5 \mathrm{~kg} / \mathrm{ha}$. Agent Blue was highly hazardous chemical herbicide that was not registered for use on U.S. crops [81]. Westing [81] suggested that most of the destruction occurred in Central Highlands of South Vietnam which is north of Saigon and the Mekong Delta which is south of Saigon. This region was traditionally food poor and the population consisted of Hill tribes (Montagnards). Spraying of the upland rice was carried out just before harvest time, destroying the standing crop and rendering the land useless for at least one year.

The program objective was to cut off the food supply to the approximately 
260,000 Democratic Republic communist insurgents in South Vietnam with a population of 17.5 million Vietnamese. The insurgents were only 1.5 percent of the population but the destruction program required cutting off food supply for the insurgents and civilian South Vietnam population. The average Vietnamese could subsist on $180 \mathrm{~kg}$ of milled rice per year and the upland rice could produce $230 \mathrm{~kg}$ of milled rice per hectare per year [81]. The insurgent only required 46.8 million $\mathrm{kg}$ of milled rice compared to the 3.15 billion $\mathrm{kg}$ of milled rice needed to feed the Vietnamese civilian population. A hectare of upland rice could produce $230 \mathrm{~kg}$ of milled rice year so to deny the insurgents their access to their food supply required the destruction of 13.7 million hectares (a land area the size of Iowa) of rice [78].

Agent Blue was the only Rainbow Agent (Figure 35) or herbicide primarily used to target food crops. Agent Blue was used on grasses and narrow-leaved plants such as bamboo and rice. The rice paddies could not be destroyed by burning (when they were green and growing) or drained by blowing up dikes and borders. Agent Blue desiccated rice plants before crop maturity and allowed burning to kill the seeds and clear away potential cover for enemy combatants. The U.S. and Republic of Vietnam military strategy were to attack the South Vietnamese food supply and force the South Vietnamese to abandon their rice paddies and move into strategic hamlets or the urban slums of Saigon. The rural villages could then no longer provide support, food and protection for the communist insurgents. Even if most of the rice was grown for family consumption the insurgents would either be given rice or it could be taken from the villagers. It is estimated that 1.5 million Vietnamese were uprooted and eventually migrated to urban slums in South Vietnam including Saigon as a result of being victims of Agent Blue spraying and a reduced food supply.

The fate of arsenical herbicides in the saturated soil environment includes: 1) reacting with and being retained by the compounds in the soil, 2) volatilized into the atmosphere from biological transformations and burning, 3) leached out through the saturated soil and into groundwater, and 4) taken up by plants from groundwater and accumulated on the topsoil [34].

The U.S. and Republic of Vietnam military personnel and Vietnamese villagers were told that the sprays were safe and C-47 aircraft would drop leaflets just before or after spraying. The leaflets explained that the herbicides were harmless and spraying was to keep the villagers safe from the communist insurgents. Small planes would also fly over villages broadcasting tape-recorded messages in Vietnamese to help re-assure villagers that the herbicide spray was not harmful.

Arsenic levels are naturally high in the Mekong Delta environment of Vietnam. The human exposure to arsenic is primarily (99\%) through ingestion of drinking water and food after 1975. Prior to 1975 and during the Vietnam War arsenic was accumulated in the Vietnamese from skin contact with Agent Blue contaminated and inhaled arsenic laden smoke from the burning of the dried-out rice plants and seeds. Arsenic is known as the "king of poisons" and is 
mutagenic, carcinogenic, and teratogenic.

The introduction of Agent Blue to South Vietnam occurred in 1961 and Agent Orange and other Rainbow herbicides were introduced in 1965. The Vietnam War represented an application of a new technique for modern herbicide and chemical warfare [82]. Scientists and some politicians thought that the U.S. Military was introducing chemical warfare in opposition to previous international agreements and the herbicides were actually chemical weapons and in violation of the Geneva Convention. This is probably part of the reason that USAID provided \$30 million to humanitarian relief to the Vietnamese (primarily for exposure to dioxin TCDD) in 2018 and the Department of Defense contributed another \$330 million in 2019 help clean-up the environmental problems, Bien Hoa Air Force base, including dioxin TCDD that the U.S. Military left behind in South Vietnam 50 years ago.

According to Institute of Medicine, over 7.8 million liters $(1,232,400 \mathrm{~kg})$ of Agent Blue were sprayed on crops between 1961 and 1971 and the effects of Agent Blue based arsenic were understated. Spray drift impacted many hectares adjacent to the targeted rice paddies including local villages. Crops were sprayed and then burned after desiccation and actually released arsenic laden smoke which polluted the South Vietnam air. The Republic of Vietnam and United States military personnel also had to breathe the arsenic laden smoke from 1961 to 1971 . The smoke was also spread by wind and water transport to adjacent land and to rivers and bodies of water. Today, Vietnamese rice for domestic and export is still tainted with trace amounts of arsenic from anthropic and natural groundwater sources.

New scientific understanding of As in soil, sediments and water provide critical insights and important guidance in the development of mitigation strategies. New technologies, experiments in cropping systems, changes in fertilizer management and increased collaborative sharing and transfer of information and knowledge are needed to reduce and eliminate arsenic from Vietnam drinking water and food supplies. Further, local monitoring of water and soil conditions, water management planning, policies and financing mechanisms are needed to assist farmers, local and district leaders, and communities to adopt proven new practices.

Further Vietnam investigation is needed to: 1) evaluate the historical and current extent of soil contamination with As, 2) evaluate the historical and current extent of water contamination with anthropic and natural As; and 3) evaluate current levels of food contamination with As (especially rice, fish and shrimp) in the areas where Agent Blue was used. This would provide a much clearer picture of the long-lasting effects of indiscriminate heavy use of an As herbicide on food crops, the human food chain and bioaccumulated in humans.

\section{Acknowledgements}

The research study and publication were published with support and approval of the Merry Band of Retirees committee which include nine U.S. Army and Viet- 
nam Era veteran members and four Agricultural College Professors. The co-authors appreciate the Vietnam Center and Sam Johnson Archive willingness to archive this Agent Blue article and make it available to future Vietnam War historians.

\section{Conflicts of Interest}

The authors declare no conflicts of interest regarding the publication of this paper.

\section{References}

[1] Uthus, E.O. (1992) Evidence for Arsenic Essentiality. Environmental Geochemistry and Health, 14, 55-58. https://doi.org/10.1007/BF01783629

[2] Olson, K.R. and Miller, G. (2020) St. Lawrence Seaway: Western Great Lakes Basin. Journal of Water Resource and Protection, 12, 637-656. https://doi.org/10.4236/jwarp.2020.128039

[3] Department of Army (1971) Field Manual: Tactical Employment of Herbicides. Washington DC.

[4] Young, A.L. and. Gegigani, G.M. (1988) Agent Orange and Its Associated Dioxin: Assessment of a Controversy. Chapter 2. Military Use of Herbicides Were Applied by United States in a Tactical Operation Designed to Reduce Ambushes and Disrupt Enemy Tactics. Elsevier Publishers, New York, Amsterdam.

[5] Morton, L.W. and Olson, K.R. (2018) The Pulses of the Mekong River Basin: Rivers and the Livelihoods of Farmers and Fishers: Sustainable Agriculture. Journal of Environmental Policy, 9, 431-459. https://doi.org/10.4236/jep.2018.94027

[6] Young, A. (1982) Development of an Exposure Index for an Epidemiologic Study of Ground Troops Exposed to Agent Orange during Vietnam War. Office of Environmental Medicine, Veterans Administration, Washington DC.

[7] Yan, X.L., Chen, T.B., Liao, X.Y., Huang, Z.C., Pan, J.R., Hu, T.D., Nie, C.J. and Xie, H. (2008) Arsenic Transformation and Volatilization during Incineration of the Hyperaccumulator Pteris vittata L. Environmental Science and Technology, 42, 1479-1484. https://doi.org/10.1021/es0717459

[8] Gupta, A. (2009) Geology and Landforms of the Mekong Basin. In: Campbell, I.C., Ed., The Mekong: Biophysical Environment of the International River Basin, Chapter 3, Elsevier, Amsterdam, 251-272. https://doi.org/10.1016/B978-0-12-374026-7.00003-6

[9] Olson, K.R. and Morton, L.W. (2017) Why Were the Soil Tunnels of Cu Chi and Iron Triangle in Vietnam So Resilient. Open Journal of Soil Science, 7, 34-51. https://doi.org/10.4236/ojss.2017.72003

[10] Olson, K.R. and Speidel, D.R. (2020) Review and Analysis: Successful Use of Soil Tunnels in Medieval and Modern Warfare and Smuggling Open Journal of Soil Science, 10, 194-215. https://doi.org/10.4236/ojss.2020.105010

[11] Clift, P.D., Carter, A., Campbell, I.H., Pringle, M., Nguyen, V., Allen, C., Allen, C.M., Hodges, K.V. and Mai, T.T. (2006) Thermo-Chronology of Mineral Grains in the Red and Mekong Rivers, Vietnam: Provenance and Exhumation Implications for Southeast Asia. Geochemistry Geophysics Geosystems, 7, 1-28. https://doi.org/10.1029/2006GC001336

[12] Mekong River Commission (2010) The First Mekong River Commission Summit 
2010. 4-5 April 2010.

[13] Carling, P.A. (2009) Geology of the Lower Mekong River. In: Campbell, I.C., Ed., The Mekong Biophysical Environment of an International River Basin, Elsevier, New York, 13-28. https://doi.org/10.1016/B978-0-12-374026-7.00002-4

[14] Dudal, R. and Moormann, F.R. (1964) Major Soils of South-East Asia. Journal of Tropical Geography, 18, 54-80.

[15] Moormann, R. (1961) The Soils of the Republic of Vietnam. Ministry of Agriculture, Saigon.

[16] Dudal, R., Moorman, F.R. and Riquier, J. (1974) Soils of Humid Topical Asia. UNESCO, Natural Resources of Humid Topical Asia. Natural Resource Research XII, 159-173.

[17] US Environmental Protection Agency (USEPA) (2016) National Wetland Condition Assessment 2011: A Collaborative Survey of the Nation's Wetlands. EPA 843 R 15 005.

https://www.epa.gov/sites/production/files/2016-05/documents/nwca 2011 public report 20160510.pdf

[18] Olson, K.R. and Morton, L.W. (2018) Polders, Dikes, Canals, Rice, and Aquaculture in the Mekong Delta. Journal of Soil and Water Conservation, 73, 83A-89A. https://doi.org/10.2489/jswc.73.4.83A

[19] Taylor, P. (2014) The Khmer Lands of Vietnam: Environment, Cosmology, and Sovereignty. ASAA Southeast Asia Publication Series, University Hawaii Press, Honolulu. https://doi.org/10.2307/j.ctv1nthxg

[20] Nayna, J., Nguyen, T.D. and Ngyyen, K.D. (2018) Mangrove Collaborative Management in Vietnam and Asia. USAID Collaboration. https://www.land-links.org/wp-content/uploads/2018/03/USAID Land Tenure T GCC Mangrove Collaborative Management Vietnam Asia.pdf

[21] Santasombat, Y. (2011) The River of Life Changing Ecosystems of the Mekong Region. Mekong Press, Chiang Mai.

[22] Islam, S., Rahman, M.M., Islam, M.R. and Naidu, R. (2016) Arsenic Accumulation in Rice: Consequences of Rice Genotypes and Management Practices to Reduce Human Health Risk. Environment International, 96, 139-155. https://doi.org/10.1016/j.envint.2016.09.006

[23] Tsuji, H. (1977) Rice Economy and Rice Policy in South Vietnam Up to 1974. East Asian Studies, 15, 264.

[24] Helgi Analytics (2020) Rice Consumption per Capita in Vietnam. Helgi Library, Prague.

https://www.helgilibrary.com/indicators/rice-consumption-per-capita/vietnam/\#: : text=Historically\%2C\%20rice $\% 20$ consumption $\% 20$ per\%20capita\%20in $\% 20$ Vietna m\%20reached,Laos\%20and\%20178\%20kg\%20in\%20Thailand\%20in\%202017

[25] Morton, L.W. (2020) Working toward Sustainable Agricultural Intensification in the Red River Delta of Vietnam. Journal of Soil and Water Conservation, 75, 109A-116A. https://doi.org/10.2489/jswc.2020.0304A

[26] UN FAO (United Nations Food Agriculture Organization) (1997/1998) Annex 2: Food Security in Southeast Asia. http://www.fao.org/3/ab981e/ab981e0b.htm

[27] Goscha, C. (2016) Vietnam. A New History. Basic Books, New York.

[28] Olson, K.R. and Morton, L.W. (2019) Long-Term Fate of Agent Orange and Dioxin TCDD Contaminated Soils and Sediments in Vietnam Hotspots. Open Journal of Soil Science, 9, 1-34. https://doi.org/10.4236/ojss.2019.91001 
[29] Quazi, S., Datta, R. and Sarkar, D. (2011) Effects of Soil Types and Forms or Arsenical Pesticide on Rice Growth and Development. International Journal of Environment Science and Technology, 8, 445-460. https://doi.org/10.1007/BF03326231

[30] Singh, A.K. and Rai, S. (2017) Arsenic Pollution: An Environmental Problem. Indian Journal of Scientific Research, 15, 51-53.

[31] Islam, S., Rahman, M.M., Islam, M.R. and Naidu, R. (2017) Effect of Irrigation and Genotypes toward Reduction in Arsenic Load in Rice. Science of the Total Environment, 609, 311-318. https://doi.org/10.1016/j.scitotenv.2017.07.111

[32] Talukder, A.S., Meisner, C.A., Sarkar, M.A.R. and Islam, M.S. (2011) Effect of Water Management, Tillage Options and Phosphorus Status on Arsenic Uptake in Rice. Toxicology and Environmental Safety, 74, 834-839. https://doi.org/10.1016/j.ecoenv.2010.11.004

[33] Erban, L.E., Gorelick, S.M., Zebker, H.A. and Fendorf, S. (2013) Release of Arsenic to Deep Groundwater in the Mekong Delta, Vietnam, Linked to Pumping-Induced Land Subsidence. PNAS, 110, 13751-13756. https://doi.org/10.1073/pnas.1300503110

[34] Nguyen, P.K. (2008) Geochemical Study of Arsenic Behavior in Aquifer of Mekong Delta, Vietnam. A Dissertation a Degree of Doctor of Engineering in Kyusha University.

[35] Lievremont, D., Bertin, P. and Lett, M.C. (2009) Biochemical Cycle, Microbial Metabolism and Bio-Treatment Processes. Biochimie, 91, 1229-1237. https://doi.org/10.1016/j.biochi.2009.06.016

[36] Schroeder, H.A. and Balassa, J.J. (1966) Abnormal Trace Metals in Man. Journal of Chronic Diseases, 19, 85-106. https://doi.org/10.1016/0021-9681(66)90152-4

[37] Berg, M., Stengel, C., Viet, P., Sampson, M., Leng, M., Samreth, S. and Fredericks, D. (2007) Magnitude of Arsenic Pollution in the Mekong and Red River Deltas-Cambodia and Vietnam. Science of the Total Environment, 372, 413-425. https://doi.org/10.1016/j.scitotenv.2006.09.010

[38] Radke, B., Jewell, L., Piketh, S. and Namiesnik, J. (2014) Arsenic-Based Warfare Agents: Production, Use and Destruction. Critical Reviews in Environmental Science and Technology, 44, 1525-1576. https://doi.org/10.1080/10643389.2013.782170

[39] Vilensky, J.A. (2005) Dew of Death. The Story of Lewisite, America's World War I Weapon of Mass Destruction. Indian University Press, Bloomington.

[40] Agency for Toxic Substances and Disease Registry (ATSDR) (2007) Toxicological Profile for Arsenic. U.S. Department of Health and Human Services.

[41] Brooks, W.E. (2007) Mineral Commodity Summaries. Arsenic. U.S. Geological Survey.

[42] Brammer, H., Ravenscroft, P. and Richards, K. (2009) Arsenic Pollution: A Global Synthesis. Wiley-Blackwell. A John Wiley and Sons Ltd.

[43] Schwarcz, J. (2018) What Is the Difference between Organic and Inorganic Arsenic? Office for Science and Society.

[44] National Academy of Sciences (NAS) (1974) The Effects of Herbicides in South Vietnam. Part A Summary and Conclusions. National Academy of Sciences. Committee on the Effects of Herbicides in Vietnam, Division of Biological Sciences, Assembly of Life Sciences, National Research Council. Washington DC.

[45] Darrow, R.A., Frank, J.R., Martin, J.W., Demaree, K.D. and Creager, R.A. (1971) Field Evaluation of Desiccants and Herbicide Mixtures as Rapid Defoliants. Tech- 
nical Report 114. Plant Sciences Laboratories. Fort Detrick, Frederick, MD. The Defense Documentation Center, Accession Number AD 880685.

[46] Sypo, T. (2004) Korea DMZ Vets and Agent Orange. January 2004 Issue of VFW Magazine.

[47] Harte, J., Holdren, C., Schneider, R. and Shirley, C. (1991) Toxic A to Z. A Guide to Everyday Pollution Hazards. University of California Press, Berkeley.

[48] Altug, T. (2003) Introduction to Toxicology and Food. CRC Press, New York. https://doi.org/10.1201/b13578

[49] Ahuya, S. (2008) Arsenic Contamination of Groundwater. Wiley \& Sons Inc., Hoboken. https://doi.org/10.1002/9780470371046

[50] Young, L. (2009) The History, Use, Disposition and Environmental Fate of Agent Orange. Springer, Berlin, 38-39. https://doi.org/10.1007/978-0-387-87486-9

[51] Pham, Q.B. (1995) Environmental Pollution in Vietnam: Analytical Estimation and Environmental Priorities. Trends in Analytical Chemistry, 14, 383-388. https://doi.org/10.1016/0165-9936(95)90916-B

[52] Young, A.L. (2006) The History of the U.S. Department of Defense Programs for the Testing, Evaluation and Storage of Tactical Herbicides. Office of the Under Secretary of Defense William Van Houten, Washington DC.

[53] Stellman, J.M., Stellman, S.D., Christian, R., Weber, T. and Tomasalo, C. (2003) The Extent and Patterns of Usage of Agent Orange and the Other Herbicides in Vietnam. Nature, 422, 681-687. https://doi.org/10.1038/nature01537

[54] Buckingham, W.A. (1982) The Air Force and Herbicides in Southeast Asia 1961-1971. Office of Air Force History, United States Air Force, Washington DC.

[55] Greenfield, G. (2004) Agent Blue and the Business of Killing Rice. https://www.contercurrents.org.us-greenfield180604.htm/

[56] Hoylman, L. (2015) Agent Blue: Arsenic-Laced Rainbow Herbicide. The VVA, Silver Spring. http://vvaveteran.org/35-3/35-3 agentblue.html

[57] Fox, R.P. (1979) Air Base Defense in the Republic of Vietnam 1961-1973. Office of Air Force History, United States Air Force, Washington DC. https://doi.org/10.21236/ADA081453

[58] Nakamura, G. (2007) Defoliation during the Vietnam War. In: Extreme Conflict and Tropical Forests, Springer, Berlin, Chapter 9, 149-158. https://doi.org/10.1007/978-1-4020-5462-4_9

[59] Watson, A., Van Hook, R. and Reichle, D. (1976) Toxicity of Organic and Inorganic Arsenicals to an Insect Herbivore. Environmental Science and Technology, 10, 356-359. https://doi.org/10.1021/es60115a001

[60] House of Representatives (1980) Agent Orange: Exposure of Vietnam Veterans Hearing before the Sub-Committee on Oversight and Investigation of the Committee on Interstate and Foreign Commerce, 96th Congress, 2nd Session. September 25 .

[61] Institute of Medicine (1994) Veterans and Agent Orange: Health Effects of Herbicides Used in Vietnam. Committee to Review the Health Effects in Vietnam Veterans of Exposure to Herbicides. National Academies Press, Washington DC, 89-90.

[62] Olson, K.R. and Tharp, M. (2020) How Did the Passaic River, a Superfund Site near Newark, New Jersey, Become an Agent Orange Dioxin TCDD Hotspot? Journal of Soil and Water Conservation, 75, 33A-37A. https://doi.org/10.2489/jswc.75.2.33A

[63] Galston, A.W. (1972) Science and Social Responsibility: A Case Study (PDF File). Annals of New York Academy of Sciences, 196, 223-235. 
https://doi.org/10.1111/j.1749-6632.1972.tb21231.x

[64] Perce, J. (2008) Arthur Galston, Agent Orange Researcher. Is Dead at 88. New York Times, 06-23-2008.

[65] Wipedia: The Free Encyclopedia 92020. Waging Peace in Vietnam. Wikimedia Foundation, St. Petersburg.

[66] Cohen, S.K. (2003) Arthur W. Galston Oral History Interview. California Institute of Technology. Archives and Special Collections. Identifier: 2003-00199. http://collections.Archives, Caltech.edu/repositories/2/accessions/3291

[67] U.S. Food \& Drug Administration (2020) Arsenic-Based Animal Drugs and Poultry. https://fda.gov/animal-veterinary/product-safety-information/arsenic-based-animal -drugs-and-poultry

[68] Bencho, V. and Foong, F.Y.L. (2017) The History of Arsenical Pesticides and Health Risks Related to the Use of Agent Blue. Annual of Agricultural and Environmental Medicine, 24, 312-316. https://doi.org/10.26444/aaem/74715

[69] Thuy, M.L. (2012) Arsenic Contaminated in Groundwater in Vietnam. Pomona College, Claremont.

[70] Juen, L.L., Aris, A.Z., Ying, L.W. and Harris, H. (2014) Bio-Concentration and Translocation Efficiency of Metals in Paddy (Orzya sativa): A Case Study from Alor Setar, Kedah, Malaysia. Sains Malaysiana, 43, 521-528.

[71] Aide, M., Beighly, D. and Dunn, D. (2016) Arsenic in the Soil Environment: A Soil Chemistry Review. International Journal of Advance Agricultural Research, 11, 1-28.

[72] Lei, M., Tie, B., Williams, P.N., Zheng, Y. and Hung, Y. (2011) Arsenic, Cadmium and Lead Pollution and Uptake by Rice (Oryza sativa L.) Grown in Green House. Journal of Soils and Sediments, 11, 115-123. https://doi.org/10.1007/s11368-010-0280-9

[73] Chuc, T.M. (2018) “Agent Blue” from Invisible Light. Permission of Many Voices Press, Chicago.

[74] Tomasallo, C. (2003) The Extent and Patterns of Usage of Agent Orange and Other Herbicides in Vietnam. Nature, 422, 681-687. https://doi.org/10.1038/nature01537

[75] Ly, T.M. (2012) Arsenic Contamination in Groundwater in Vietnam: An Overview and Analysis of Historical, Cultural, Economic, and Policy Parameters in Success of Various Mitigation Options. Pomano College, Claremont.

[76] Powell, E. (2017) Have You Heard of VA Disability Claims for Agent Blue? https://info.bluesteinattorneys.com/have-you-heard-of-va-disability-claims-for-age nt-blue

[77] Suriyagoda, L.D.B., Dittert, K. and Lambers, H. (2018) Mechanism of Arsenic Uptake, Translocation and Plant Resistance to Accumulate Arsenic in Rice Grains. Agriculture, Ecosystems and Environment, 253, 23-37. https://doi.org/10.1016/j.agee.2017.10.017

[78] Paltseva, A., Cheng, Z., Deeb, M., Groffman, P.M., Shaw, R.K. and Maddaloni, M. (2018) Accumulation of Arsenic and Lead in Garden-Grown Vegetables: Factors and Mitigation Strategies. Science of the Total Environment, 640-641, 273-283. https://doi.org/10.1016/j.scitotenv.2018.05.296

[79] Mirza, N., Mahmood, Q., Shah, M.M., Pervez, A. and Sultan, S. (2014) Planta as Useful Vectors to Reduce Environmental Toxic Arsenic Content. The Scientific World Journal, 2014, Article ID: 921581. https://doi.org/10.1155/2014/921581

[80] USAID (United States Agency for International Development) (2016) Environmental Assessment of Dioxin Contamination at Bien Hoa Airbase. Environmental 
Assessment in Compliance with 22 CR 216-Final, 870 p.

[81] Westing, A.H. (1972) Ecological Effects of the Vietnam War. Journal of the American Institute of Planners, 38, 297-307. https://doi.org/10.1080/01944367208977626

[82] Young, A.L. (1990) A White House Perspective on Risk Assessment and Risk Communications. Science of the Total Environment, 99, 223-229.

https://doi.org/10.1016/0048-9697(90)90152-K 